$$
\text { الفنون التشكيلية في مصر من الحداثة إلى مابعدها }
$$

Egyptian plastic Arts from Modernity to Post modernity

reem22737@hotmail.com

كلية الفنون الجميلة، جامعة حلوان

د. ريم عاصم عبد الحق صالح

مرت الفنون التثكيلية في مصر بمراحل متعددة منذ نشأتها في بدايات القرن العشرين وارتبطت بثكل أو بآخر بالقوالب

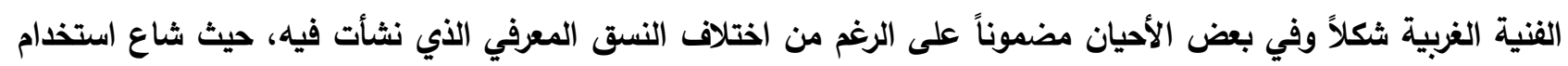

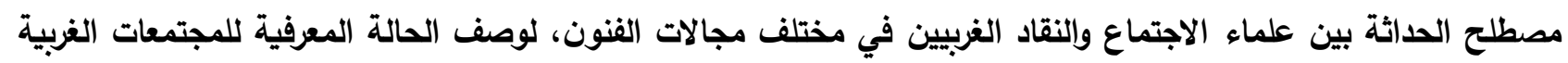
في نهاية القرن التاسع عشر وبداية القرن العشرين، ثم جاء مصطلح مابعد الحداثة ليثكل أزمة فى الأوساط المعرفية العربية

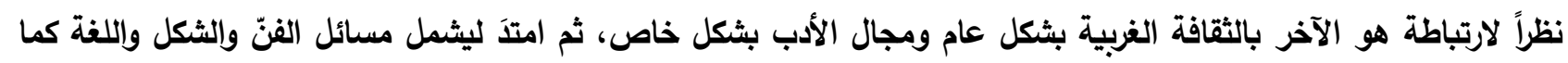
جاء فى دراسات أهم مؤرخيه. يُستهل البحث بتعريف موجز لأهم سمات الفترتين محل الدراسة ثم استعراض أفكار المفكرين

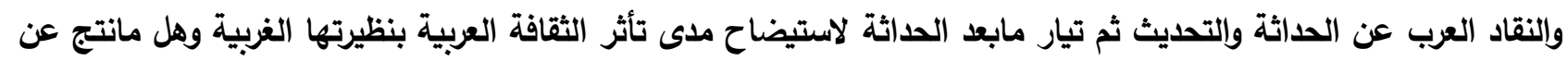
هذا التأثر من أثكال فنية (خاصة في مصر محل الدراسة) جائت محاكية للنمط الغربي، أم انها جائت معبرة عن تجارب واقعنا

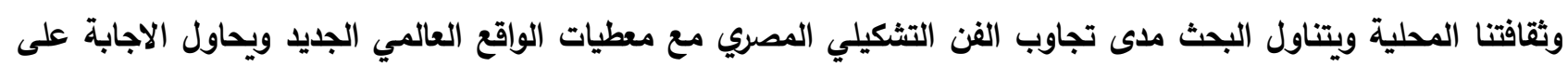

بعض التساؤلات الخاصة بالحدود الزمنية للمراحل الفنية للفن التشكيلي المصري من خلال تناول نماذج من من الأعمال الفنية. الكلمات المفتاحية: الحداثة - مابعد الحداثة - الفن المصري الحديث

Egyptian plastic arts have undergone various stages since its inception in the early 20th century and have been linked in one way or another to Western art forms and sometimes in content, despite the differences of cognitive pattern in which they originated, Where the term modernity was used among sociologists and Western critics in various art fields, to describe the cognitive state of Western societies at the end of the nineteenth century and the beginning of the twentieth century. The term post modernism formed a crisis in the Arab cognitive circles because of its intertwined with the Western culture in general and the field of literature in particular, then it extended to include the issues of art and form and language, as stated in the studies of its most important historians.The study begins with an ideas review of the of Arab intellectuals and critics about modernity and modernize and then the postmodernism stream to clarify the extent to which Arab culture is influenced by its Western counterparts. Was it influenced by artistic forms that have become a simulation of the Western style, or it reflects the experiences of our reality and local culture (especially in Egypt) . Also, research deals with the extent to which Egyptian plastic arts respond to modernism and post modernism art trend to answer some questions concerning the time limits of the artistic stages of modern Egyptian art and study some of them. 
نشأت حركة الفنون التشكيلية في مصر مع بداية القرن العشرين تقريباً أي منذ مايزيد عن المائة عام تزامناً مع حركات التنوير

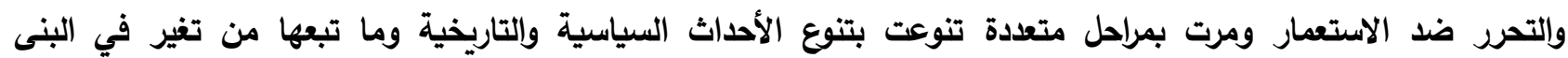

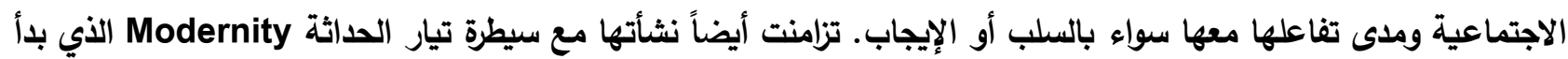
في الغرب مع عصر التنوير مع نهاية القرن الثامن عشر واستمر حتى بدايات القرن العشرين ثم واكبت تيار مابعد الحداثة Post Modernity المجتمعات الغربية التي يمكن وصفها بالحديثة أو بالمتطورة -إن جاز التعبير - والتي سيستعرض البحث لاحقاً معاييرها وشروطها.

وما بين الأصالة والتغريب أو التراث والتجديد ظل الفن التشكيلي المصري يتأرجح منذ نثأته بين أشكال وقوالب فنية تحتفي

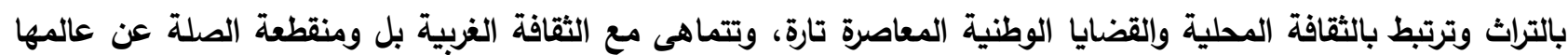

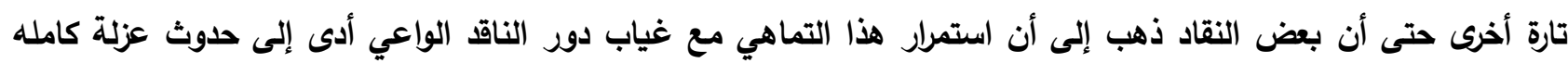
للحركة الفنية في مصر عن المجتمع في العصر الحالي، تلك العزلة التي لم تحدث منذ نشأة حركة الفن التثكيلي المصري.

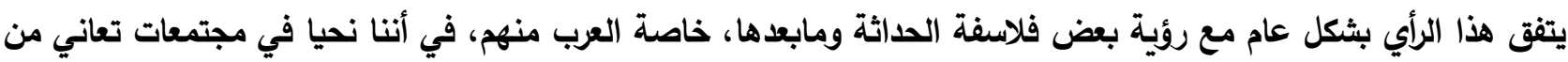

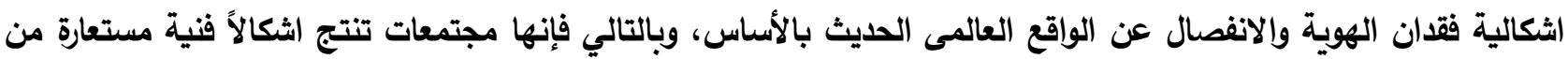

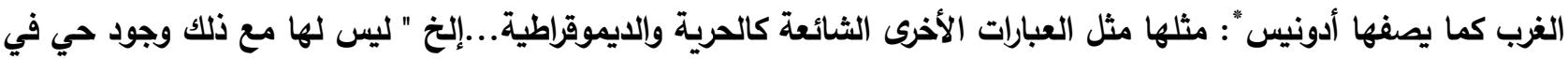

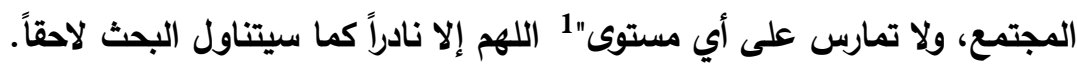
يُستهل البحث باستعراض بعض ولارئ عارئ أراء المفكرين والنقاد الغربيين وكذلك العرب عن الحداثة كفلسفة والتحديث كفعل مواكب لها، ثم تيار مابعد الحداثة، والذى هيمن على الثقافة الغزبية قرابة الخمسون عاماً الأخيرة من القرن العشرين وهى بصدد تجاوزة الآن الي مايعرف بمرحلة "بعد مابعد الحداثة" في محاولة لاستيضاح مدى تأثر الثقافة العربية بنظيرتها الغربية وهل مانتج عن هذا التأثر من أثكال فنية (خاصة في مصر محل الدراسة) جائت فقط محاكية للنمط الغربي، أم انها تعبر عن تجارب واقعنا وثقافتنا المحلية ويحاول الاجابة على بعض التساؤلات الخاصة بالحدود الزمنية للمراحل الفنية للفن التثكيلي المصري من خلال تناول نماذج من الأعمال الفنية، ومدى مواكبتها لتلك التيارات الفكرية فى ظل ثقافة العولمة ومانتج عنها من تقارب واختلاط للانساق الفكرية والفنية، بإعتبار أن العمل الفني هو ناتج حضاري ومحصلة لمجموعة من التفاعلات على مستويات عدة من الثقافة والسياسة والتاريخ وغيرها وبالتالي لابد وأن يختلف باختلاف الأرضية الثقافية والاجتماعية التى نثأ فيها،

$$
\text { بوصف الفن ظاهرة سسيولوجية بالأساس. }
$$

وهنا تتجلي أهمية تساؤل تيري ايغلتون* Terry Eagleton في طرحة عن مرحلة مابعد الحداثة، التساؤل الذي يصلح من

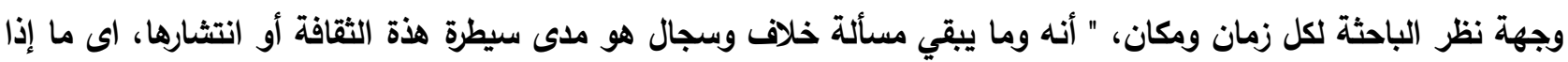

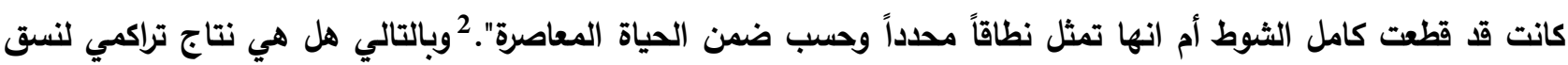

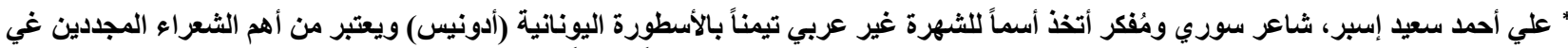

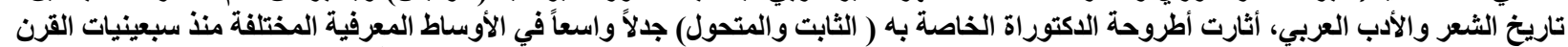

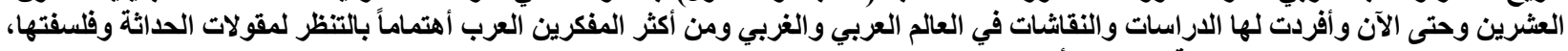

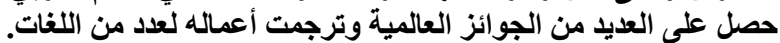

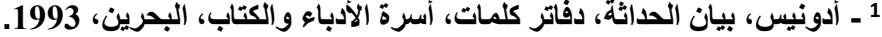

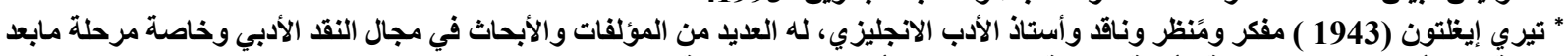

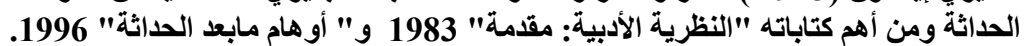
2ـ محمد سبيلا وعبد السلام بنعبد العالي، مابعد الحداثة 1 تحديدات، سلسة دفاتر فلسفية، نصوص مختارة ، دار توبقال للنشر، الدار البيضاء، المغرب، 
معرفي ثقافي خاص بمجتمع محدد؟ (وهو هنا المجتمع المصري) أم أنها مرحلة منفصلة تماماً ونتاج لواقع عالمي جليد لعبت

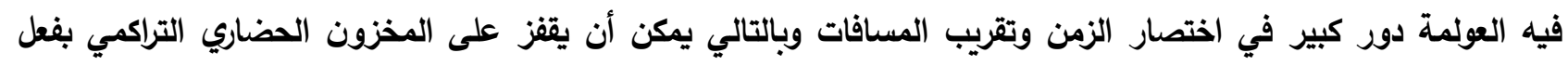

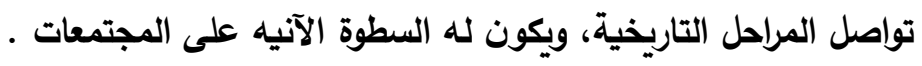

مشكلة البحث:

- هل الحركة التشكيلية المصرية منذ نشأتها تعبر عن نسق ثقافي ومعرفي شامل أم انها مجرد ابداعات فردية تسبح في

جذر منفصلة ؟ - - هل هناك مراحل محدة مرت بها الحركة التثكيلية المصرية منذ نثأتها وحتى نهاية الثمانينيات يمكن مقارنتها باتجاهات الفن العالمي في نفس الفترة ؟ هراد - - هل تُعد أعمال الفن التشكيلي المصري ترديد لأصداء ثقافة الحداثة ومابعدها بمفهومها الغربي أم أنها تعبر عن حداثتا العربية وإلمصرية بثكل خاص؟ العن أهمية البحث: - - تحديد المراحل والاتجاهات الخاصة بالفن المصري الحديث منذ نشأته وحتى نهاية الثمانينيات. - التركيز على مظاهر الحداثة ومابعد الحداثة في أعمال الفن التثكيلي المصري. - رصد وتحليل مدى ارتباط الفنون التثكيلية المصرية بالثقافة المحلية والعالمية في الفترة محل الفئل الدراسية. فروض البحث: - - ماضترض البحث أن تياري الحداثة ومابعد الحداثة (Post Modernism) المميزين للواقع الثقافي العالمي الحديث والمعاصر يعبران عن واقع الثقافة المصرية وعن تجارب واقعنا وقضايانا المحلية الآن.

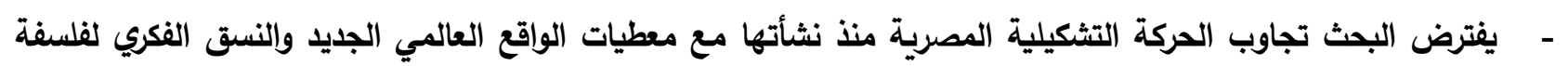
الحداثة ومابعدها. - - يفترض البحث أن مضمون أعمال الفن المصري الحديث، تختلف باختلاف الأرضية الثقافية والاجتماعية التى نشأت فيها

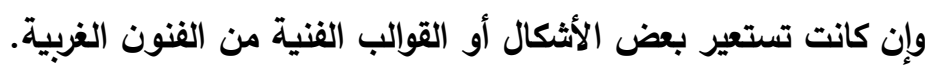
حلود البحث : الحد المكاني / مصر م م الحد الزماني / نهاية القرن التاسع عشر إلى نهاية القرن العشرين.

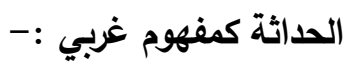
يُعد مفهوم الحداثة Modernity من اهم مفاهيم الفكر الغربي في العصر الحالي** مقات شاع استخدامة في الكتابات النقدية

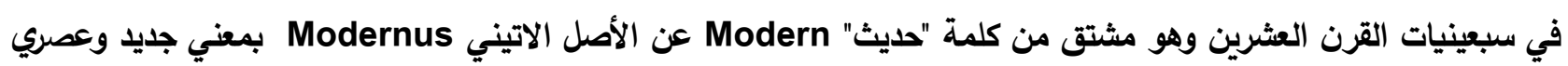
بالإحالة الى عصره، وفي العربية حداثة بمعنى جدًة وهي (اسم) : مصدر حَدُثَ، دلالة على معاصرة الآيني الثكل الأدبي أو الفني 
وتبنيه أشكال وأساليب جديدة ثائرة على القديم وأحياناً نقيض أو ردة فعل على ماسبقه وهي تثمل حقول متعددة للنشاط

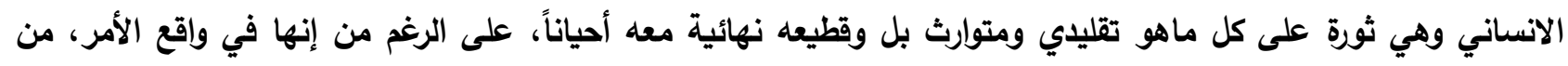

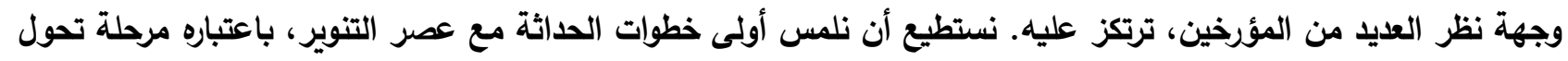
تاريخية وحداً فاصلاً بين الماضي والحاضر في نهاية القرن الثامن عشر وبداية القرن التاسع عشر تزامناً مع قيام الثورة الصناعية في إنجلترا وكذلك الثورة الفرنسية كما يرى هيجل Hegel * *32. تلك الفترة التي حققت فيها المجتمعات الأوروبية وخاصة البرجوازية أعلى نجاحاتها على المستوى الفكري والمادي. هناك العديد من الفلاسفة اللذين يتلمَسون أولى خطواتها مع

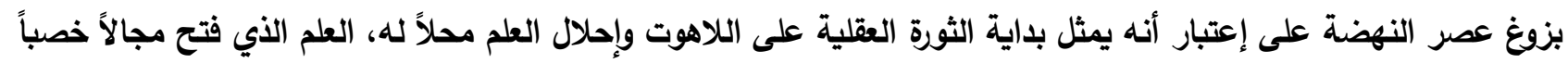

للثك والتجربب ولتأكيد النزعة الفردية على كافة الأصعدة وبدأ معه مايعرف بعصر العقلانية Rationalism.

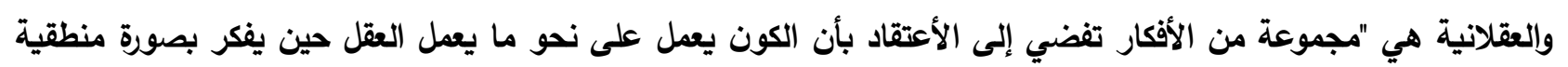
وموضوعية"4 وهي الركيزة الفلسفية لمشروع الحداثة والطريق إلى معرفة الحقيقة. تلك الأفكار التي اتاحت للانسان الغربي في لإني

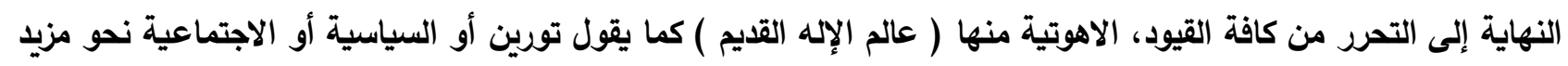

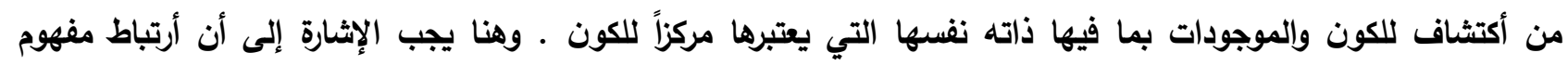

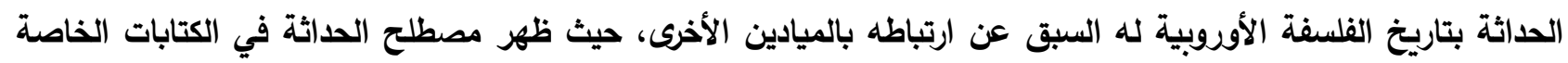

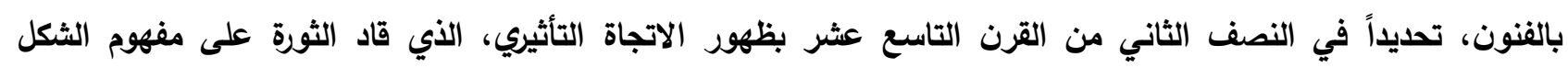
ومكانته في العمل الفني وانتصر عليه في المقابل للتجربة الجمالية والثعورية أداءياً وحسياً، الأمر الذي يُعد تحولاً راديكالياً ومدخلاً لجميع الاتجاهات والمدارس الفنية الاحقة وحتى الآن. فحين فقد الثكل مكانته كمصدر للالهام (المقصود هنا مشاهد وعناصر الطبيعة الحية) فقد معه الاتجاة الأكاديمي الكلاسيكي مكانته وهو القائم على محاكاتها وتفتحت آفاق جديدة للتعبير بثتى الطرق وشتى الخامات وحدثت المزاوجة بين سياقات الفن المختلفة تدريجياً إلى أن وصلنا إلى مرحلة مابعد الحداثة الطئة . وهنا يجدر بنا الإثارة إلى أن بداية استخدام ودلالة اللفظ (الحداثة) في عالم الفنون كمصطئح في العصر الحالي، يثير إليها بوصفها مرحلة زمنية طويلة تضم حركات فنية متعددة بدأت مع منتصف القرن الثامن عشر واستمرت حتى منتصف القرن القرن العثرين وكمفهوم يضم شتى أنواع التجريب والنقد الذاتي والخروج عن المألوف على مدار العصور في الفكر الغربي .

مابعد الحداثة : إن مابعد الحداثة هي التطور الحتمي للحداثة كما يرى أغلب المفكرون الغربيون ومما لا شك فيه أن النزاع الفكري الذي نثب بين الأدباء في فرنسا وانجلترا مع نهاية القرن السابع عشر وبداية القرن الثامن عثر، بين أفضلية ما بلغته الثقافة الكلاسيكية (تقافة الأقدمين) على الثقافة العقلانية أو (تقافة المحدثين)- ذلك النزاع، هو الذي بشَّرَ ومهَّه لمفهوم - مابعد

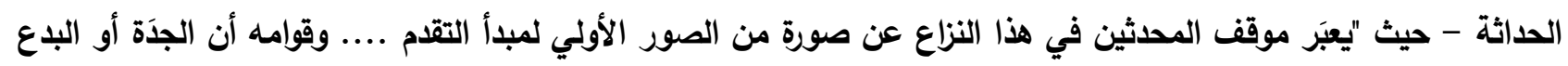

* يتمايز مفهوما الحداثة Modernity عن مفهوم التحديث Modernization في اللغتين الفرنسية والإنكليزية .فالحداثة هي موقف عقلي تجاه

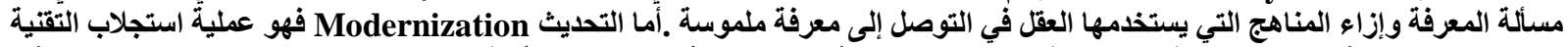

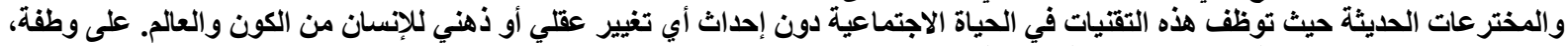
مقاربات في مفهومي الحداثة ومابعدها، مدونة الحداثة ومابعدها، 18 / يوليو 2016. http://www.aljabriabed.net/1_10 table.htm ج*** جورج هيغل ( 1770 - 1831 ) من أهم الفلاسفة الألمان ويعتبر من مؤسسي المثالية الألمانية ومن دعاة المنهج الجلئي وآخر بناة المشاريع

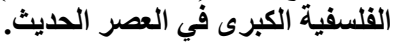

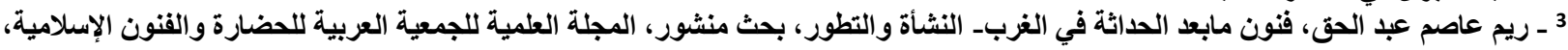

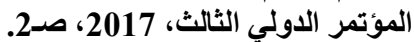

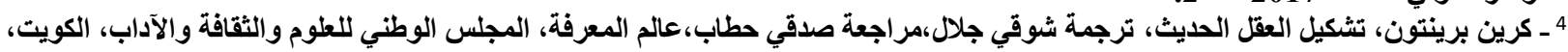


ليس هلوسة ولاتراجعاً بل جهاً طبيعياً ضمن خطة شاملة"5 . هذا الجهد الذي تنامى وتعاظم، نتج عنه في النهاية تيار مابعد

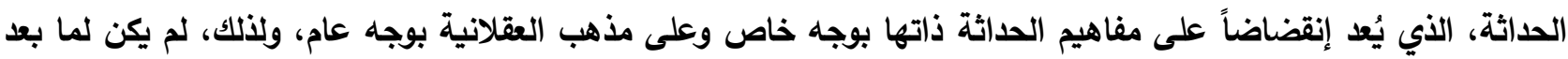
الحداثة وجود، إلا بوجود الحداثة ذاتها، حيث مرت الثعوب الغربية بتحولات فكرية كبرى نتيجة الأزمات السياسية والاقتصادية التي هددت وجودها، بداية من نذر قيام الحربين العالميتين الأولى والثانية، ومروراً بأحداثهما والتي انهارت معهما الثوابت

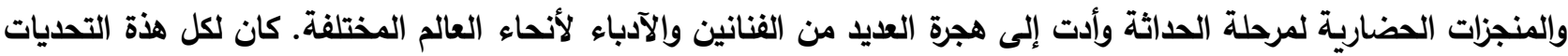
انعكاس على الثقافة والفنون بثكل عام وساعد على تأكيد لامركزيتهما الأوروبية حيث ظهرت على السطح فنون وثنقافات لاتهاء

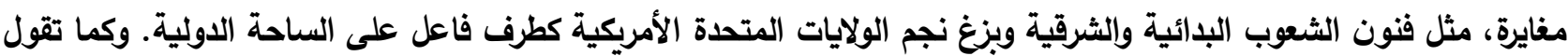
برندا مارشال Brenda K. Marshall إن مابعد الحداثة "هي طريقة للتفكير أكثر منها توجه يبحث عن تفسير" سماتها عدم التحديد أو فقدان الأطر التي يمكن أن تحتويها، وهو مصطلح خلافي منذ نثأته وحتى الوقت الراهن الهن.

شمل المصطلح الثقافة الغربية بكافة فروعها في بداية الأمر بثكل عام ومجال الأدب بثكل خاص، ثم امتًَ ليشمل مسائل الفنّ وإلثكل واللفة كما جاء فى كتاب "أدب الصمت" لأحد أهم مؤرخيه، ايهاب حسن " والذي يتناول الأدب مابعد الحدائثي ومظاهر التحول الجديد ليعلن "الرفض التام للتاريخ والحضارة الغربيين، ولصورة الإنسان كمقياس للأثشياء جمعاء"7. وقيمة الإنسان هنا -في الغرب- بما يمثله منذ عصر النهضة بوصفه أعظم مثال لانجازات الإله على الأرض ومحور ثقافة الانسانيين وما حققته من خطوات تالية على طريق التنوير، قد تضائلت، كما تميزت تلك الثقافة بسرعة وتدفق الأفكار والتجارب وفقدان المركزية الأوروبية التي ميزت عصر العقلانية الذي سبقها، وكذلك اقصاء بعض مظاهرها والاحتفاء ببعضها الآخر ثم الاحتفاء بنقيضهما معاً وعدم وجود مباديء محددة للقياس أو للقبول والرفض وطغيان الجدَة على المضمون ... إلخ هُهن

إن مابعد الحداثة هي مفهوم شامل وعام لا يختص بعالم الثقافة والفن فقط وإنما هى رؤية جديدة لعالم جديد سيطرت فيه التكنولوجيا وسرعة تدفق المعلومات وسرعة الاتصال على جميع مناحي الحياة وقد تأثرت بالفلسفة العدمية لـ نيتثه ** Friedrich Nietzsche( 1900 - 1844 يفقد قيمه الراسخة ومثله العليا فقط، بل إنعدمت قيمة وجوده ـ كذلك الفلسفة الوجودية لجان بول سارتر *** (1905 Jean-Paul Sarter (1980 (الداعمة لحربية الفرد ومسؤليته عن أفعاله وبالتالي عن ما سيأول إليه، وقد كان لزيارة

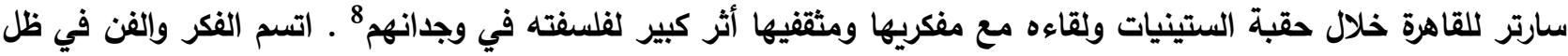

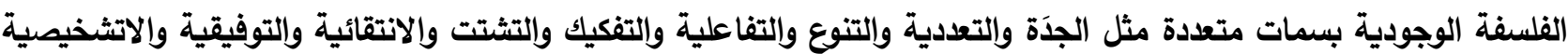
وطغيان الثقافة الثعبية والدمج بين الأجناس الأدبية والأساليب الفنية...الخ. فما بعد الحداثة هي ثقافة تنعم بقدر كبير من

ـ - كرين برينتون، تثكيل العقل الديث، مرجع سبق ذكره، 153.

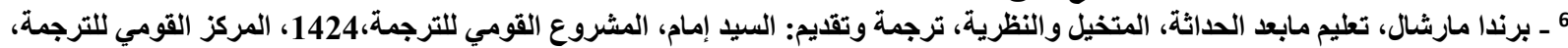

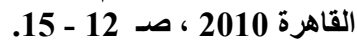

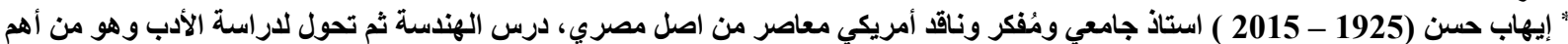

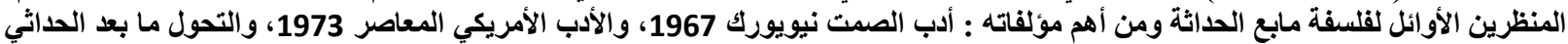
1987 http://nomene.blogspot.com.eg/2015/03/blog-post.html 7 - إيهاب حسن، أدب الصمت، ترجمة: محمد عيد إبراهيم، مدونة جورج باتاي، مارس 2015.

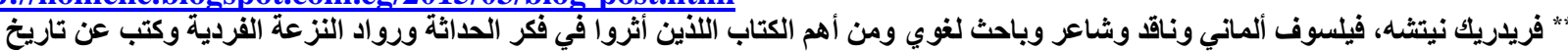

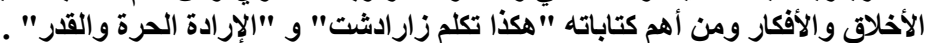

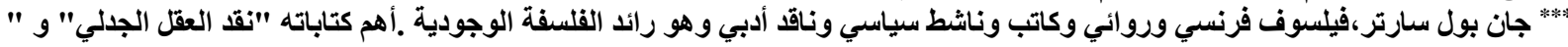

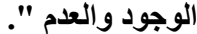
8 ـ هبة عزت الهواري، تحولات التشكيل المصري المعاصر (1967 - 2011)، دراسة، سلسلة الكتاب الأول 138 ،المجلس الأعلى للثقافة، 2015، صـ 
الحرية وتتوغل في العديد من أنثطة الحياة اليومية مُثكلة خليط متجانس ومتنافر في ذات الوقت، يعكس روح العصر .9 إذاً

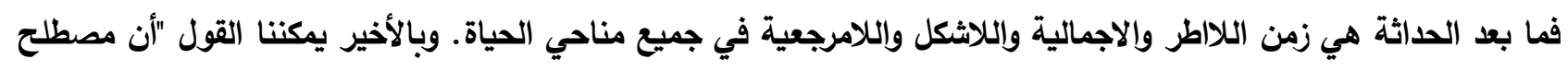
الحداثة ومابعد الحداثة أطلق لاختزال حقبة تاريخية واسعة في كلمة واحدة محددة قابلة ولابلة للتفسير والاجتهاد 10 ".

الحداثة وما بعدها من منظور ثقافتنا العببية وعلاقتها بالغرب:

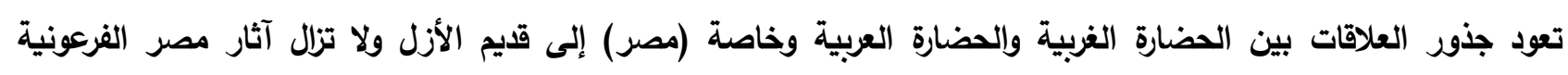

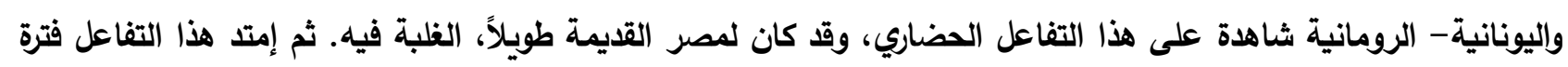

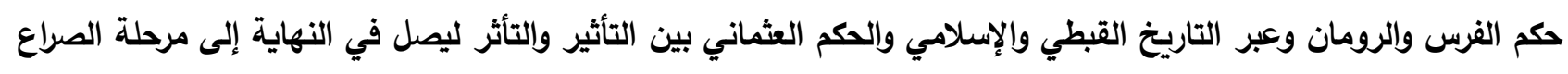

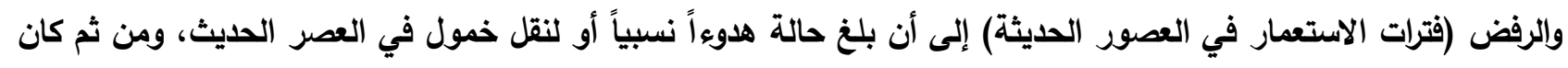

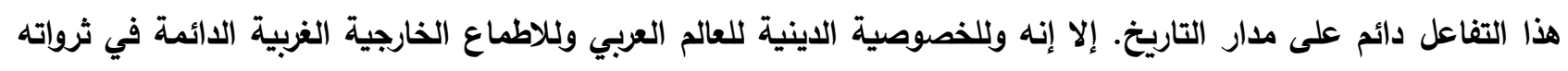

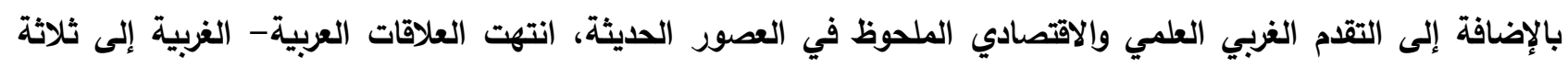

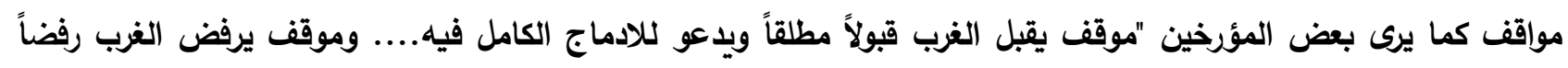

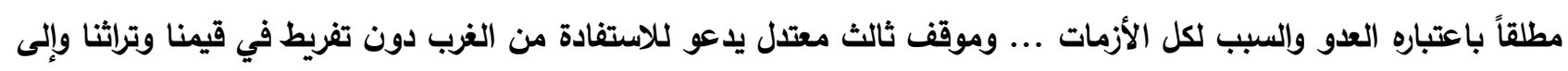

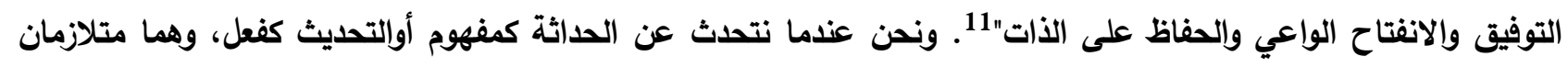

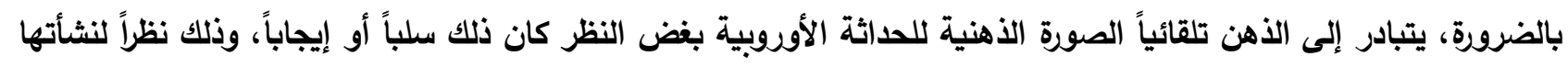

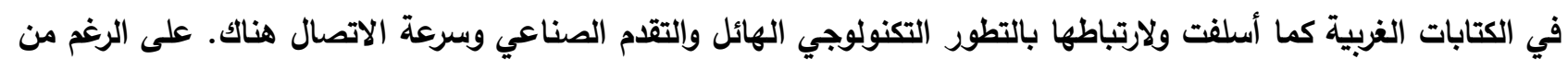

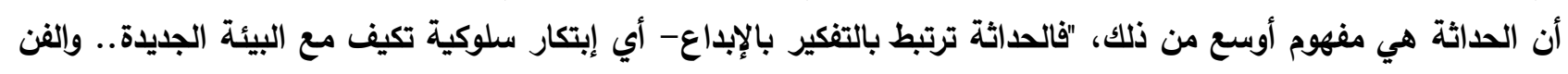

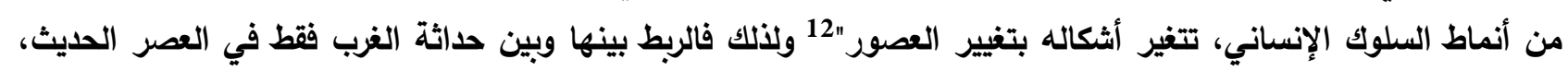
هو طرح يحمل تحيّز لجانب الغرب.

ومما لاثك فيه أن تناول خطاب الحداثة ومابعدها قد شكل ازمة في الاوساط المعرفية العببية وفتح مجالاً واسعاً للجدل

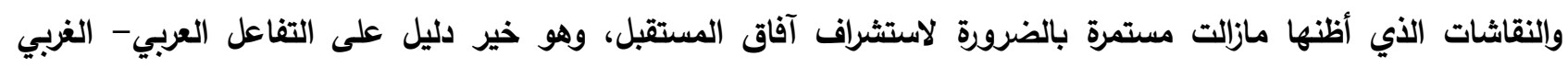

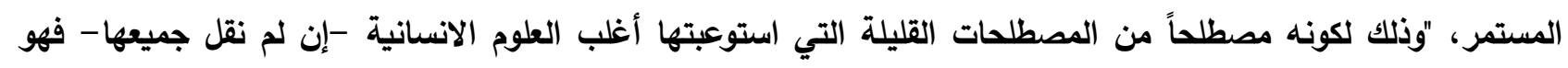

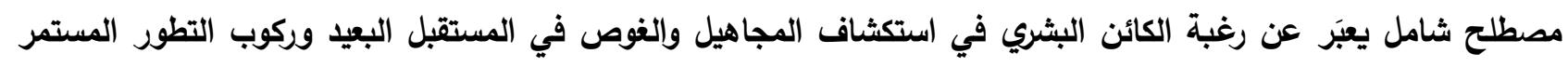

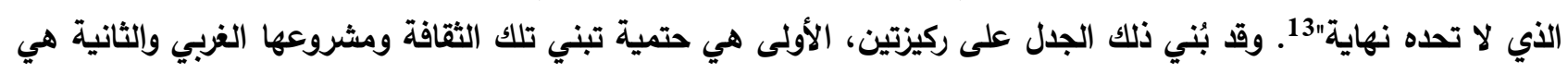

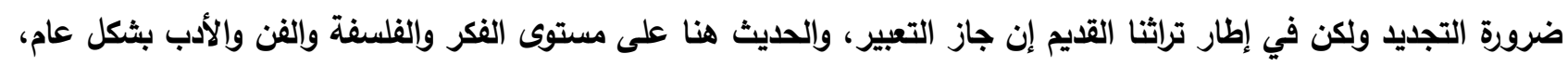

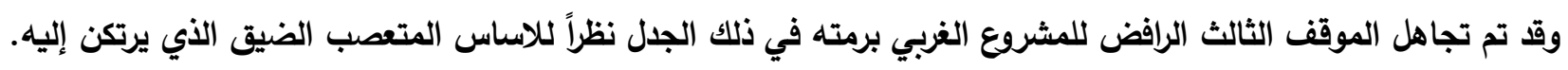

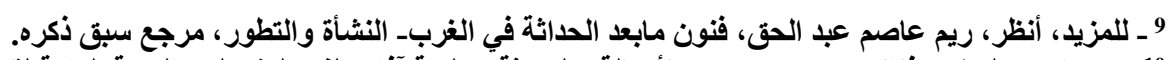

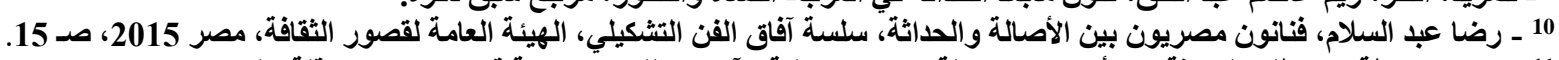

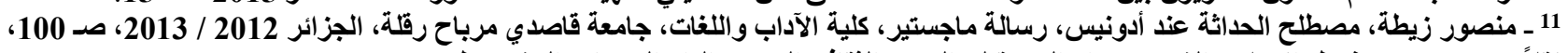

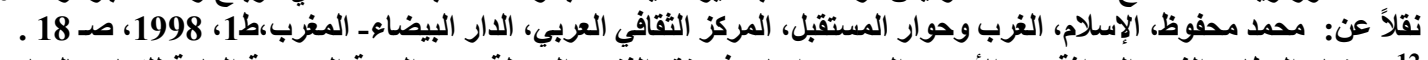

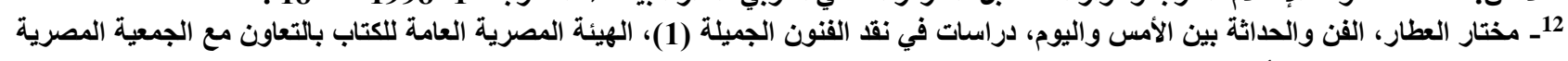

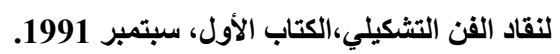

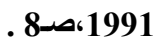
13 ـ منصور زيطة، مصطلح الحداثة عند أدونيس، مرجع سبق ذكرة، صـ 4. 
إن من أهم المفكرين العرب الذين تبنوا مشروع الحداثة ومقولاتها، هو أدونيس الذي يقول عنها وخاصة في مجال الأدب" "أن النهائ

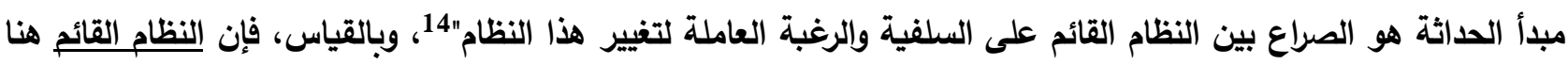

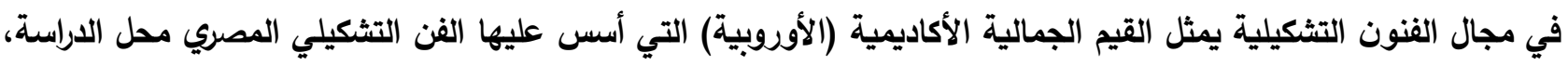

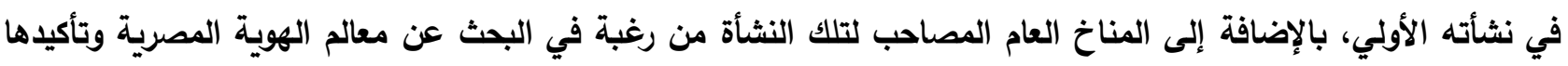

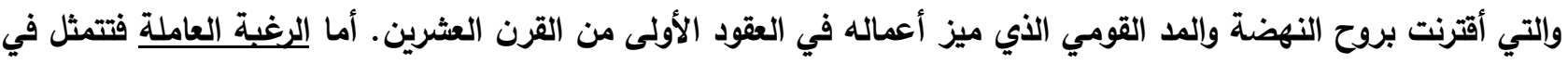

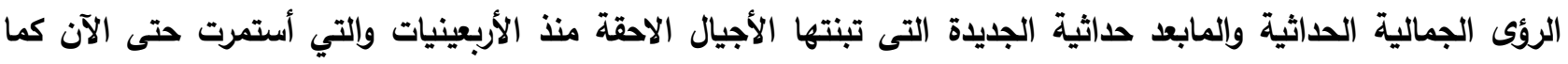

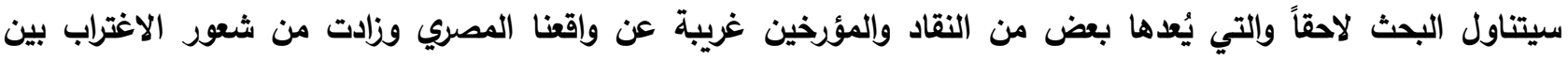

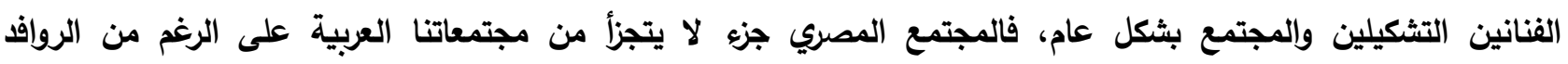

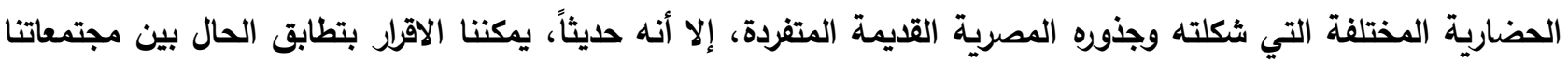

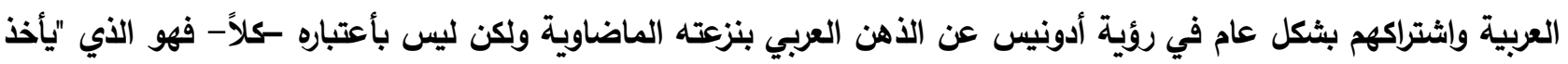

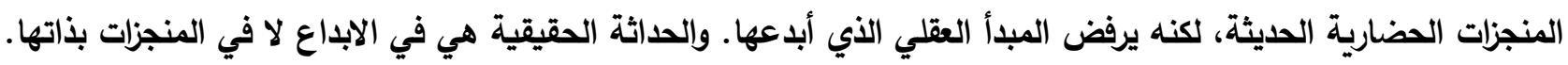

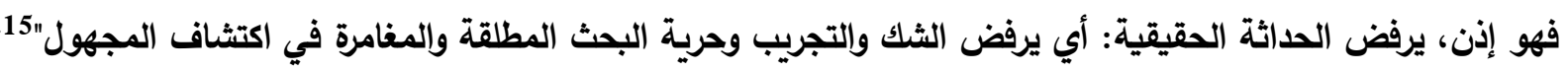

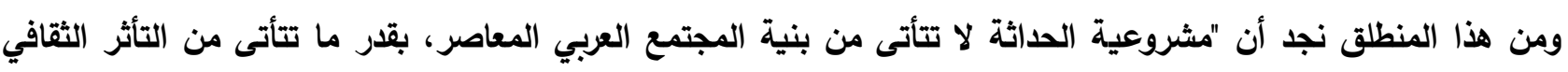

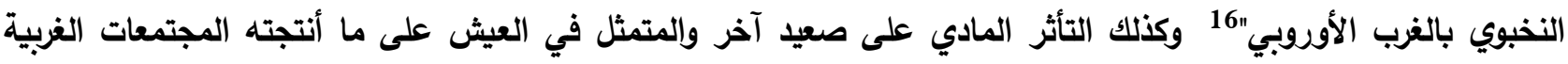

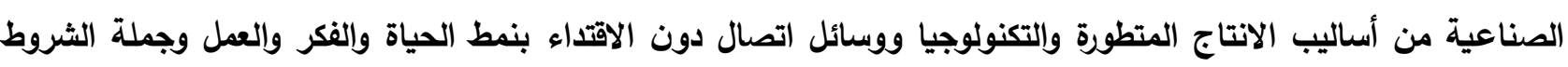

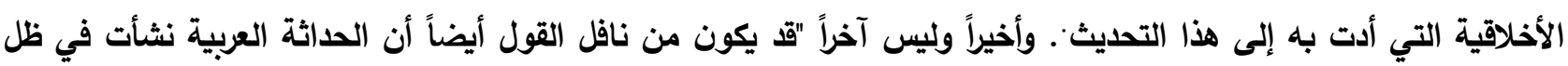

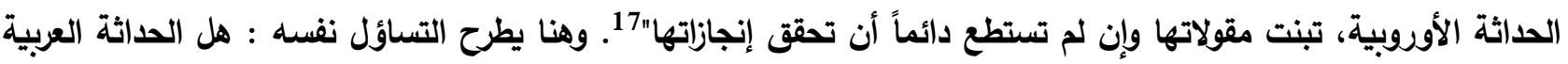

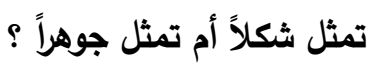

وللاجابة على هذا التساؤل يجب علينا طرح وجهة النظر على الجانب الآخر، فعلى إعتبار أن الذهن العربي ليس (كلاً) كما

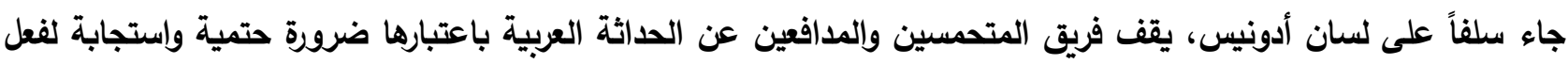

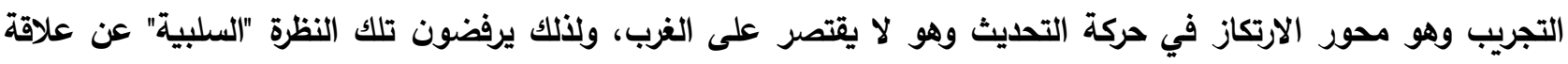

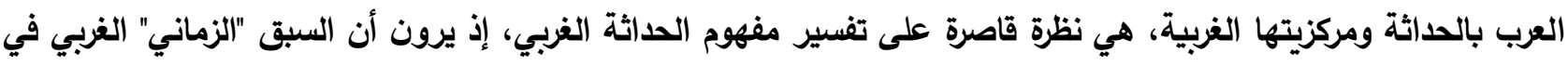

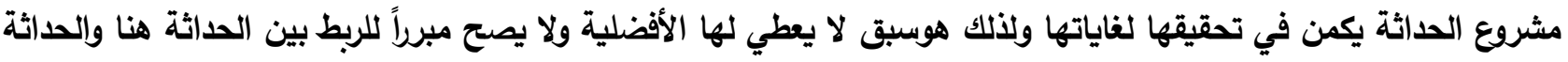

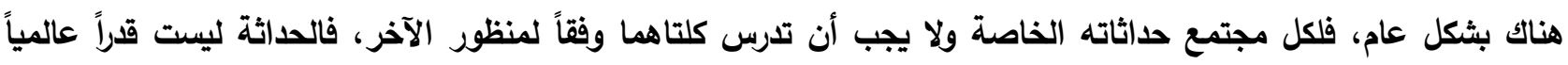

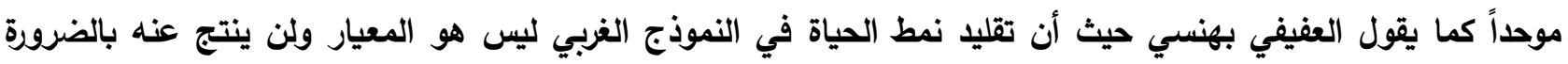

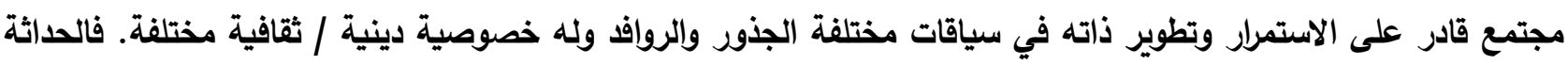

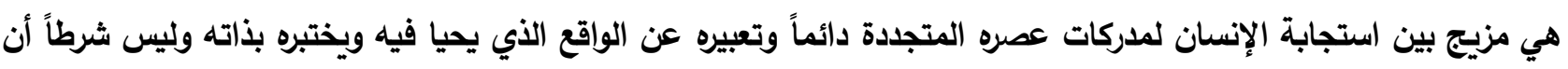

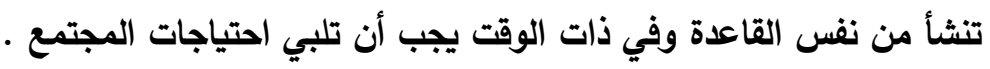

* يثير أدونيس في دراسته إلى حداثات عربية متعددة في مجال السياسة كما في تأسيس الاولة الأموية وفي الفكر ببدأ حركة التأويل وعلاقة الحياة

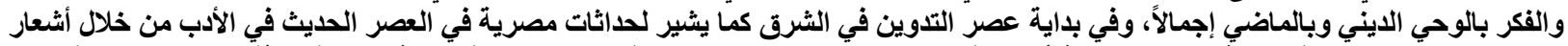

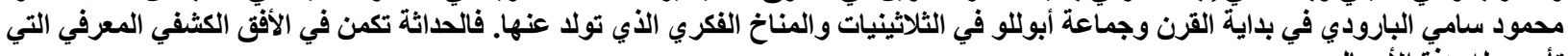
تأسس لله هذة الأعمال.

14 ـ أدونيس، الثابت والمتحول، بحث في الإبداع والأتباع عذد العرب، الجزء الرابع، 17ـ صدمة الحداثة وسلطة الموروث الثعري، دار الساقي، نسخة

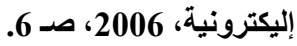

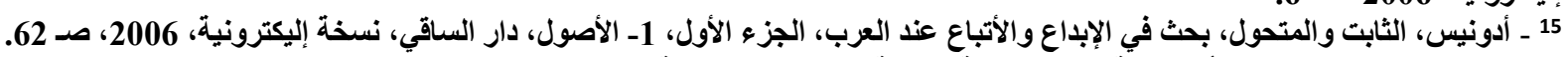

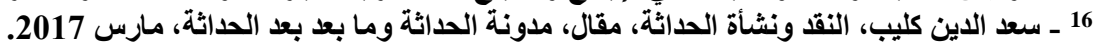
https://post2modernisme.blogspot.com.eg/2017 $03 \quad 01$ archive.html?view=classic 
إن الحداثة العربية هي محاوية بحث عن شرعية المستقبل كما يقول إلياس خوري*"18. وقد تم تبنيها كمفهوم وفلسفة ونمط

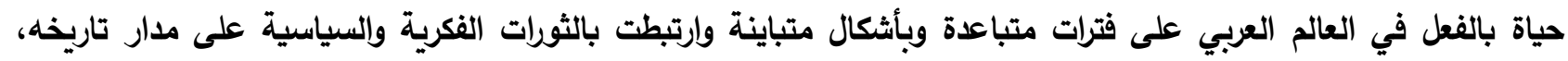

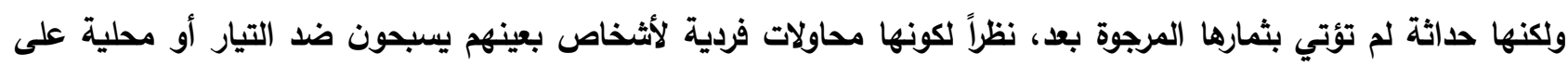

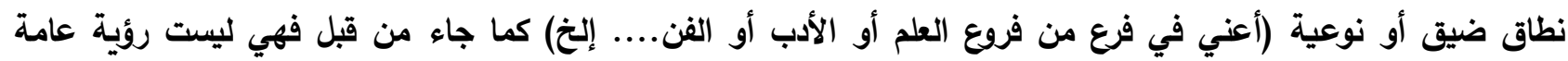

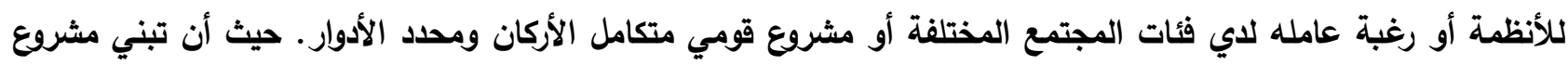
الحداثة يحتاج إلى كل ماسبق، فهي ثورة على النفس أولاً ثم على الثوابت والقوالب الجامدة وكسر للقيود ليصل بنا إلى القدرة على ممارسة فعل التغيير "وكل تغير كبير ينتج عن صراع. وكل تغير في مجال الفكر والفن لا يحدث بمعزل عن القوى الأخرى الفاعلة في المجتمع. 19 والحق إن الطابع الثوري والتغيرات السريعة المتلاحقة على كافة الأصعدة هما السمتان الواضحتان بجلاء في العصر الحديث،

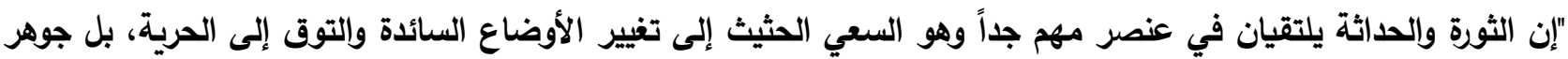

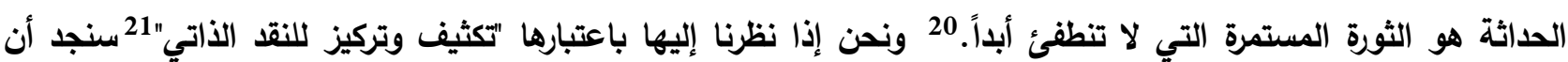
مجتمعاتنا العربية مازالت تواجة تحديات صعبة على طريق الحداثة.

فالحداثة العربية ملزمة باستخراج معياريتها وتملك المعرفة من ذاتها وليس من معايير غيرها أواصطياد الأمواج الثقافية من الآخرين كما يرى محمد سبيلا222 وهناك على سبيل المثال محطات خبرت فيها مجتمعاتنا العربية حداثات متعددة على فترات متفاوته كما في الحالة السوريه واللبنانيه في خمسينيات القرن التاسع عشر إبان النهضة الأدبية والعلمية كما حدث أيضاً في العرلق في نفس الفترة، وحديثاً وفي مجال الفن التثكيلي نذكر على وجة الخصوص ميلاد جماعات فنية أخذت على عاتقها

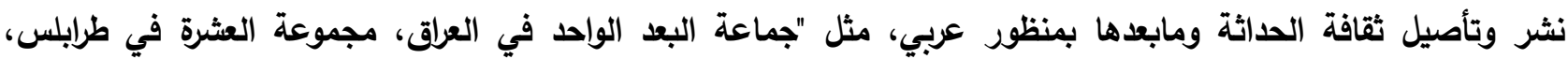

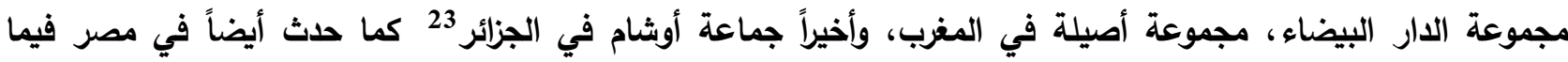
سيتناول البحث لاحقاً. وأخيراً وليس آخراً يمكننا النظر إلى كلا الموقفين بثيئ من الإيجابية ونقول إننا لا نستطيع أن نففل دور هذا التأثير والتأثر

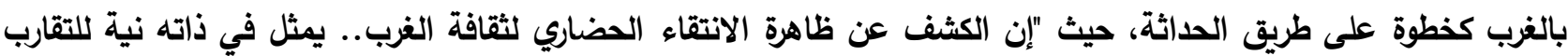
مع الآخر من أجل بعث جديد، بداية جديدة، تصبو نحو غاية لا نهائية "24 وتلك هي البداية.

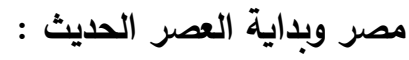
يعد المؤرخون تاريخ الحملة الفرنسية على مصر وبدأ فترة حكم محمد على، هو بداية التاريخ المصري الحديث ومما لا شك فيه أنه كان للحملة أثر كبير على خروج مصر من مرحلة ركود ثقافي طويل منذ منتصف القرن السادس عشر تقريباً والتي خبا

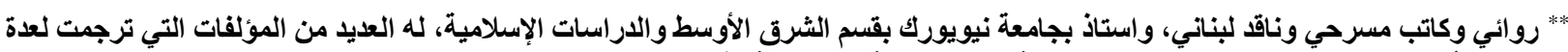

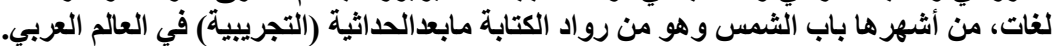

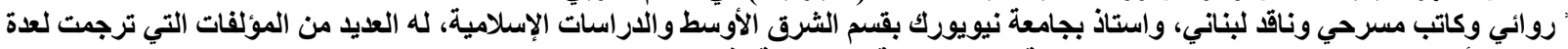

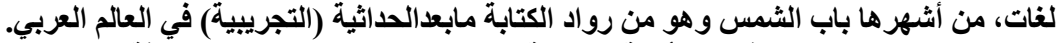

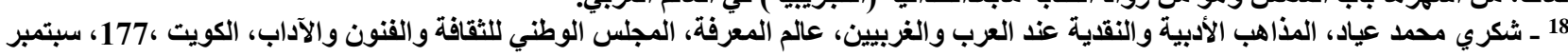

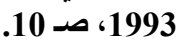
19 ـ شكري محمد عياد، المرجع نفسه، صد 149

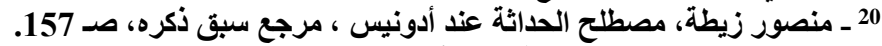

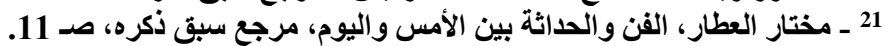

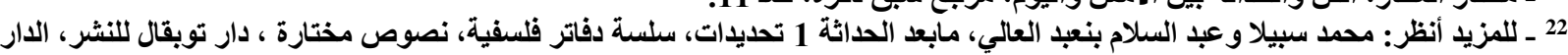

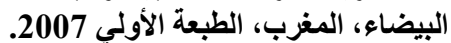
23 ـ للمزيد أنظر : هند الصوفي، الاتجاهات التصويرية في العالم الغربي والعربي منذ عصر النهضة وحتى الألف الثالث 1500- 2015، بحث مدعوم من

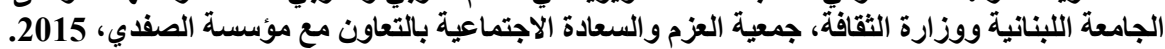

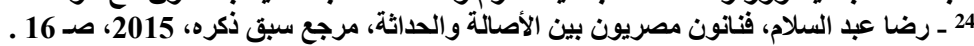


فيها نجمها من الساحة الثقافية بل من الممكن أن نقول انها غابت عن الفعل الحضاري برمته، فلقد حول الاحتلال مصر الى

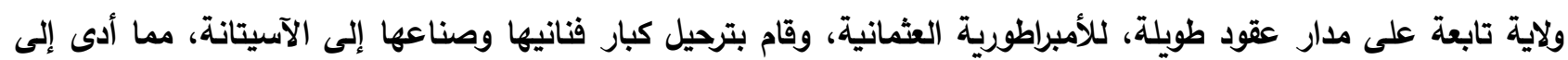
فقدانها الكثير من مقومات وجودها المادى والمعنوي، ومرت بفترات طويلة من التدهور الاقتصادي والثقافي كان لله أثر كبير

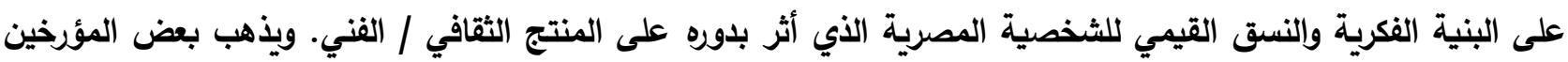

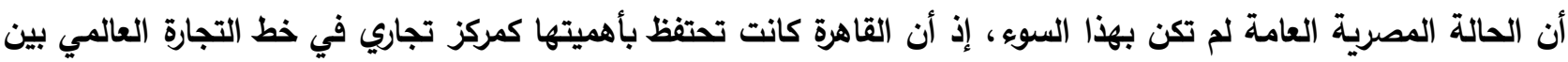
الثرق والغرب وأن هناك محاولات لبعث نهضة ثقافية وعلمية تبناها الأزهر الثريف كآخر ملاذ للمصريين جميعاً في تلك الفترة، وأن هناك إنتاج مميز للأدب الثعبي، والفنون التطبيقية التي أتخذ معظمها الطابع الإسلامي الزخرفي، ولكنها جهود غير منظمة ولا يجمعها أو يدعمها إطار شامل يؤسس لمجتمع حديث بالمعني الغربي.

أطلعت الحملة الفرنسية المصريين على النموذج الأوروبي والنمط الجديد من الحضارة والمدنية الغربية عن طريق الفنانين والعلماء المصاحبين لها في كافة التخصصات، اللذين جاءوا بعدد من المعدات والآلات (مثل آلة الطباعة الحديثة) وأتموا بناء العديد من المصانع والورش والمعامل ومجمعاً علمياً.. إلخ "وأصدروا صحيفتين فرنسيتين ونشرة باللغة العربية "25 كما كان لأهم ماتركوه من آثار (كتاب وصف مصر) أثر كبير على اتجاه الفنون على مدار القرن التاسع عشر بالاضافة إلى استقرار عدد كبير منهم في مصر بعد انقضاء الحملة ودخول محمد علي مصر واستقلاله بالحكم حيث كان لهم الفضل الكبير في تعريف المصريين على نموذج ثقافي أوروبي حديث، خاصة في مجال الفنون التي كانت أغلب مشاربها في هذا الوقت ينتمي للفنون الاسلامية. ثم جاء عهد حكم محمد على وأسرته من بعده، الذي أولى التعليم والثقافة والاقتصاد أهتماماً كبيراً، فأنثاً المدارس كالحربية والطب والهندسة والألسن وغيرها (التي كان لها دور فاعل ومؤثر في انبعاث النهضة المصرية ولية على يد رائدها رفاعة

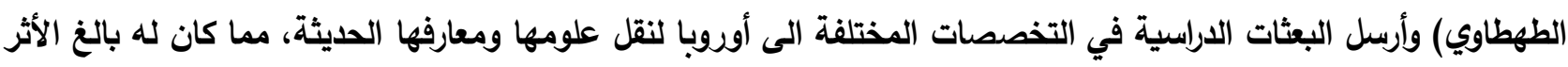

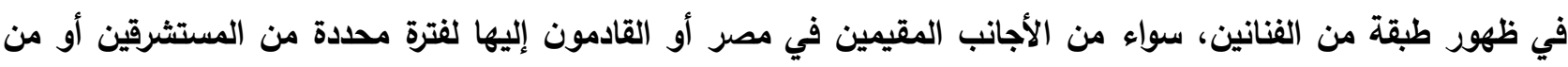

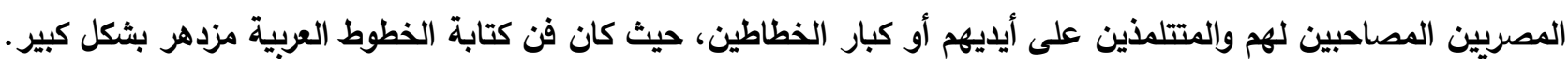
وبدأ التحديث كجزء متمم لمفهوم النهضة منذ أن بدأ العالم العربي في الخروج من ظلام العهد التركي كما يقول شكري عياد والبدء فيما عُرف فيما بعد بحركة البحث عن الذات وبناء مصر الحديثة على يد مجموعة المثقفين المصريين اللذين نهلوا من

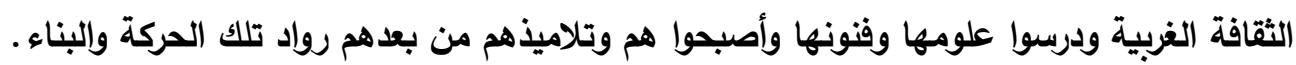

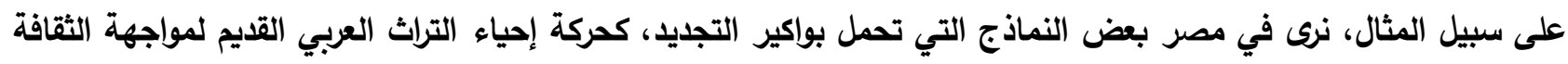

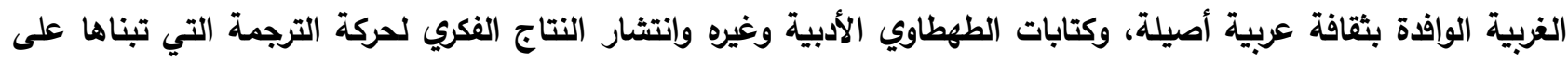

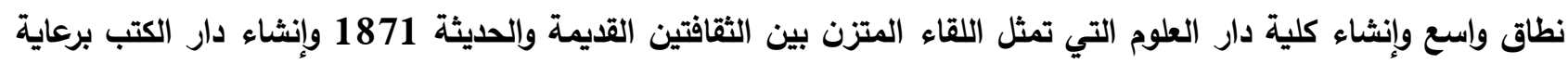
على مبارك، وإنثاء أول مسرح (عربي) 1870 تأسيس مطبعة بولاق 1821 وإصدار عداء مند من الصحف والمجلات والجمعيات للرواد المصريين أمثال محمد عبده والبارودي وعبد الله النديم وغيرهم من العرب والثوام اللذين استقروا في مصر مثل مثل جمال

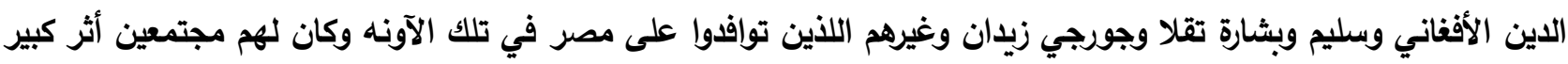

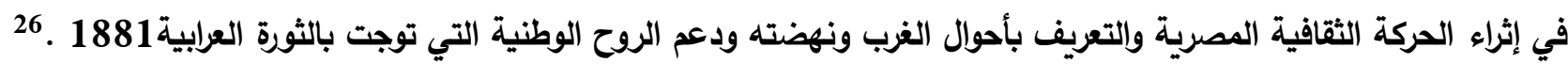

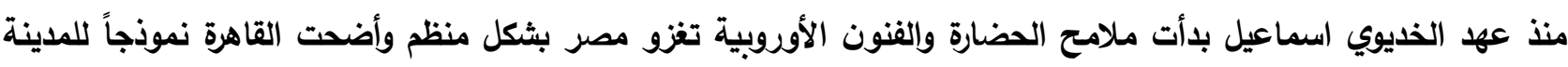
العصرية الحديثة على النمط الأوروبي بتخطيط شوارعها وميادينها وقصور الحكم فيها بما تحويه من تماثيل ولوحات وآثاث

25 ـ أحمد عبد المقصود هيكل، تطور الأدب الحديث في مصر، دار المعارف، الجزء الأول، الطبعة السادسة، 1994، صـ 25 ـ 26 ـ للمزيد،انظر: أحمد عبد المقصود هيكو هيكل، المرجع نقفسه. 
ومفروشات...إلخ إلا أن هذا الحال أقتصر على المدن الكبرى فقط وبشكل مظهري وبعيداً عن القاعدة الشعبية التي تمثل القوى الته

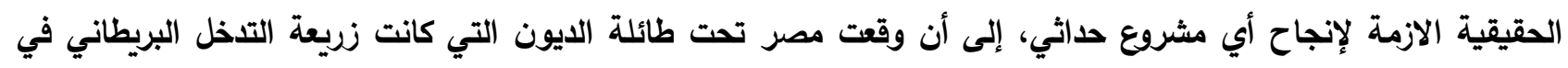

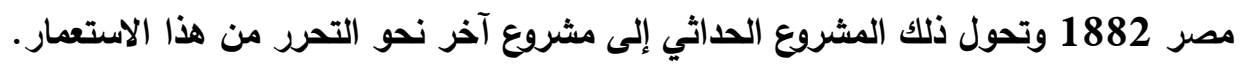

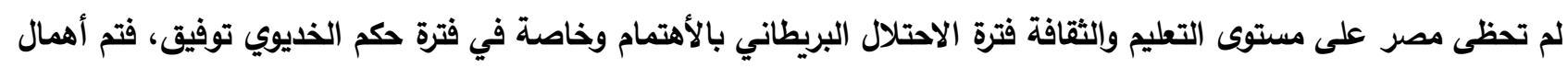

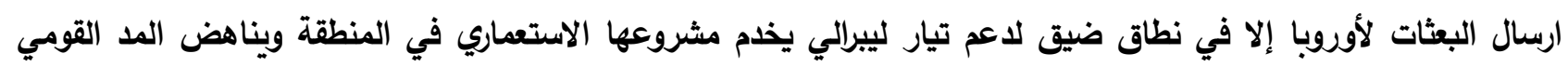

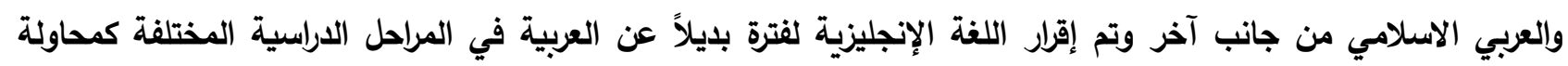

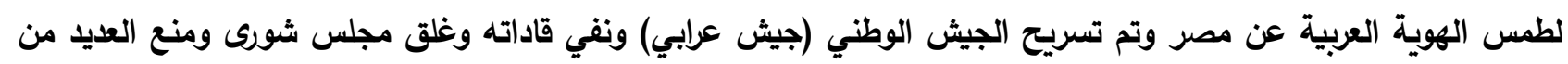

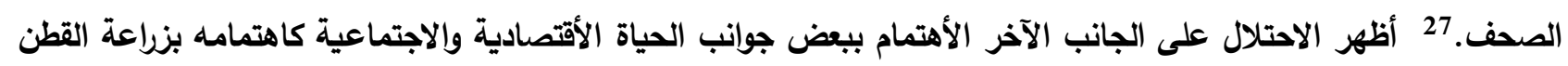

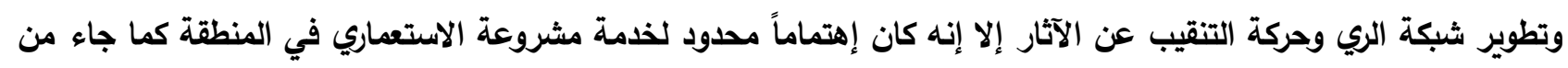

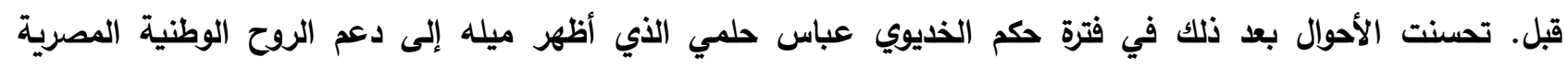

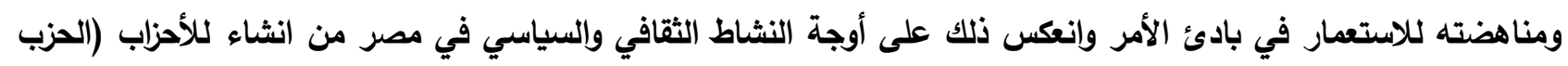

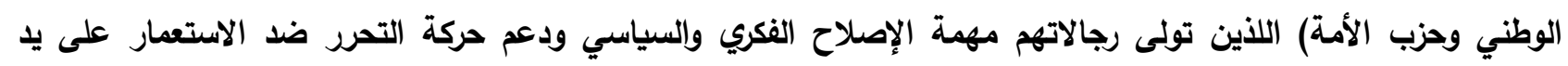
مصطفى كامل زعيم الأمة، إلى أن توج كفاحهم بقيام ثورة 1919. تزامن هذا الإصلاح مع بعض مض من الإلهم الأهتمام بالفن التثكيلي

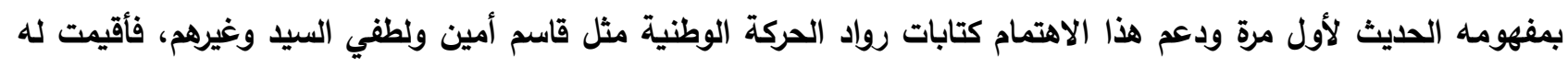

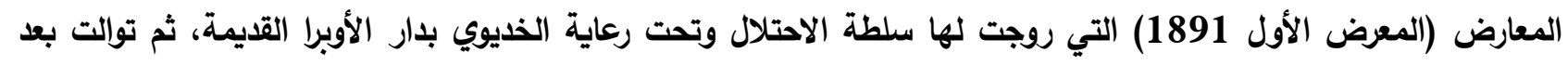

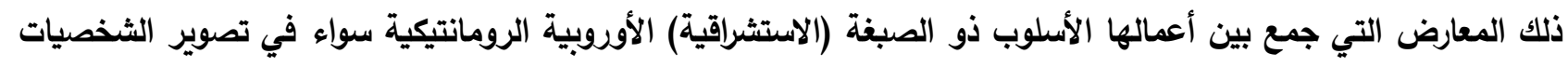

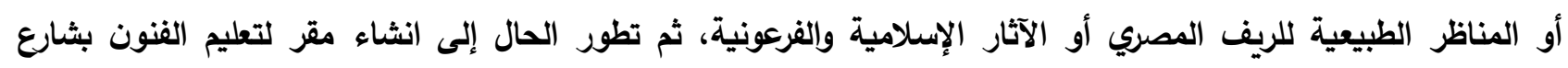
الخرنفش الذي أطلق عليه شارع الفن 28، إلى أن تم الأهتمام به بثكل مؤسسي كفرع الألمن من فروع الثقافة والمعرفة في السنوات

الاحقة.

جذور الفن المصري الحديث :

نشأت كلية الفنون الجميلة 1908 في ظل هذة الأجواء، تحت رعاية الأمير يوسف كمال وتزامنت نشأتها مع نشأة أول جامعة

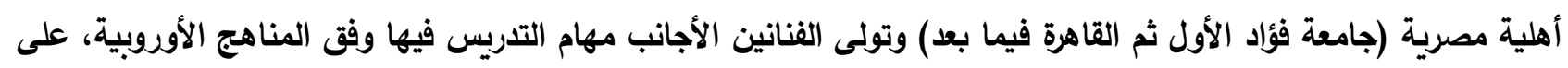

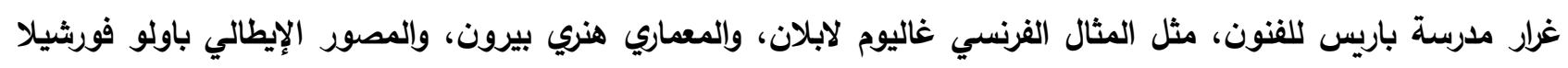
والمزخرف جيمس كولون وغيرهم، مما صبغ الفن المصري بالصبغة الغربية السائدة لعدة سنوات لاحقة. انشئ أيضاً نادي لائي للفنون الجميلة يضم مكتبة متخصصة في الفنون واتيحت عضويتة لجميع من يهتم بتقدم وإعلاء شأن الفنون الجميلة في

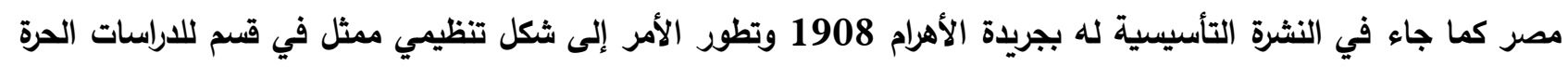
والتكميلية، له شروط للالتحاق ومدة محددة للدراسة وخصص لخريجيه منح ومكافآت عدة.29 وهكذا نثأ الفن التثكيلي

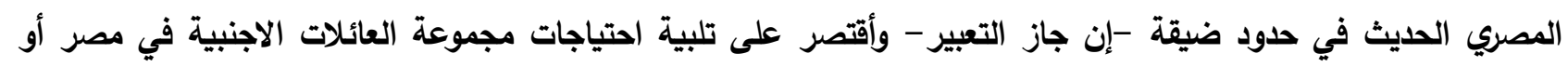
أبناء الطبقة الارستقراطية وعدد محدود من المواهب الثابه من المصريين وارتبط بطبيعة الحال بالنسق الفكري السائد بينهم،

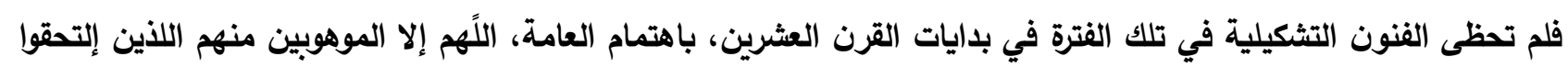

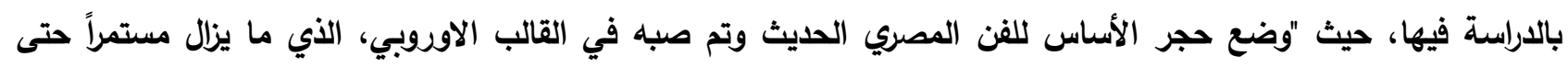


اليوم، وهذا هو السبب في الفجوة العميقة المزمنة بين الفن التثكيلي والمجتمع، لأنه نثأ منفصلاً عن ذوق المجتمع وحاجاته من الفن، باتخاذ موضوعات للاعمال الاكاديمية لم يفهم الجمهور مبرراً لها". 30 تخرجت أوائل الدفعات من قسمي العمارة والفنون وسافر عدو عدات منهم في بعثات إلى أوروبا وتثكلت على أيديهم الحركة التثكيلية

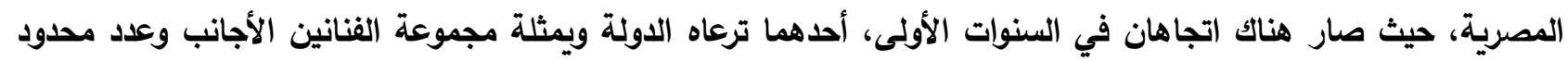
من المصريين اللذين كانوا ينظرون بثكل رومانسي جمالي إلى تراث الثرق بكل ما فيه والثاني يتبناه دعاة حركة التنوير من

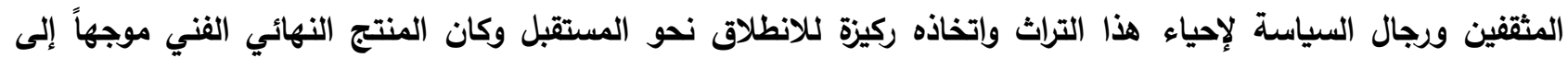
الجمهور الذي كان "معظمه أجانب ومن النخبة الثرية المثقفة من المصريين حتي ثورة 1919". 31 وهكذا انتقلت مظاهر

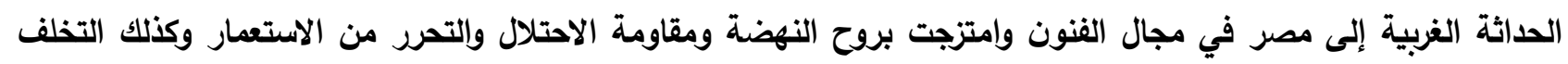
والجهل في الربع الأول من القرن العشرين، لتأسس لمرحلة جديدة تتجاوب مع معطيات العصر الحديث.

$$
\text { الحداثة في الفن التثكيلي المصري : }
$$

بوجة خاص وعلى مستوى الفنون التشكيلية كان النقاش أقل حدة حول ثقافة الحداثة ومابعدها، اللهم إلا في كتابات نقاد الفن بثكل متخصص في الربع الأخير من القرن العشرين، لطبيعة العلاقة بين الفن التشكيلي عموماً، وجمهور العامة الغير مبالي

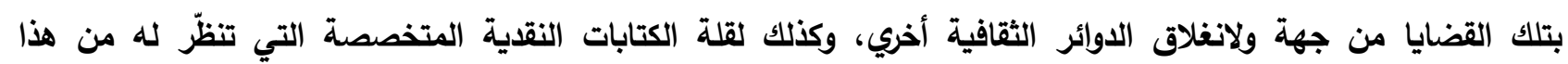

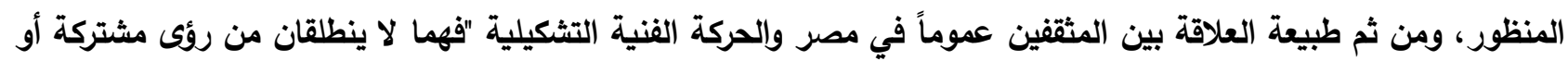
أسس فكرية وروحية جامعة أو نتيجة تطور مشترك واهتمامات تثمل الكتاب والفنانين .... وقات فثلنا حتى الآن في بلورة

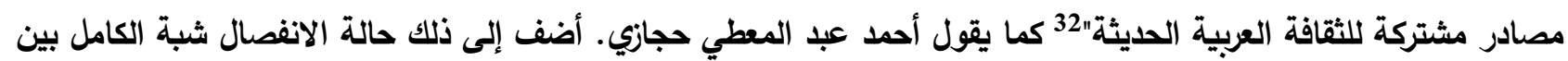
مجالات الفنون المختلفة في العصر الحديث، فالحركة الثقافية تحولت إلى جزر منعزلة. ولذلك تناول البحث باستفاضة تعريفات التهات

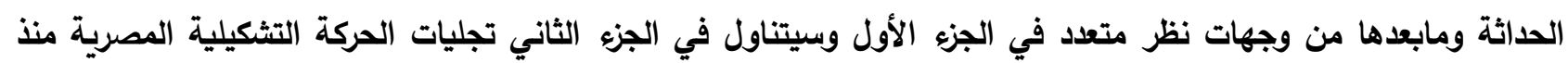

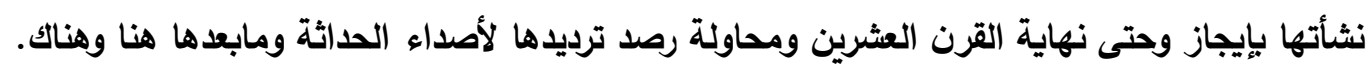

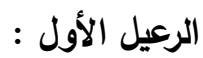

إذا نظرنا إلى الفن من حيث هو ذاكرة الأمم وفي ذات الوقت هو إعادة تثكيل للواقع في ظل معطيات جديدة، سنجد أن أعمال الرعيل الأول تمثل تلك المقولة خير تمثيل. وهي تمثل عصر النهضة التي تبلورت خلالها الثخصية الفنية المميزة للفن المصري الحديث والتي تم تبنيها وتجسدها في أعمال الرعيل الأول "محمود مختار 1891 ومحمد حسن 1892 وئ 1982 ويوسف كامل 1891 وراغب عياد 1982 وأحمد صبري 1889" وغيرهم من أوائل خريجي مدرسة الفنون الجميلة أو محمد ناجي 1988 أوني الذي درس القانون ثم فن الرسم على يد فنان إيطالي بالأسكندرية وكذلك جورج صباغ" 1887 ذو دون الأصول الأجنبية، فجميعهم اشتركوا في أكمال دراستهم في أوروبا ثم العودة إلى مصر وتولي قيادة حركة الفن التشكيلي الحديث.

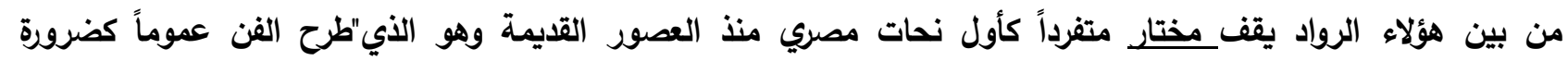
قومية"33 حيث كانت "لايه القدرة على فهم الحاجة إلى فن مصري، والالتجاء من أجل ذلك إلى تعاليم مصر القديمة"34 فنراه

http://www.dar.akhbarelyom.com/issuse/detailze.asp?mag=a\&field=news\&id=10877

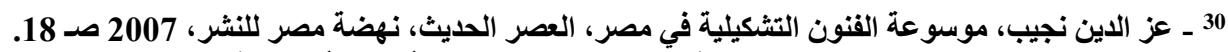

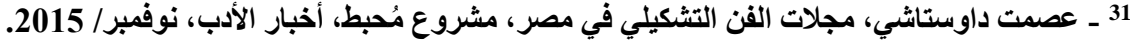

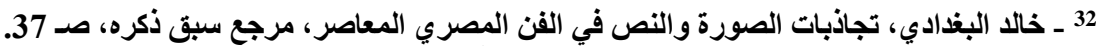

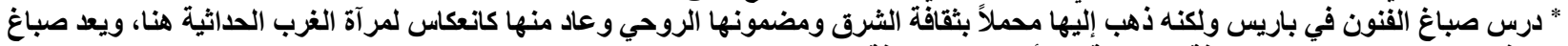

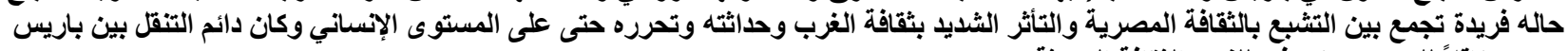

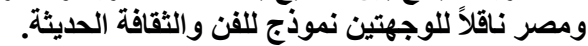
33 ـ سيد هويدي، المبثرون فنانون يحلمون بواقع جديد، المجلس الأعلى للثقافة، القاهرة، 2012، صـ 100. 
يتغنى بجمالياتة القديمة الخالدة ويوظف خامته الصلدة (الجرانيب) في أعماله النحتية الصرحية في اقتداء بالمصري القديم

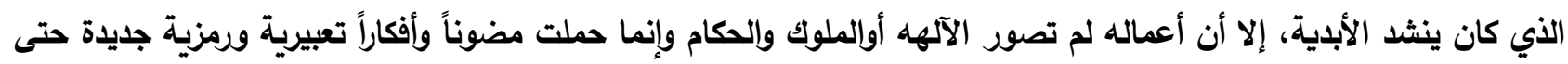
في تناول الثخصيات التاريخية وإن استخدمت القالب التشكيلي الكلاسيكي. فأعمال مختار قد اتخذت من الإرث القديم ركيزة للانطلاق وهي أعمال نابعة من بيئتها المحلية ومحيطها الاجتماعي، دون محاكاة. وكما قال عباس العقاد في مقاله (تمثال

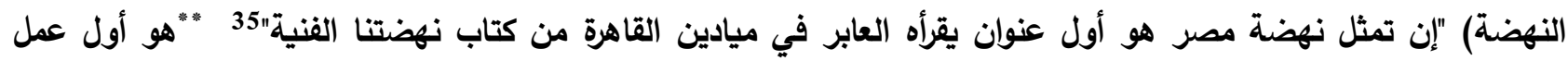

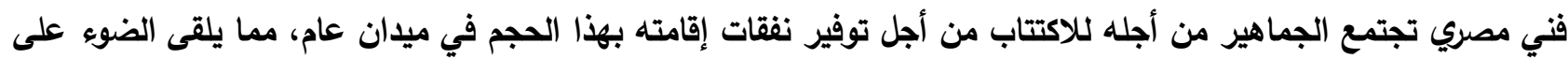

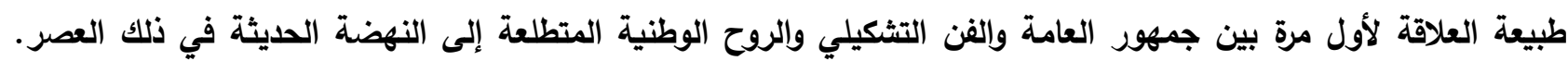

أينما يمتلئ المخزون البصري بتفاصيل الحياة الثعبية وأنماطها المختلفة وحاضرها الريفي، والمدني ويمتزج بجماليات الإرث الفني للحضارة المصرية القديمة، تقف أعمال راغب عياد معبرة بأصالة عن هذا التفاعل، فنجد في أعمالة الرغبة في التأكيد على الهوية والانتماء لتلك الأرض الطيبة باستخدام قوالب فنية وتبني قيم جمالية تمثل اللإرث الفني المصري القديم وإختيار موضوعات مثل مراحل العمل في الحقل والحياة في الريف والأسواق الثعبية وإخراجها في قالب فني فُ فئعم بالحيوية والنشاط والحس التعبيري القوي عن طريق توظيف الخطوط الموجهه للعناصر بحجومها المختلفة في اكتناز واحياناً في استطالة وضربات الفرشاة التي توحي بالأسطح الخشنة والخلفيات التي لاتخلوا من المشاهد البانورامية للبيئة المصرية في تصميمات أغلبها أفقية تذكرنا بكراسات النماذج وشرائط الكتابة المصرية القديمة ورسومها التحضيرية وهو بذلك قدأل أضفى على الذائقة

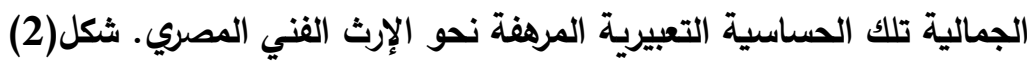
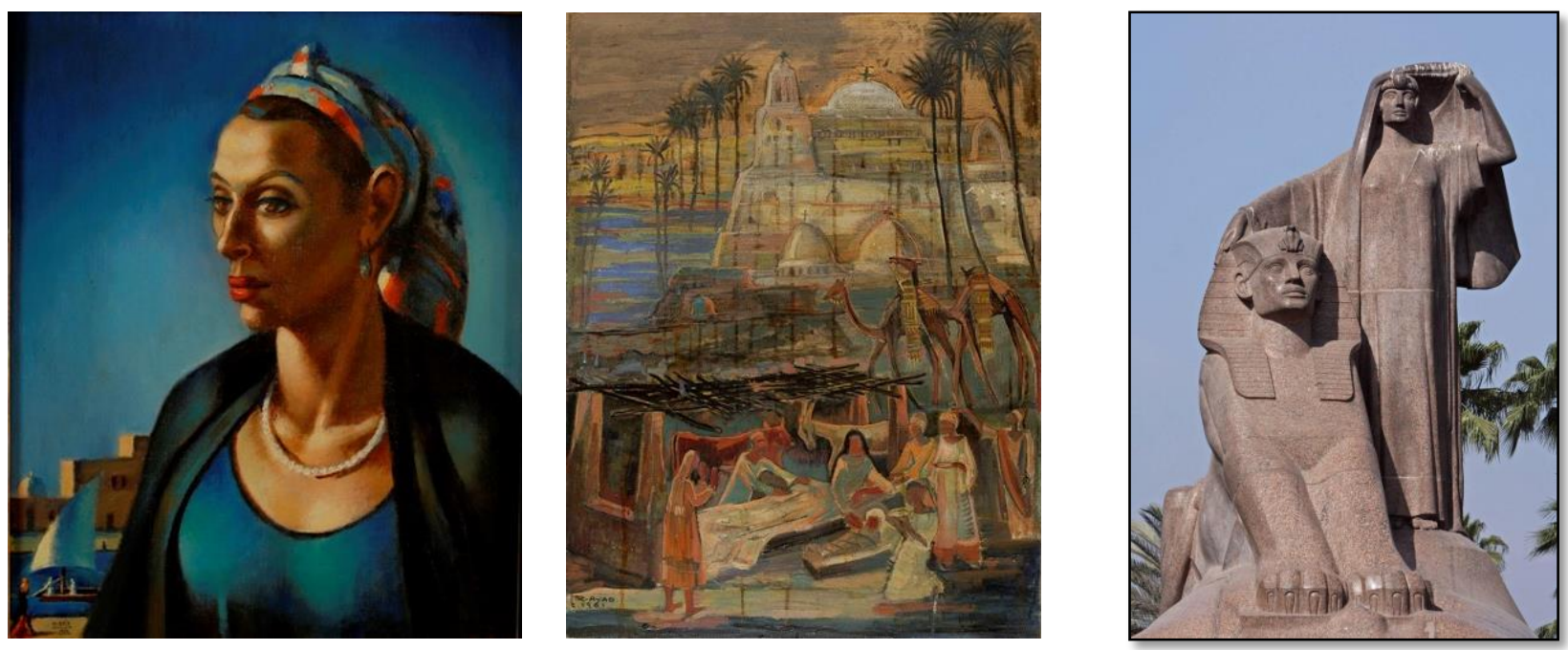

شكل 3- محمود سعيد، سيدة ترتدي عقد من الؤلئ، زيت على سوليتكس، سئل

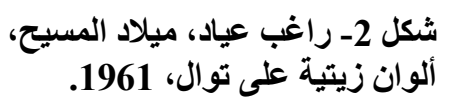

شكل 1- محمود مختار، نهضة

مصر، جرانيت وردي، 1928.

34 ـ إيميه آزار، التصوير الحديث في مصر حتى عام 1961، 1961، ترجمة إدوارد الخراطو نعيم عطية، المجلس الأعلى للثقافة، المشروع القومي للترجمة،

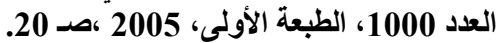

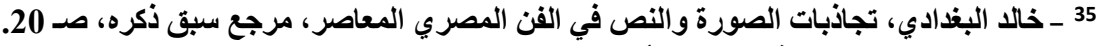

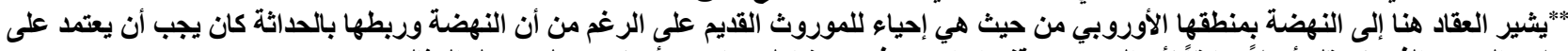

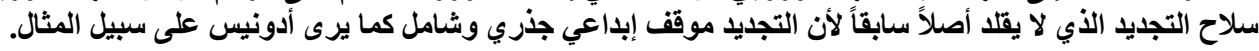




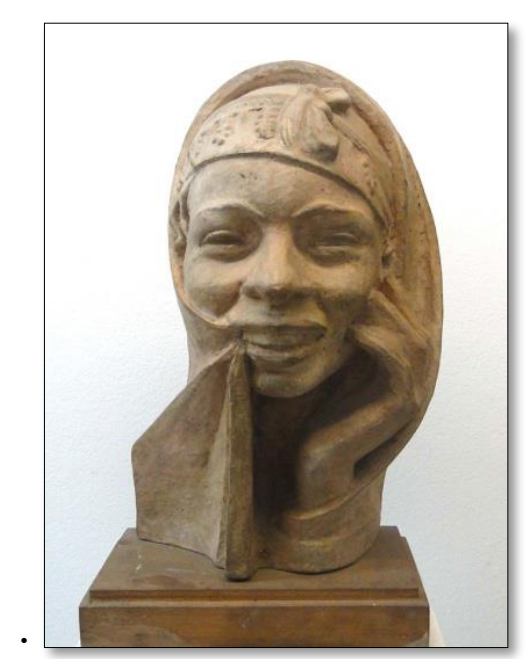

شكل 7- أحمد عثمان، فلاحة، طين صلصال، د.ت.

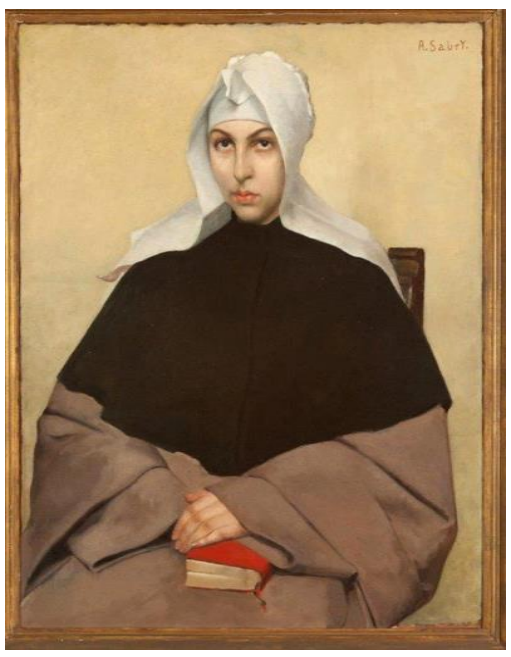

شكل 5- أحمد صبري، الراهبة، زيت على توال، 1929.

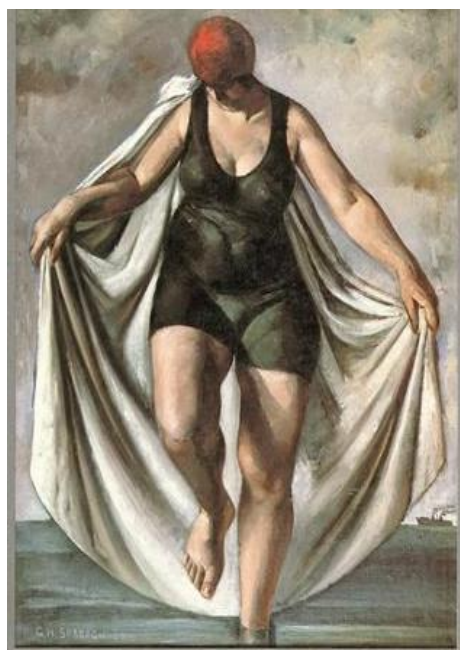

شكل 4- جورج صباغ، ميلاد فينوس، زيت على توال، 1922.

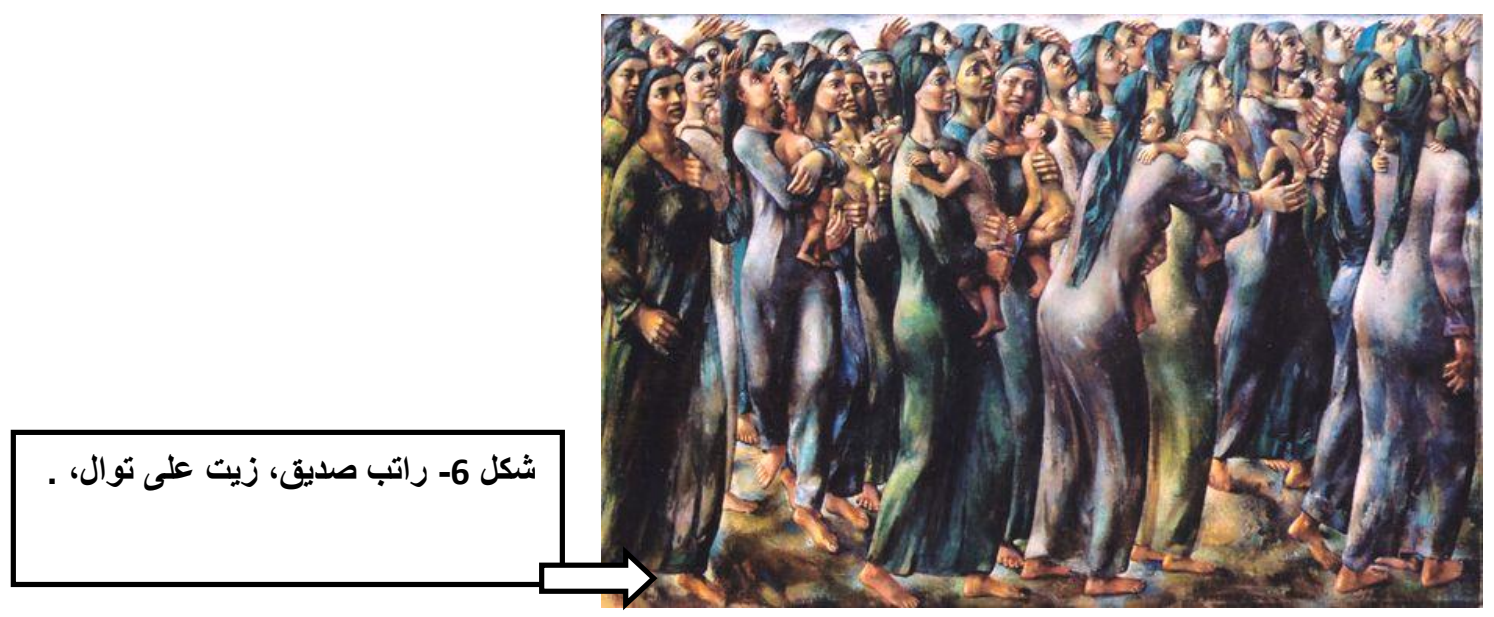

أما محمود سعيد فهو رائد التصوير المصري الحديث بحق، فقد تميزت أعمالة بتناول موضوعات ومشاهد البيئة المحلية، وخاصة السكندرية منها، وتضمينها بمعاني شديدة الحسية في تناول أسطوري حالم وتوظيف عناصر ضخمة راستخة رئنة تتموضع في بساطة وشاعرية داخل تكوينات بنائية هندسية. تميزت أعماله بالتنوع بين عنصري الثبات والحركة واستخدام الألوان المشرقة الساطعة (كالأصفر الذهبي والنحاسي والأحمر) التي تتوهج في تدرج ونعومة في تضاد مع الأطر الخارجية الداكنة والتوظيف المتنوع للخلفيات البانورامية في اللوحات التي تعالج مشاهد من الطبيعة أو طقوس الاحتفالات الشعبية أو تصور الثخصيات العادية بقسماتها الثديدة المحلية ذات الحضور الطاغي (خاصة النساء) والتي تؤكد على تأثره بالفنون المصرية القديمة ومدى اطلاعه على اتجاهات التصوير العالمية كأعمال فنون الباروك والواقعية والانطباعية والتكعيبية التي خبرها أثناء

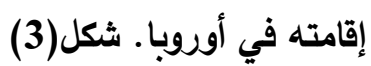

ومما سبق، يمكن أن نقول إجمالاً ان أعمال الرعيل الأول تدخل جميعها ضمن تيار تأكيد الهوية والانتماء وشحذ روح النهضة

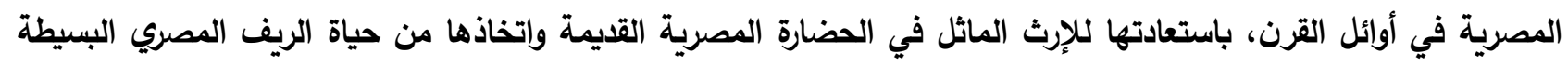

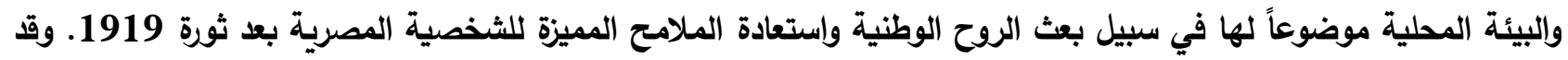

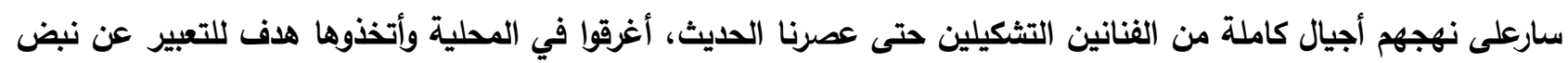

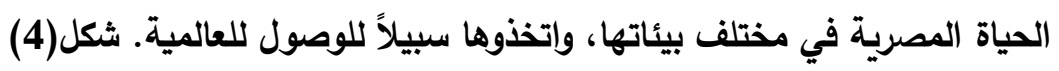


أما عن مكانة هذة الأعمال وموقعها من تيار الحداثة: فيظهر بالفعل في أعمال هذا الجيل مدى التأثر بالاتجاهات الفنية الأوروبية واجتماعهم على توظيف صيغ فنية متقاربة مع بعض الأختلاف في الميل إلى الكلاسيكية أوالرومانسية أوالواقعية

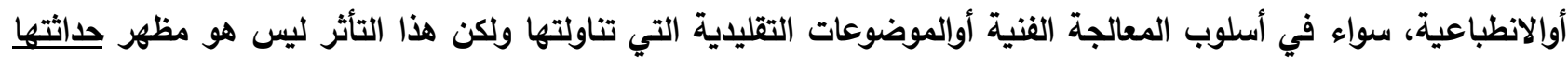

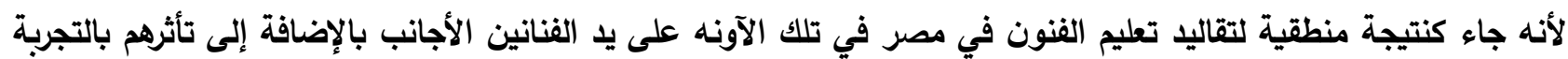
الغربية الجمالية أثناء ابتعاث أغلبهم إلى هناك، وإنما واقع حداثثها الحقيقي هو: أستطاعتها التأسيس لحركة فنية تثكيلية

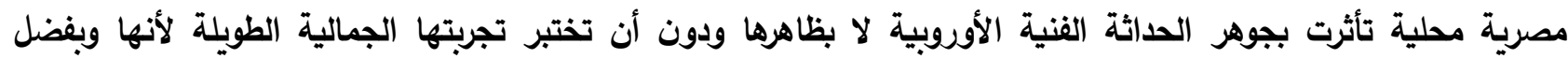

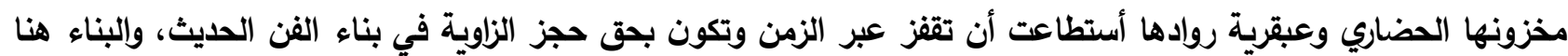
هو جل حداثتها.

وما يأخذ على أعمال الرواد من أنها لم تأتي بجديد (حداثي) لنسجها على منوال الأقدمين هو حكم متحيز للحداثة الغربية، فكما

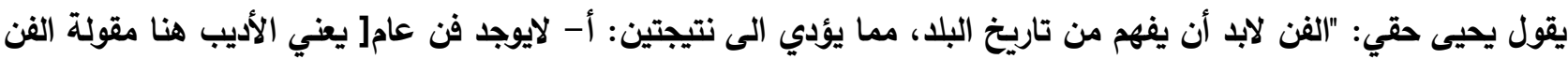

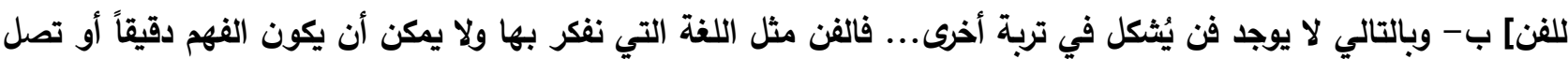
المتعة المتحققة من فعل القراءة الى ذروتها الا من خلال لغتنا."36

تبقى هنا الإثارة إلى أنه وحتى الربع الأول من العشرينيات لم يكن هناتك كيان واحد منظم (مدرسة أو جماعة أو مؤسسة) لها اتجاهات محددة في عالم الفن ولذلك تم الإثارة إلى الحقبة الأولى كرعيل أول للحركة الفنية، بتعدد تجاربهم وتنوعها، ثم سيتناول البحث الفترات الاحقة بترتيبها الزمني وفق تواريخ نثأة الجماعات المميزة لها أو الأحداث الهامة على الصعيد السياسي والاجتماعي، مع الأخذ في الاعتبار أن الثكل التنظيمي لكل جماعة وكذلك انتاج أعضائها الفني قد استمر لفترات طويلة كتيار أو أسلوب عام في السنوات الاحقة واقترن أحياناً بحياة روادها أو انتقالهم من جماعة إلى أخرى وكذلك اختلاف توجههم الفني على مدار حياتهم. وهنا يجدر الإثارة إلى أن صعوبة الحصول على معلومات دقيقة عن الأعمال الفنية لجيل الرواد وخاصة أبعادها ومكان وجودها، في أغلب المراجع العربية والمواقع الاليكترونية وهو مايؤخذ على نقاد الفن ومؤرخيه

كان فنانو الرعيل الأول قق حققوا مكانة إجتماعية مكنته من التأثير المباشر على الساحة الثقافية واكتسبوا من الثهرة ما مكنهم من خلق مكانة إجتماعية للفنان التشكيلي داخل المجتمع المصري ونثر للثقافة التثكيلية عموماً وثقافة إمتلاك العمل الفني المصري خاصة فن الصورة الثخصية، شكل (5) (أعمال أحمد صبري على سبيل المثال لا الحصر) بعيداً عن النسخ المتكررة للوحات الزيتية من مشاهد الطبيعية الأوروبية والنسجيات المرسمة. "ومع تعاظم الطبقة الوسطي من المصريين (الأفندية) وتأسيس جمعيات مصرية معنية بالفنون والثقافة مثل جمعية محبي الفنون الجميلة عام 1922 وأتيليه الأسكندرية 1935 تزايد متذوقو الفنون الجميلة من عامة المصريين"37 وكانت تلك الجمعيات تضم في عضويته الاجانب إلى أن تقلص عددهم وفي ذات الوقت ظهرت على الساحة جماعات فنية أخرى تتبني مفاهيم وأفكار حداثية على غرار

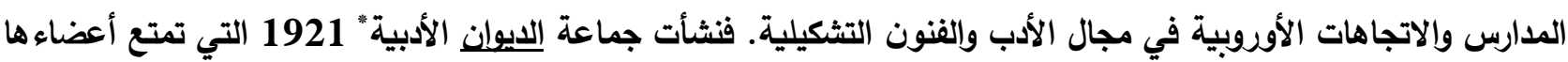
بنفس الصفات من انتمائهم للجذور المصرية مع التأثر بالثقافة الغربية وخاصة الأدب الانجليزي والرغبة في الثورة على

36 ـ يحيى حقي، في محراب الفن (موسيقي - تثثكيل - عمارة) نهضة مصر للطباعة والنثر و التوزيع، 2008، صـ 8.

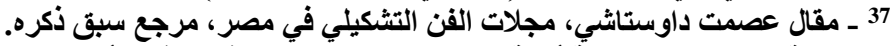

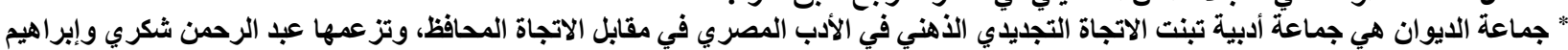

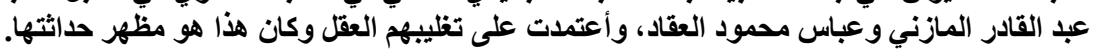


الاتجاهات المحافظة وإلتطع لمستقبل أفضل. وتزامن مع نشأتها نثأة جماعة الخيال وهي أول وأهم الجماعات الفنية في مصر، والتى اسسها مختار 1928 بعد عودته من أوروبا بهدف تأسيس دعائم فن مصري قومي، وضمت ضمن ضمن أعضائها

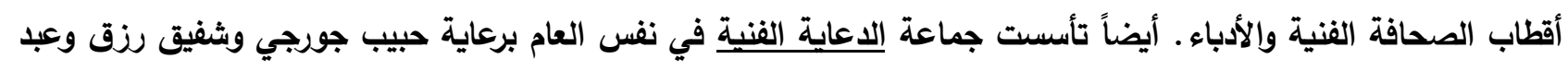

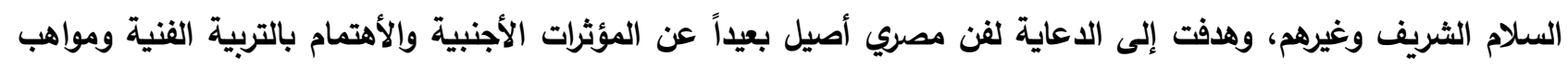

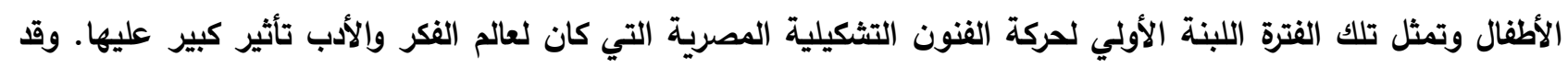

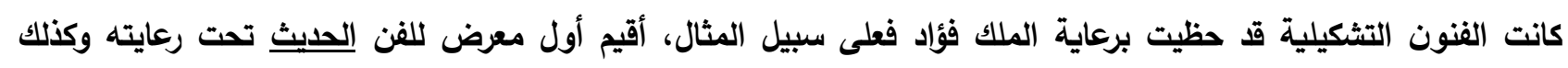

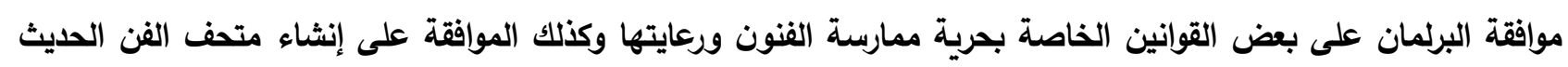

1927 وافتتتاحه بعدها بأربع أعوام . 38

بأت الثلاثينيات وتعددت التجارب على نفس الدرب فأسس محمد صدقي الجباخنجي المجمع المصري للفنون الجميلة 1933

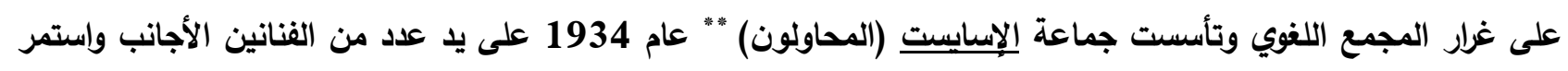

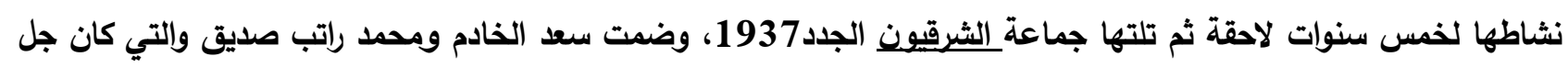
أهتمامها "ضرورة تأصيل التجربة الجمالية كي تكون مصرية في ملامحها ومضمونها، عن طريق استلهام التراث والتعبير عن

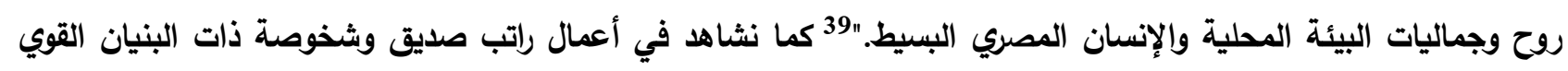

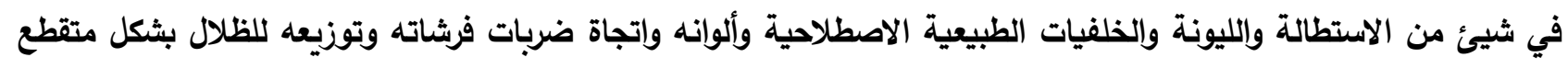
طولي كألسنة اللهب بطريقة دينامية تذكرنا بأعمال ألجريكو فنان عصر النهضة (المانيرزم) وبأعمال التعبيرين الألمان ولكنها

تحمل مضمون مصري صميم، شكل (6). وتميزت الأعمال الفنية في تلك الفترة أيضاً بسيرها على خطى الرعيل الأول اللذي شكل بالنسبه لهم أسلوباً أكاديمياً يحتنى به

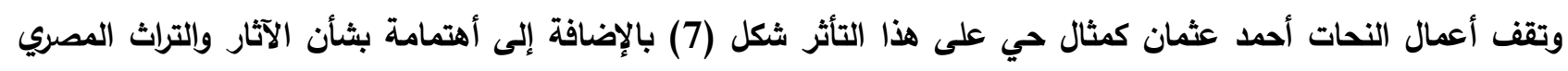
وهو الذي قدم التصميم والحل الأمثل لأهم مشروع حضاري- فني- أثري برعاية اليونسكو في الخمسينيات لنقل معبدي أبوسمبل

من موقعهم القديم إلى موقعهم الحالي. الجدير بالذكر هنا هو أنضمام كامل التلمساني لجماعة الثرقيين الجدد كما يقول إيمي آزار ولكنه نحى منحى مختلف فنراه

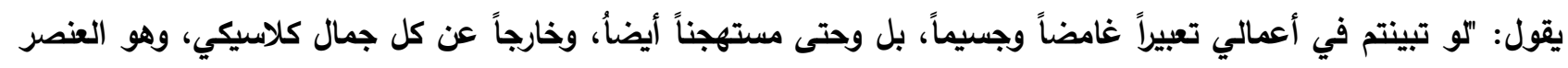

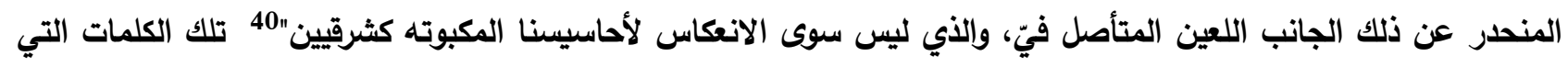

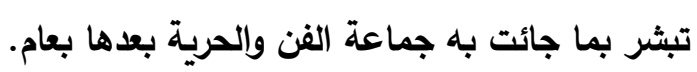
أستمر الحال على هذا النحو إلى أن ألقت الأزمات الاولية مثل الكساد الكبير وقيام الحرب العادهات العالمية الثانية بظلالها على مصر،

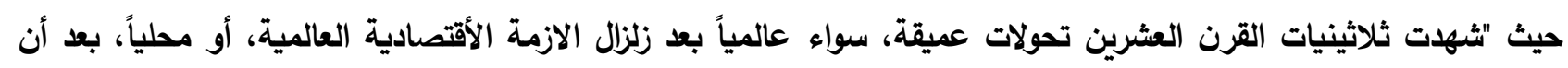

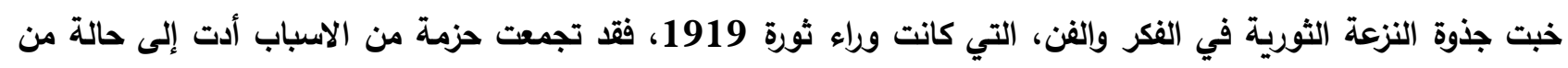

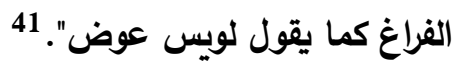

38. Wijdan Ali, Contemporary Art from the Islamic World, Scorpion Publishing Ltd, London, on behalf of The Royal of Fine Arts, Amman, 1989, P36.

** الإسايست، جماعة فنية استمر نشاطها حوالي خمس أعوام،اسسها:جول ليفي والبرت ساليتل وارتبط اسمها بمجلة "أن أيفور" (إجتهاد) التي تصدر http://rawi-magazine.com/ar/articles/articulating_art/

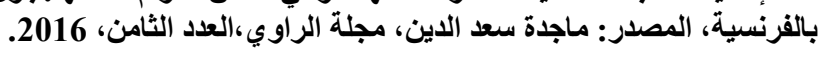

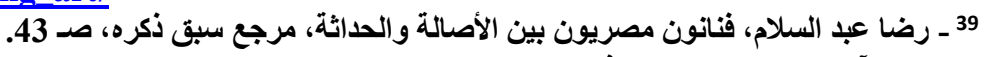

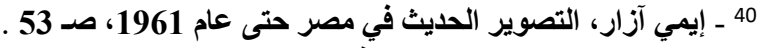
http://elsada.net/5838

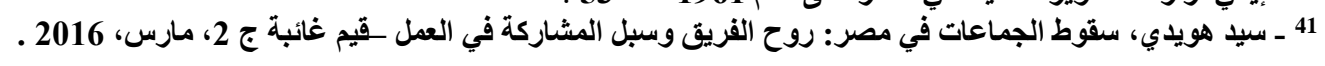



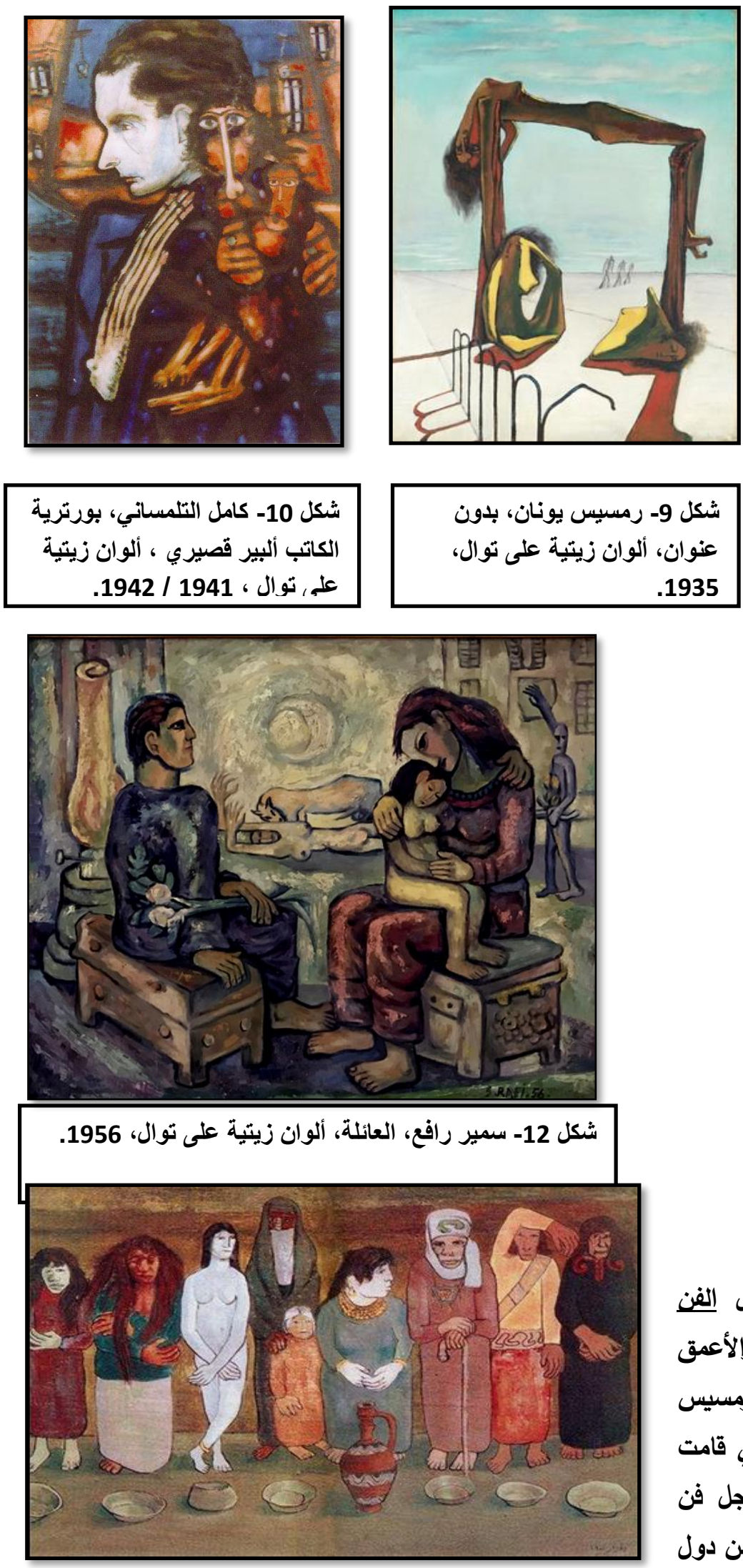

شكل 13- عبد الهادي الجزار، الكورس الشعب، ألوان زيتية على

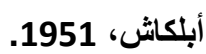

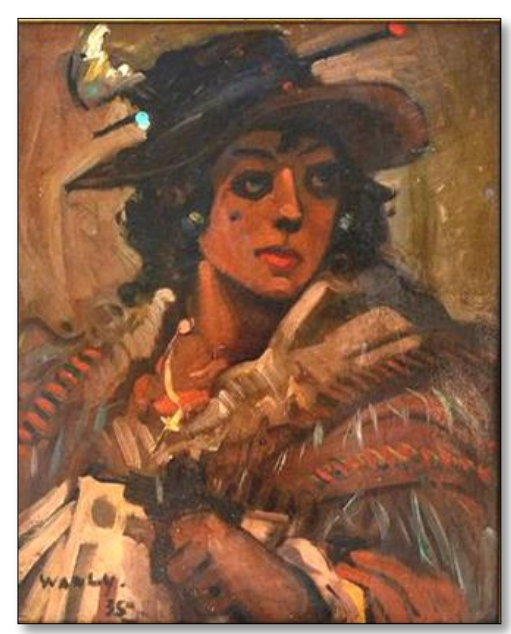

شكل 8- أدهم وانلي، ميريكا، ألوان زيتية على خشب، 1935.

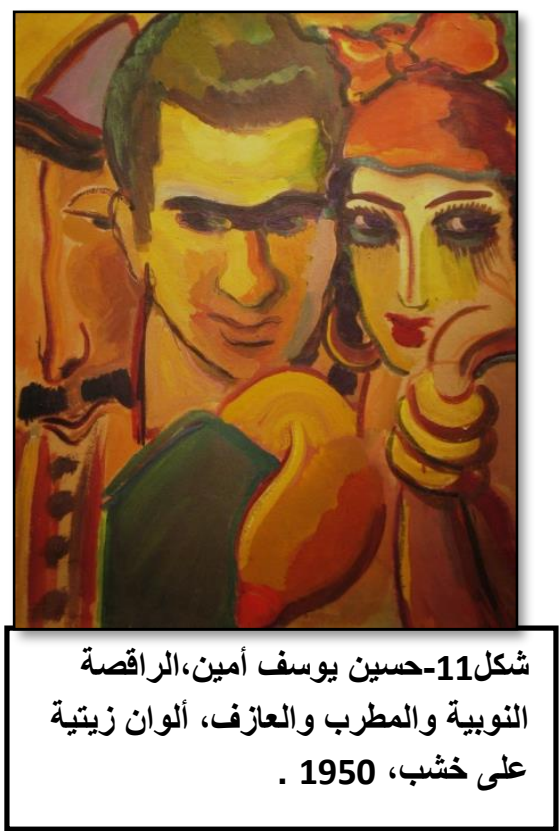

شهدت تلك الفترة أيضاً تأسيس جماعات مثل الفن

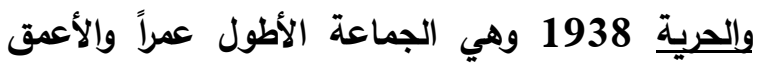

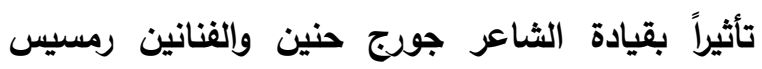

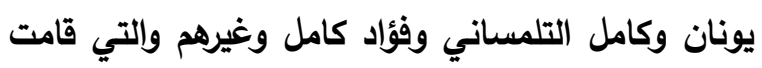

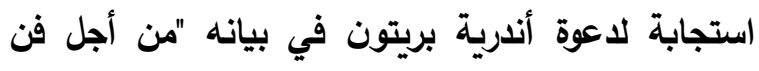

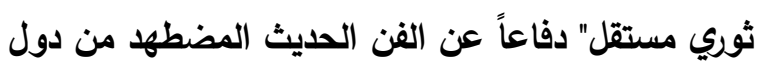
المحور (ألمانيا وحلفائها) وجاء في بيان الجماعة الذي دون النيات وقع عليه 37 فناناً "أيها المثقفون والكتاب والفنانون! ولياء فلنعلن معاً العصيان، فهذا الفن المنحل يخصنا جميعاً 
كمثقفين، فيه تكمن كل فرص المستقبل، فلنعمل من أجل نصرته على العصر الوسيط الذي ينهض في قلب الغرب من جديد"42. أن من أهم انجازات تلك الجماعة هو وجود الكتابات النقدية والتنظيرية لأعمال فنانيها ومبادئهم باللغة العربية والفرنسية أيضاً

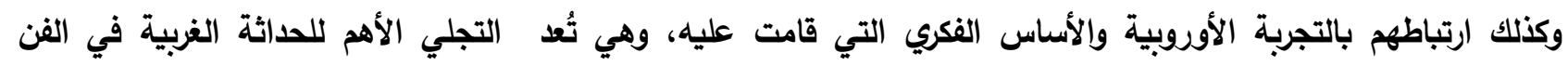
المصري، فقد أصدرت الجماعة مجلة التطور 1940 (مع ملاحظة أن الأسم في ذاته يحمل مضموناً حداثياً) لتقديم رؤيتهم

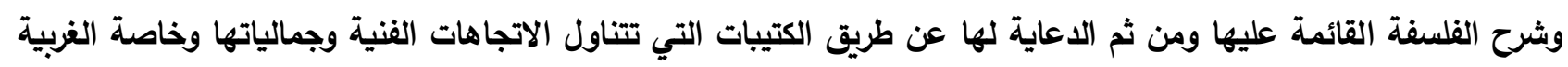

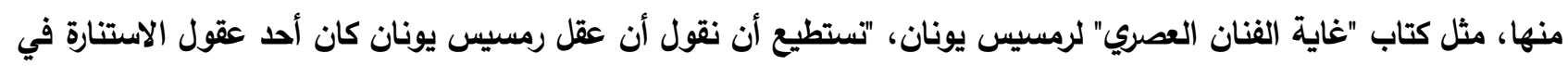
الحركة التثكيلية المصرية... حتى الآن لن نجد عقلاً يماثلة"

وهنا يجب الأخذ في الأعتبار انتقال بعض الفنانين بين الأساليب الغربية والاسلوب المصري الحديث (الكلاسيكي إن جاز

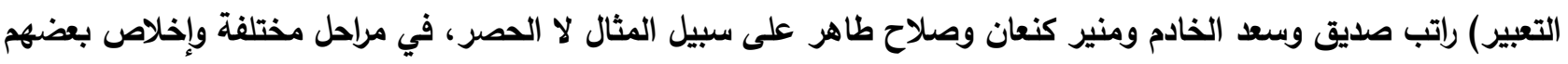

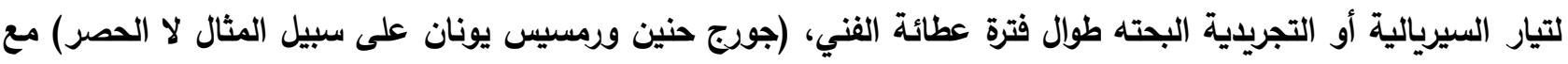

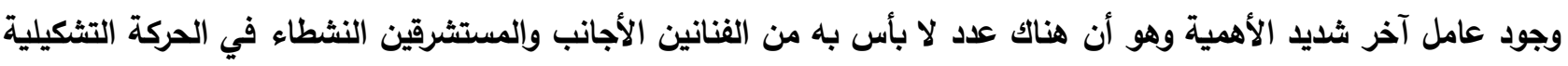
منذ نثأتها مثل بيبي مارتان وإيمي نمر ومارجو فييون وصاروخان وأرستيد بابا جورج وغيرهم أو فناني أتيلية الأسكندية

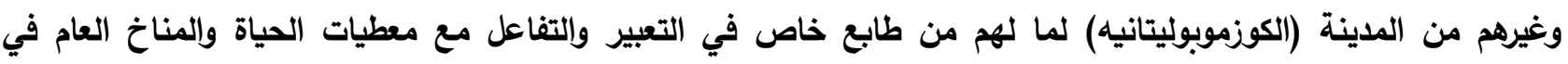

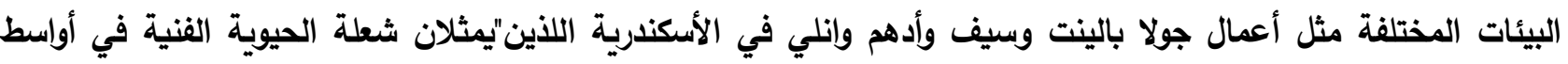

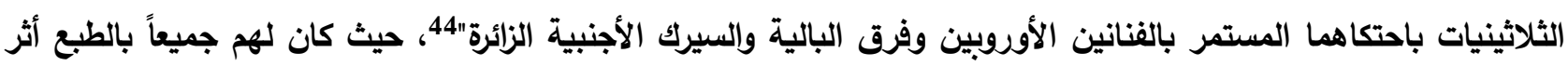

كبير على حركة الفن التثكيلي على مدار العقود اللاحقه. شكل (8).

من زاوية أخرى ظلت هذة المفاهيم الحداثية والثورية الغربية التي دعت إليها تلك الجماعة، خاصة في مجال الفنون حبيسة دوائرها من المثقفين نظراً لفوقيتها وتعاليها بعض الثيئ عن الجماهير وكان لبثثها عن الحرية (إطلاق العنان للخيال السجين دون التقيد بأي أفكار أو نماذج مسبقه) بالاضافة إلى تأثرها الثكلي الواضح (السلبى من وجهة نظر الباحثة) بالأعمال الفنية

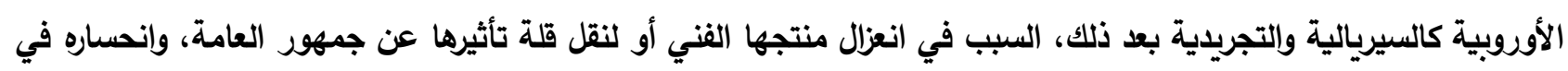

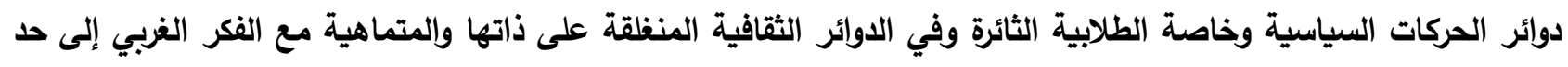

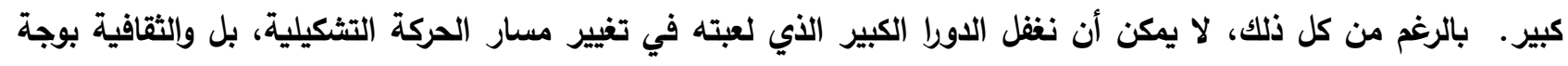

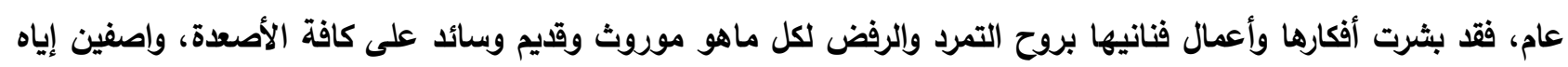

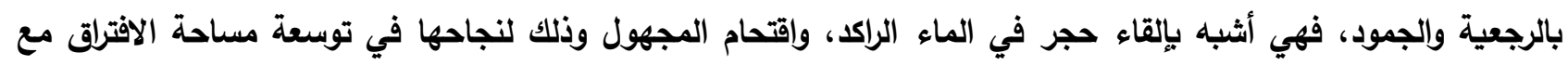

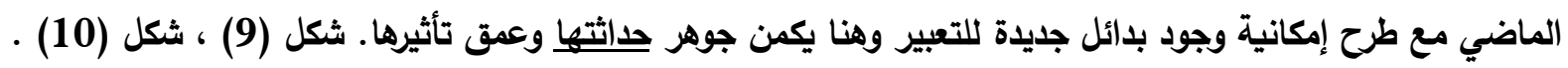

الأربعينيات:

"الم تكن حركات التمرد الأسلوبي والمفاهيمي في الفن لاتي جيل الأربعينيات... بمعزل عن حركات التحرر السياسي والنهوض الاجتماعي"45 وهكذا شهرت الأربعينيات تكوين جماعات أخري مثل جماعة الفن المصري المعاصر أمين شكل (11) وعبد الهادي الجزار وحامد ندا وسمير رافع وأحمد ماهر رائف وغيرهم، التي تبنت مبادئ جماعة الفن والحرية ولكن من منظور (محلي) فهاهم روادها يغوصون في الموروث الثعبي المصري ويستلهمون مضامينة ويحتفون بها في انحياز

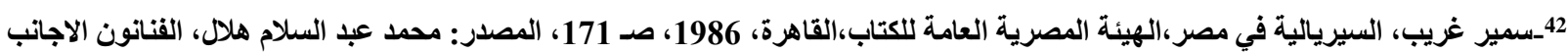

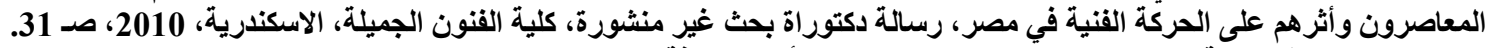
43 44 ـ عز ألدين نجيب، النار والرماد في الحركة التثكيلية المصرية، المجلس الأعلى للثقافة، 2013، 2013، ضـ 103. 
وتوجه اجتماعي واضح نحو الذوق والمزاج الجمعي المصري وبنية الثخصية المصرية في تناول حداثي جديد يثكل مزيجاً من التعبيرية والدادائية والسريالية والرمزية معاً (12) وقد "استبدلو مصادر الاوعي التي أرساها فرويد ويونج بعالم الاساطير

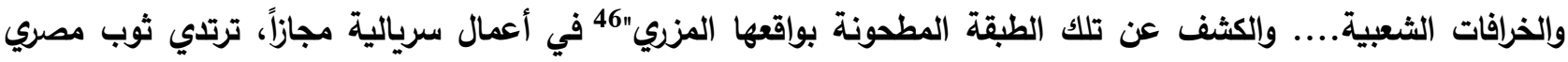
صميم وتحمل توجهاً نقدياً لاذعاً في ذات الوقت للأوضاع الاجتماعية السائدة، شكل (13) مما عزّضهم للصدام مع النظام القائم ومن ثم إغلاق أحد معارضهم والقبض على البعض منهم، مثل الجزار اللذي أصبح فنان الثورة هو وزملائه بعد عدة لتهل

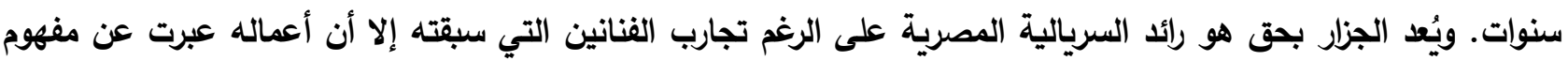

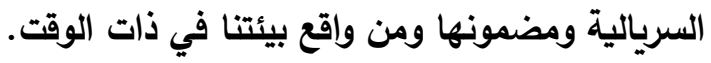
في نفس العام تكونت جماعة الفن والحياة أو الفن للحياة 1946 برعاية حامد سعيد وصوفي حبيب جورجي وغيرهم، والتي دعت لنفس التوجة بثكل آخر وهو الاستلهام من الفنون المصرية القديمة وماتبعها من ميراثنا الفني وإعادة توظيف أثكاله وتقنياته في أعمال حديثة وأكد على العلاقة الأصيلة بين الفن والحياة وضرورة اندماجهما والتعبير عن الطبيعة في صفائها

Amédée Ozenfant بحس صوفي وكان لاراسة مؤسسها في الغرب وزمالته للفنان العالمي إميديه أوزانفان ولوكوببوزيبه Le Corbusier أثر كبير على تبنيه للمفهوم الصفائية في الفن والصياة مطبقاً ذلك على حياته الثخصية التي

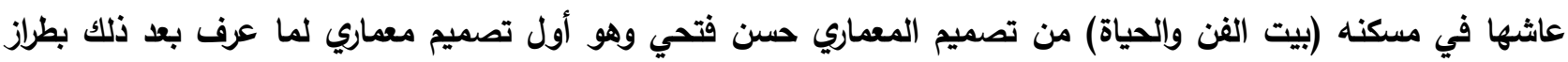

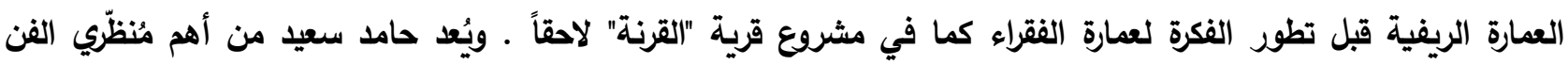
المصري الحديث وأغزرهم انتاجاً أدبياً. شكل (14) وهناك أيضاً جماعة صوت الفنان التي أسسها حامد عويس ذأداء ذات التوجه اليساري وصلاح يسري وصلاح عبد الكريم وغيرهم والتي أقامت معرضها الوحيد عام 1946.

في العام التالي 1947 تأسست جماعة جانح الرمال على يد فؤاد كامل والتى دعت إلى أسلوب تجريدي يخرج فيه الفنان الثحنة الانفعالية مباشرة على سطح العمل بضربات الفرشاة العنيفة والألوان الساخنة في تجربة جديد يمكن نعتها بالتجريدية

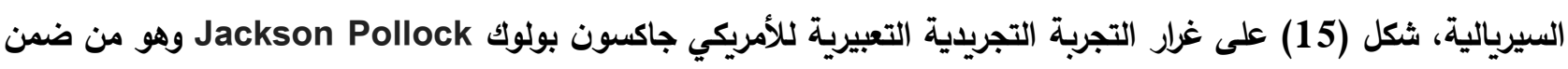
الاتجاهات المبشرة بفنون مابعد الحداثة في الغرب. تلاها في 1948 أسست جماعة الفن الحديث بعضوية جمال السجيني وصلاح يسري وحامد عويس ويوسف سيداه وجاذبية

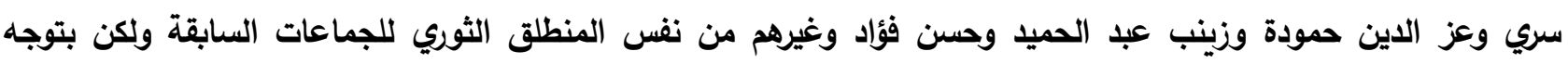

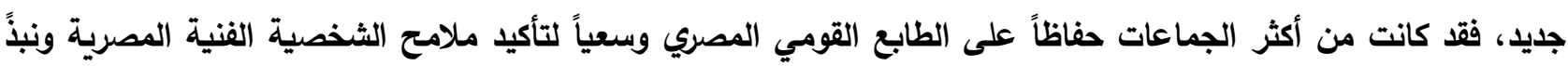

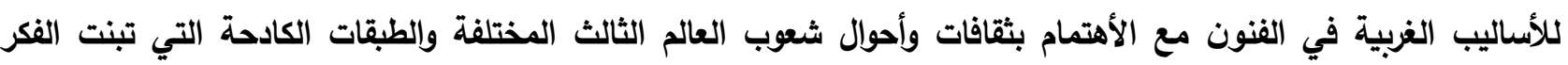

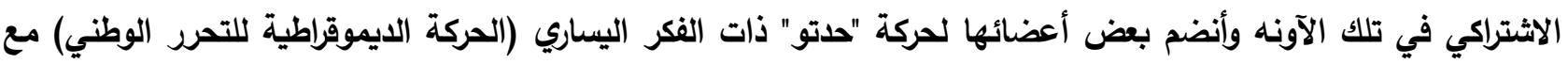

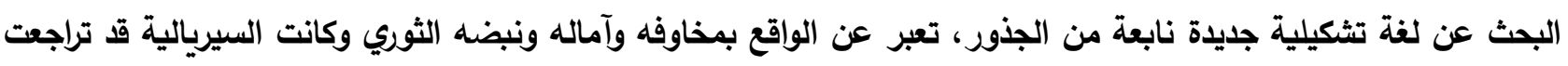

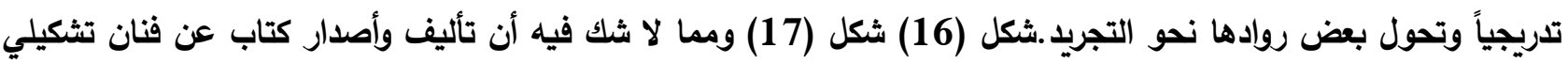
مصري لأول مرة عام 1949 (مختار: حياته وفنه) لبلر الدين أبو غازي، يعد نقلة نوعية في مكانة الفن التثكيلي في

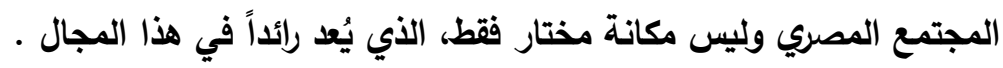

ويجدر بنا الأثارة هنا إلى الحدث الهام على الصعيد الفني وهو إنثاء مرسم الأقصر الذي أقترح محمد ناجي فكرته عام

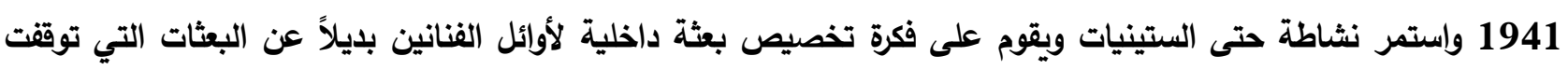

46 - إيناس حسني، جماعة الفن المعاصر ثروة باقية من الفن الجميل، سلسلة كتب بريزم للفن، العلاقات الثقافية الخارجية، وزارة الثقافة، مصر، 2009؛ 
إبان الحرب العالمية الثانية وقد أقيم في منزل الثيخ على عبد الرسول بالبر الغربي مكتشف الخبيئة الأثرية وتولى ناجي إدارتة ثم توالى بعده حامد سعيد والحسين فوزي وصلاح طاهر وعباس شهدي... إلخ وتخرج من هذا المرسم عدد كبير من

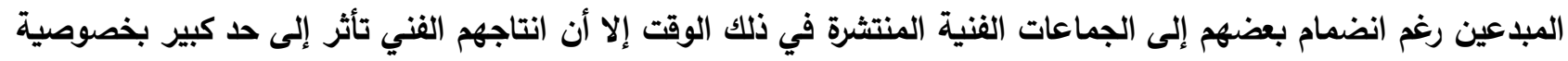
المكان وسحر وبيئة الجنوب وآثاره وترك بصمة فنية في أعمالهم المستقبلية. وهناك أيضاً مجموعة الفنانين الذين يمكن نعتهم

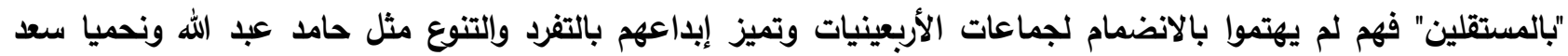

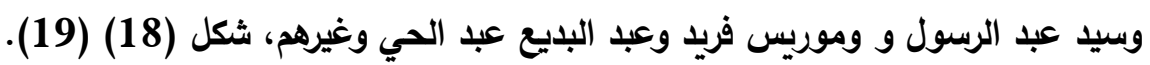
والثاهد هنا، ان فكرة تأسيس الجماعات الفنية (وهي فكرة منقوله عن الغرب) قد أستمرت على على مدار تاريخ الفن التهيد التشكيلي

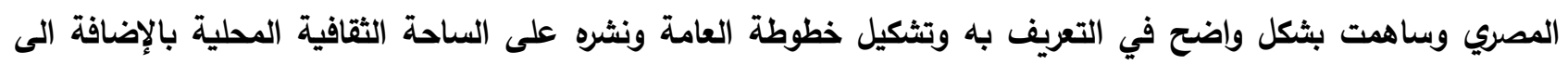

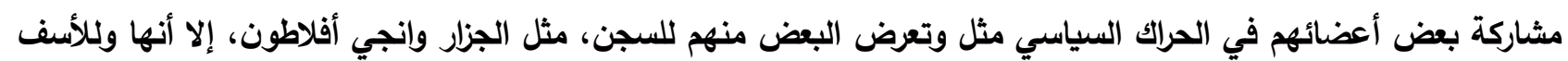

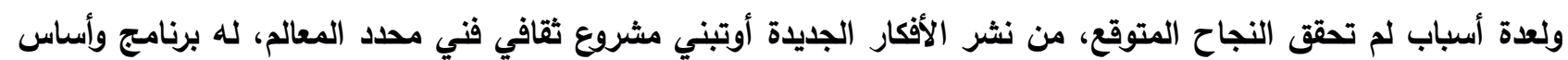

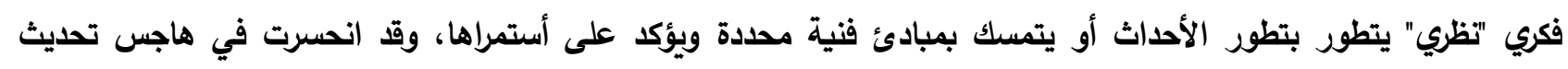
الثكل الفني التثكيلي فقط فلم يحدث التكامل اللازم بين فروع الفنون المختلفة وحركة النقد الفني لخلق نهضة حقئ حقيقية. أيضاً عدم وجود دعم مادي منظم لتلك الجماعات واعتمادها على الجهود الأتية لأعضاءها بالإضافة إلى طبيعة وهدف الجماعة وحته

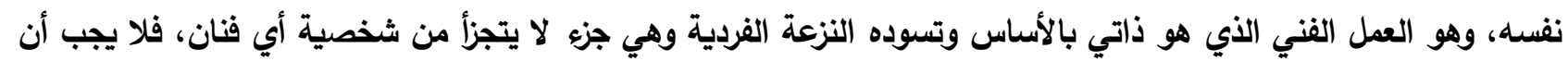

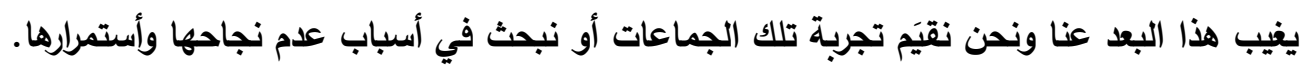

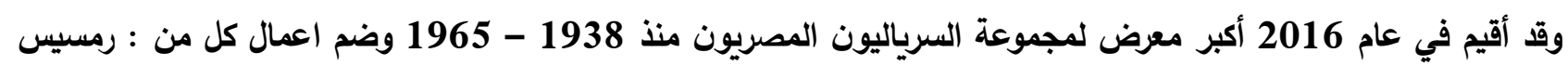
يونان، راتب صديق، سمير رافع، حسين فوزى، كامل التلمساني، فؤاد كامل، وأنور كامل وانجي أفلاطون، كمال يوسف، وفئ وباروخ

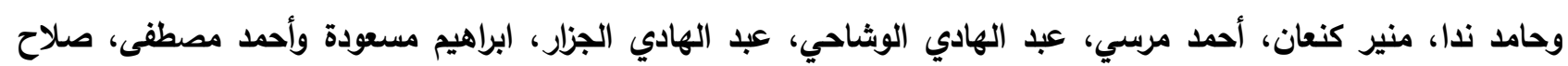

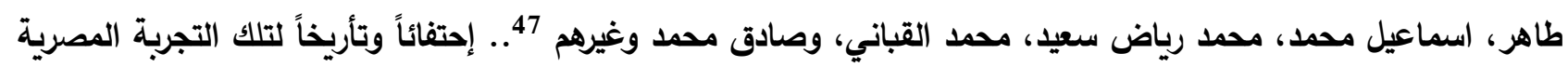

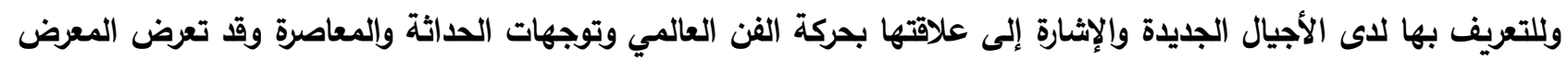

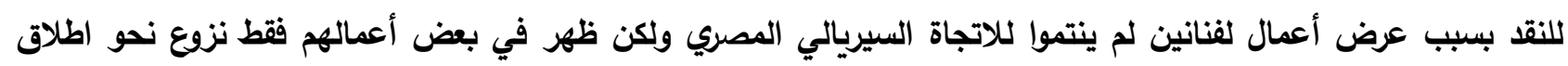
العنان للخيال.

الخمسينيات:

مثلت ثورة يوليو 1952 شرارة البدء في طور حضاري جديد إن جاز التعبير وعادت الأصوات تنادي بضرورة الالتفاف نحو مشروع قومي سياسي اقتصادي وثقافي، يبث الروح في مشروع النهضة المصري الذي بدأ مع بدية القرن وتعثر لأكثر من مرة.

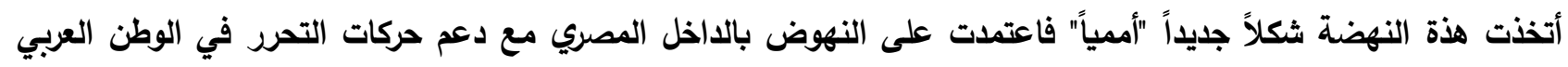

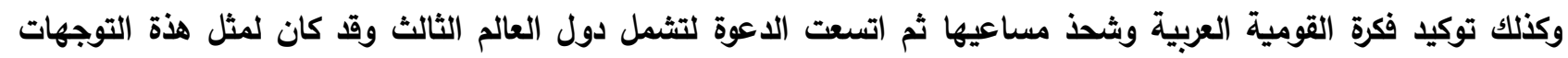
تأثير كبير على الثأن الثقافي المصري. في عام 1953 وفي خضم أحداث وتجليات ثورة يوليو، تأسست جماعة أتيلية القاهرة وهي من الجماعات التي استطاعت

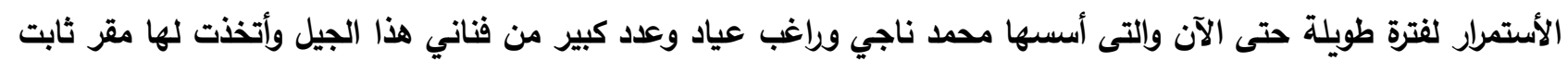
في وسط القاهرة، وكانت الحركة الفنية قد تثعبت إلى عدة اتجاهات، من الوقوف في معسكر الثورة والتعبير عن أفكارها وإنحيازاتها وتوجهاتها الأيدولوجية نحو المعكر الاشتراكي، بطريقة مباثرة أو الانغماس في الطابع المحلي والتعبير عن البيئة

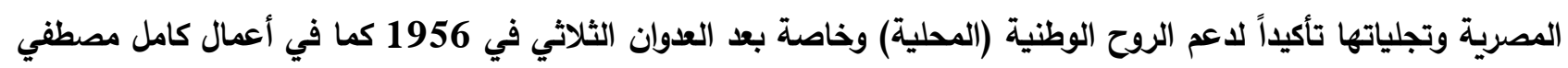

47 -http://sharjahart.org/sharjah-art-foundation/exhibitions/when-arts-become-liberty-the-egyptian-surrealists1938-1965. 
وعبد القادر رزق وسيد عبد الرسول وتحية حليم شكل التي تميزت أعمالهم بالصياغة الرمزية مع الحفاظ على الثكل والمضمون الواقعي الاجتماعي بوضوح (20) واستمرأعضاء الجماعات السابقة الأكر في الإبداع على نفس المنوال خلال الخمسينيات مثل الجزار وندا وسمير رافع وانجي أفلاطون شكل (21)، (22) (23) واستمر البعض منهم حتى نهاية حياته مخلصاً للتجربة السيريالية (الثعبية) التي تم تمصيرها مثل حامد ندا وسمير رافع وتحول بعضهم إلى التجريد مثل أحمد ماهر رائف.

سادت نهاية الذمسينيات وبداية الستينيات روح الحماسة الثورية والأمل المفعم بالحركة والنشاط في اتجاهات متعددة نحو بناء مجتمع حديث، وبالطبع كان لهذا التوجة أثر كبير على حركة الفن التثكيلي التي دعمتها الدولة بقوة، على سبيل المثال بدأت فعاليات بينالي الأسكندرية 1955 والذي أتاح الفيح الفرصة أمام الفنانين للتعرف على ابداعات الفنون الغربية الحديثة والاحتكاك

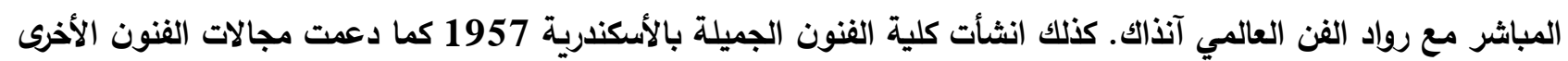
من مسرح وسينيما وتليززيون 1961 في إطار خطة شاملة للنهوض بالثقافة وربطها بخطط وأهداف الدولة.
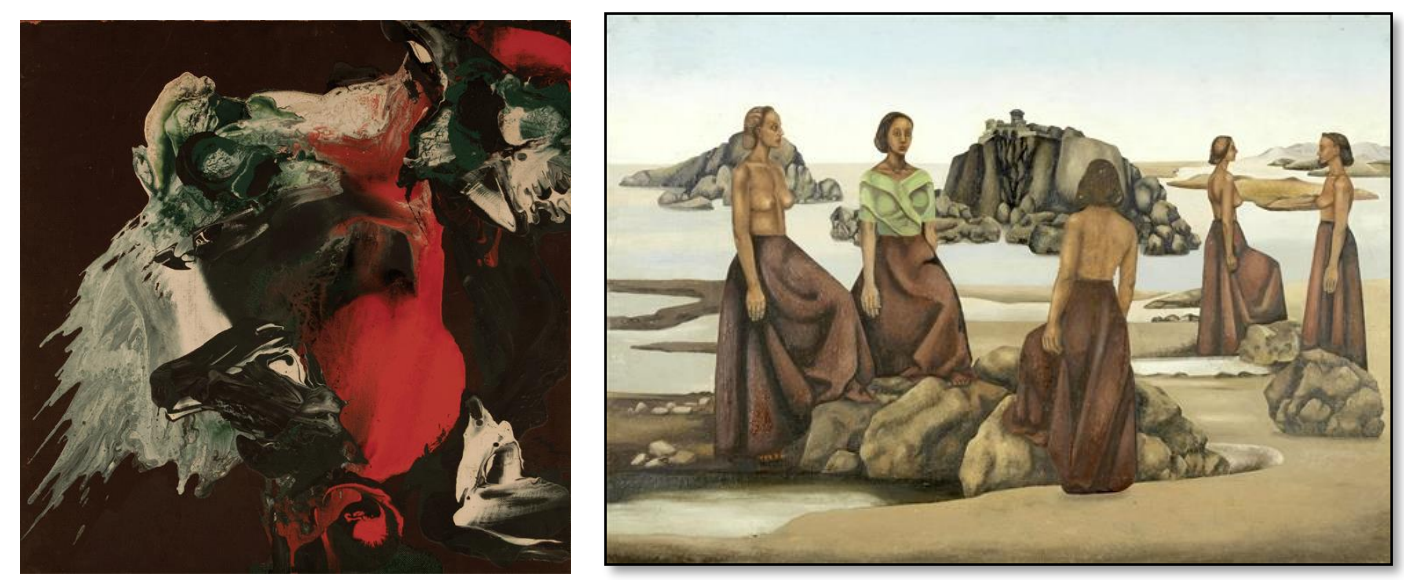

شكل 15- فؤاد كامل، تكوين، ألوان زيتية على

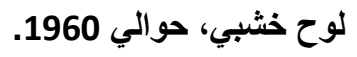
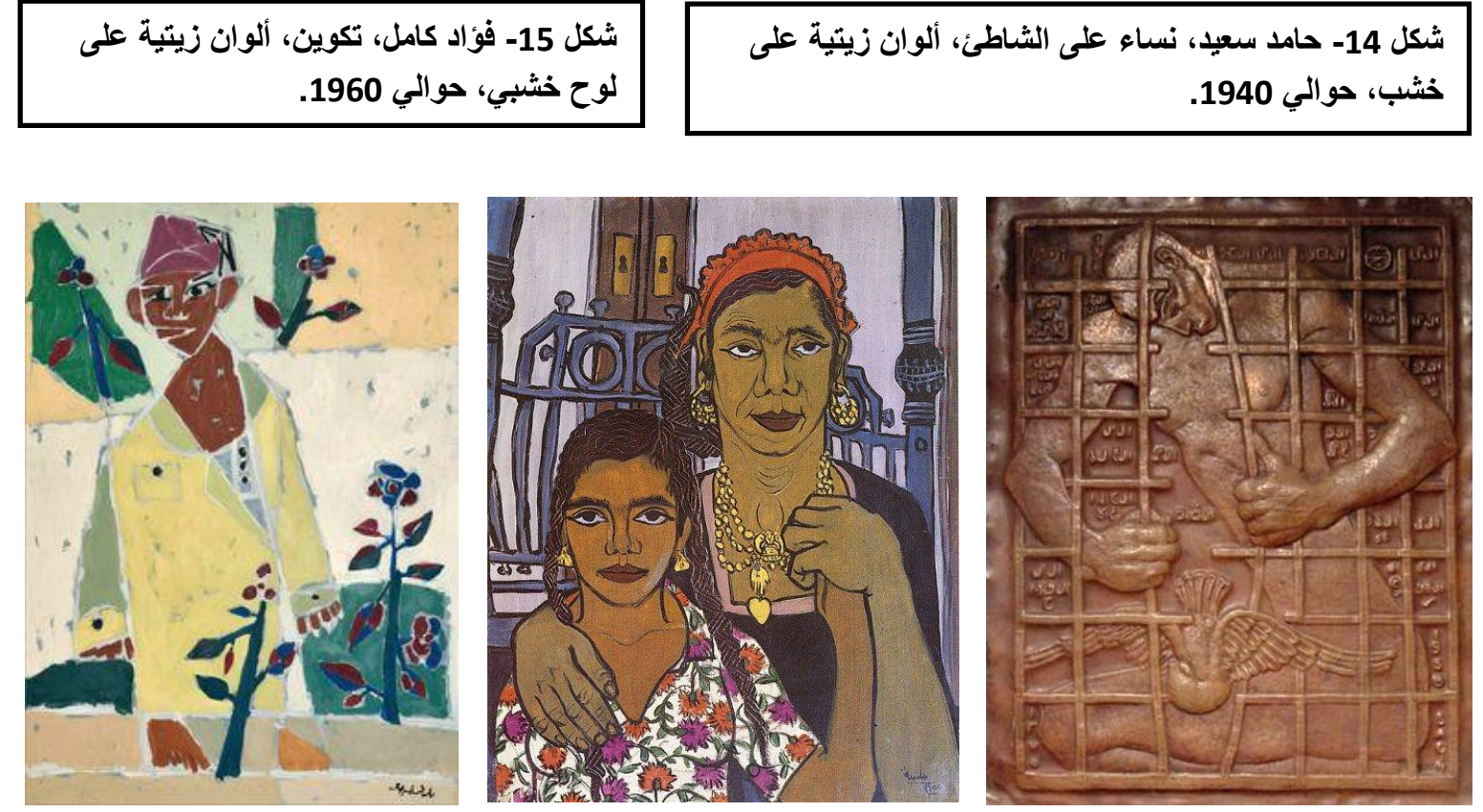

$$
\text { شكل 18- حامد عبد الله، ألوان }
$$
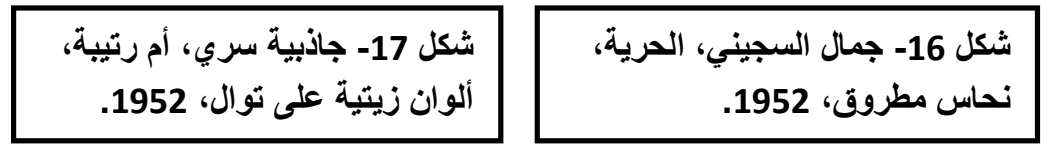


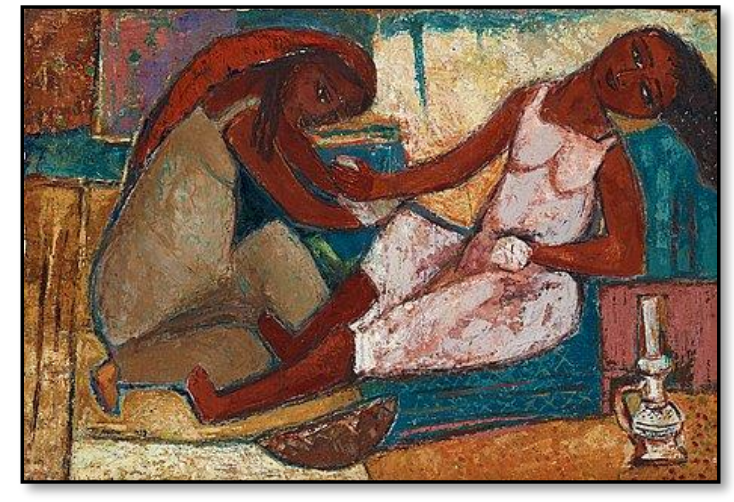

شكل 20- تحية حليم، ليلة الزفاف، ألوان زيتية على توال، 1959.

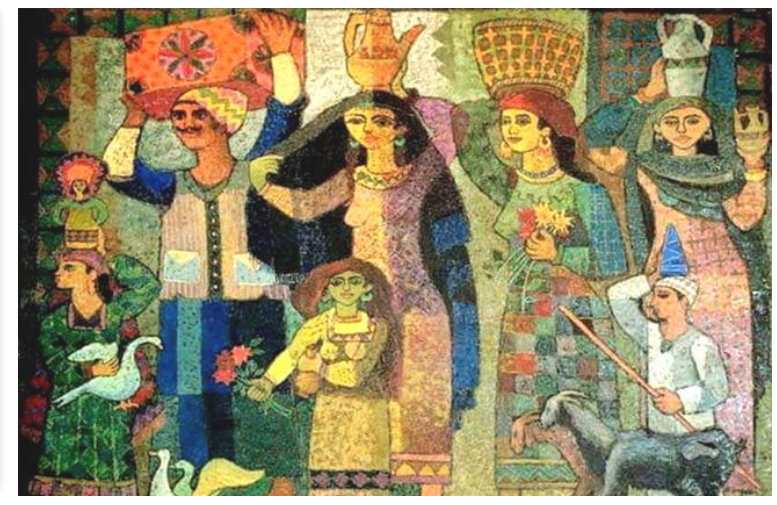

شكل 19- سيد عبد الرسول، الصباحية، ألوان زيتية على

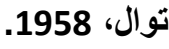
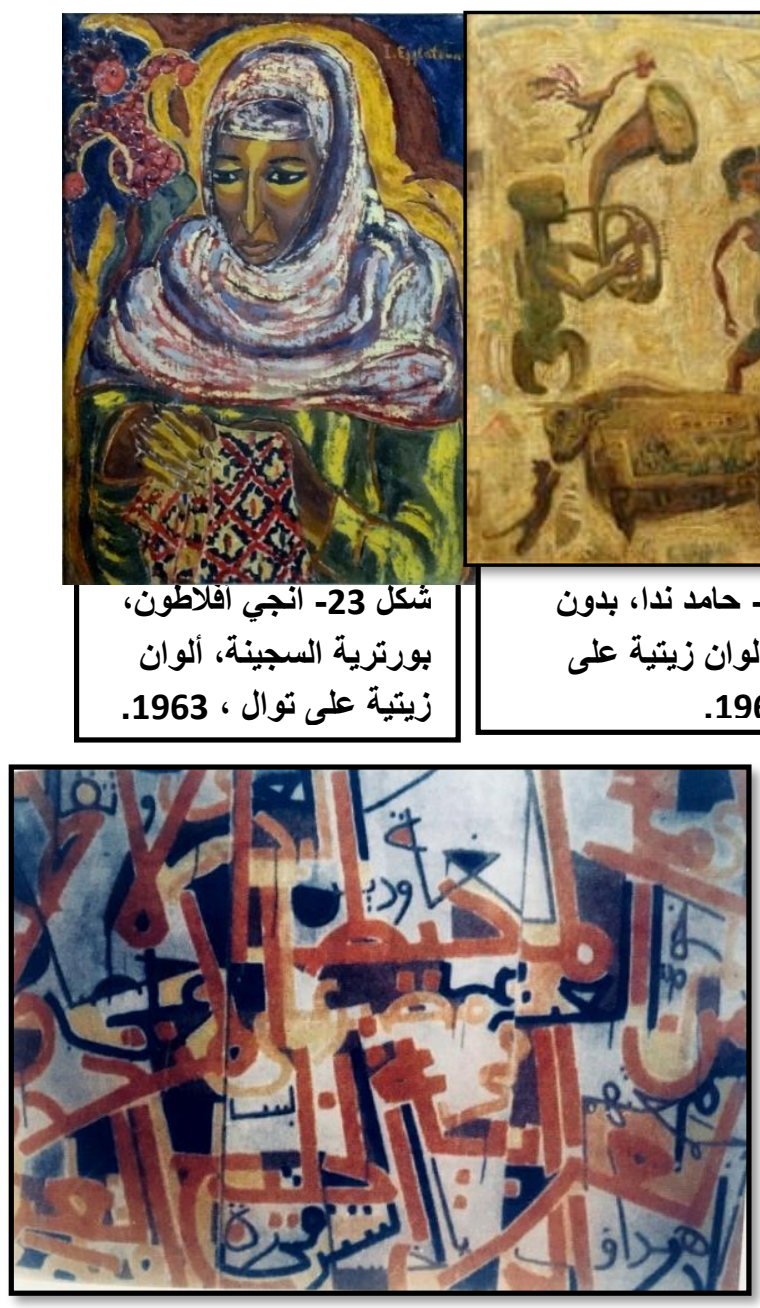

شكل 25- يوسف سيده، الوحدة العربية، ألوان زيتية على قماش، 1962.
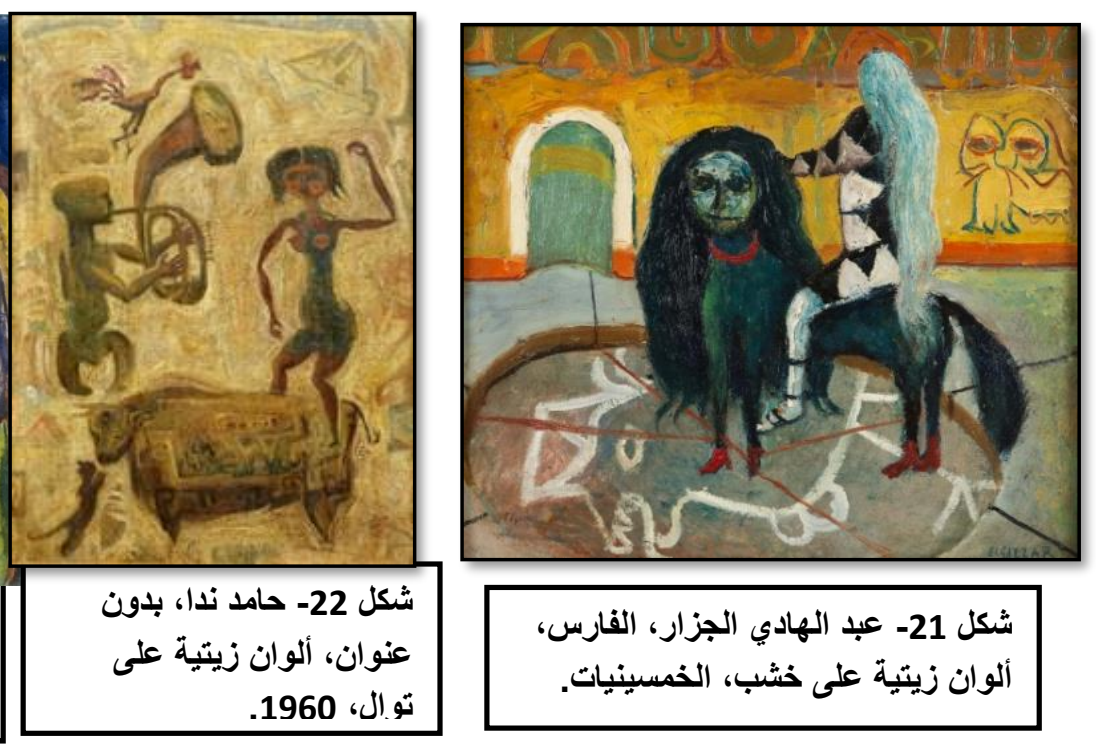

شكل 21- عبد الهادي الجزار، الفارس، ألوان زيتية على خثب، الخمسينيات.

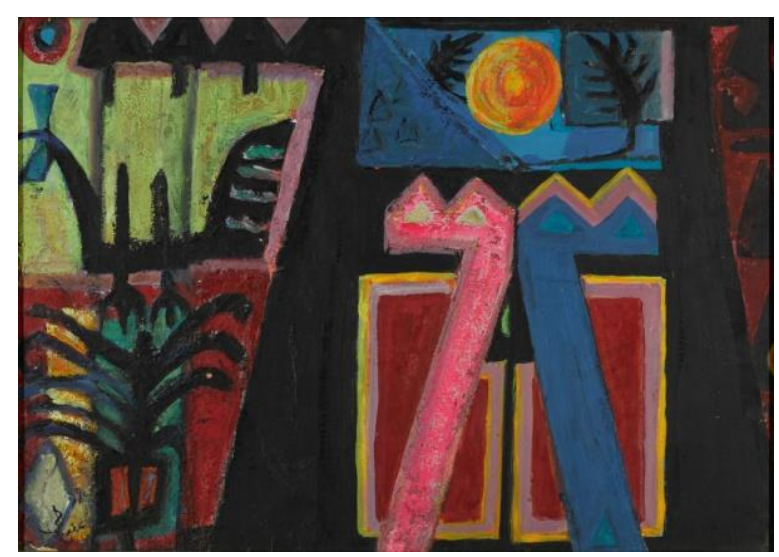

$$
\text { شثب، 24- عفت ناجي، النوبة، ألوان زيتية وأكريلك على }
$$




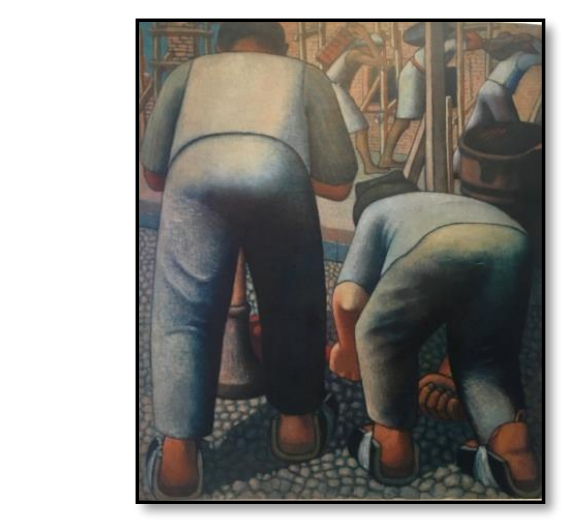

$$
\text { شوال، 27- حامد عويس، التعمير ، زيت على }
$$

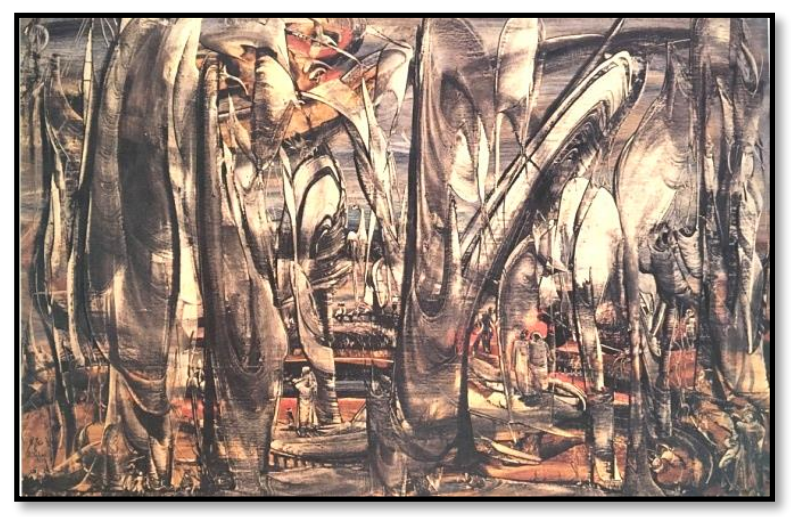

شكل 26- صلاح طاهر ، حوض النيل، زيت على توال، 1967.

اتسمت أغلب الأعمال في تلك المرحلة بالتعبير عن مفهوم الواقعية الاثتراكية وقيمة العمل والبناء والاعاية السياسية لمبادئ الوحدة والقومية العربية والمشروعات الكبرى كما عبر عنها خير تعبير محمد حامد عويس في تفاعلة مع قضايا العمل والطبقة العاملة وشحذه لروح العمل والبناء متأثراً بقواعد التكوين في الفن المصري القديم حيث الكتل الراسخة المتلاحمة والصفئ فئهاء اللوني والأطر المحددة للثكل و(الطاقة السكونية) على حد تعبير رضا عبد السلام، كما لا يمكن أن نغفل تأثره بالفن الغربي

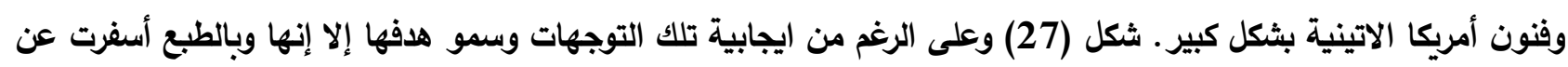
نوع من الالتزام الجامد أو قولبة الفن في قوالب محددة سلفاً، للتعبير عنها ولخدمة ألغيل أغراضها. على صعيد آخر، واصلت أيضاً مجموعة الحداثيين نشاطهم وهم جميع الفنانين اللذين وجدوا في الاتجاهات الغزبية ضالتهم

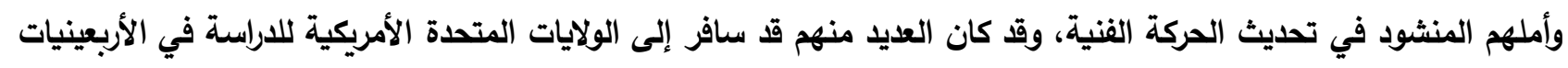

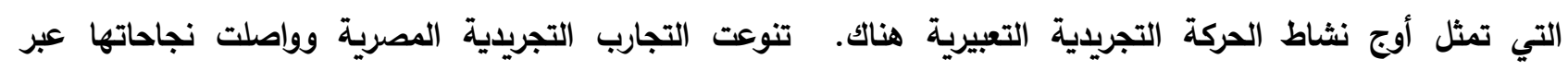
الخمسينيات والستينيات واستمرت حتى عصرنا الحالي، من تجريدية تعبيرية إلى تجريدية سيريالية إلى التجريدية الهندسية

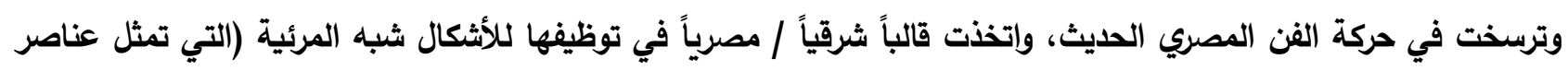

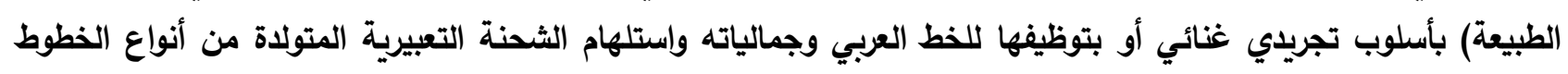

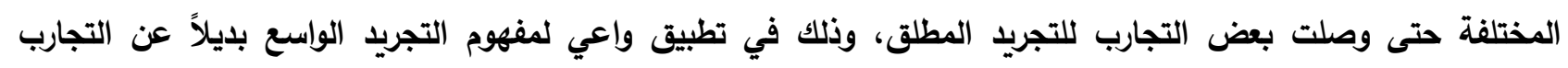

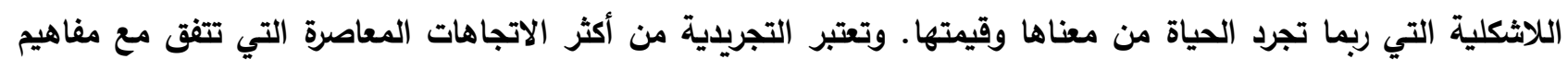
وواقع بئتنا الثرقية - المصرية، ولذلك نراها متواصله عبر الاجيال حتى وقنا المعاصر ، كما نثاهد في أعمال يوسف سيدئه وخديجة رياض وعفت ناجي وحمدي خميس وأحمد ماهر رائف ويليهم على نفس الدرب مصطفى الارناؤوطي وأبو خليل لطفي

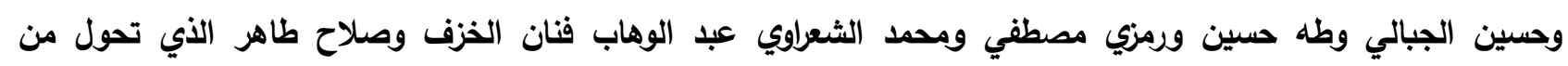
الاكاديمية إلى التجريد الغنائي الديناميكي والمطلق أحياناً الذي تبني قناعة "التسليم بوجود حقيقة لا تشبه الأثشياء ولا تحاكي

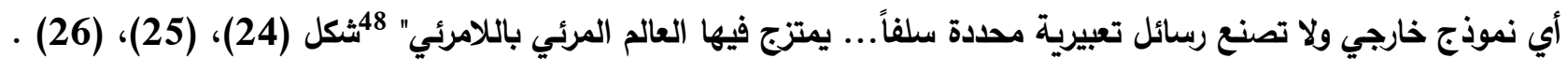

هكذا يمكنتا الإقرار بأن أعمال هذا الجيل (جيل الوسط من الثلاثينيات حتى منتصف الستينيات) تدخل في إطار التفاعل مع

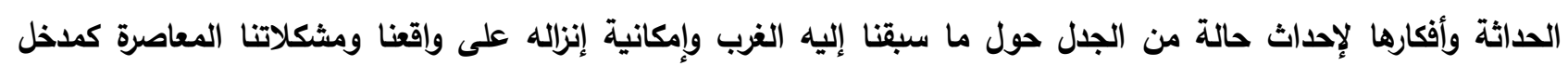

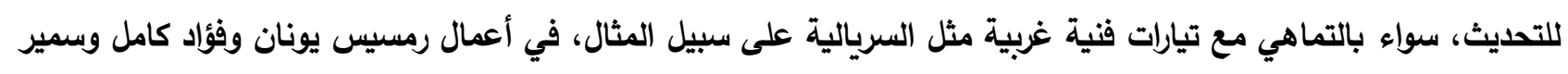
رافع أو بالإغرلق في المحلية وإلغوص في ثقافتنا الثعبية والميثولوجيا المصرية تأكيداً لهويتنا، كما في أعمال سيد عبد الريلية الرسول 
وعفت ناجي وعبد الهادي الجزار وحامد ندا وجاذبية سري وغيرهم مع اختلاف أساليبهم الفنية مع نزوع البعض منهم نحو

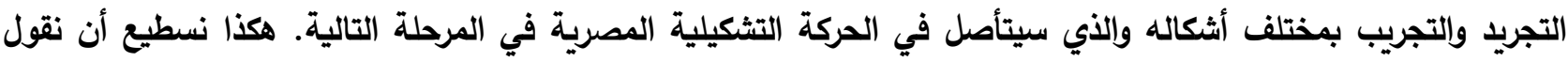
بحق انها سنوات المخاض الطويل التي سبقت ثورة يوليو ثم عايشتها وتبنت مبادئها السياسية والاجتماعية وتأثرت بإخفاقاتها، ونجاحاتها وقد مهدت الطريق للفن التشكيلي المصري نحو الحداثة والمعاصرة شكلاً ومضموناً. وأن جميعها كانت محطات هامة في التاريخ المصري الحديث وكان لها تأثير مباشر على الوجدان الجمعي وعبر عنها الفنانين بأشكال مختلفة، امتزجت فيها "الأساليب الفنية الأوروبية مشبعاً بمفاهيم القومية والوطنية مردداً أصداء تلك المعزوفة التي نبعت من أعماق المجتمع لا من فئرئ صفوته المثقفة وحسب" (49

\section{الستينيات والسبعينيات:}

إن القيمة الحقيقية لتلك التجارب الجماعية السابقة هو ذلك الطريق الذي مهدته للأجيال التالية وأسفرت تجربتها عن "امتلاك الوعي والرؤى والأساليب، فإن عقد الستينيات يمثل مرحلة النضج والازدهار في تطور هذة الحركة."50 تلك الحقبة التي يطلق عليها خالد البذادي (سنوات الممر) حيث كان للجيل الثالث وتفاعله المباشر مع الأحداث السياسية في حقبة الستينيات عظيم الأثر على حركة الفنون التثكيلية المصرية، بدءاً من الانفصال عن سوريا 1961 ثم قرارات يوليو 1961 وإقرار "الميثاق" 1962 الذي أصبح بطلاً وشعاراً للمرحلة شكل (28) والذي نجد في بابه الأول تحت عنوان (نظرة عامة) عبارة داله على توجه حداثي جديد، في الفكر السياسي- إلا أنه ظل عبارة مكتوبه ولم يخرج إلى حيز التطبيق بعد، من وجهة نظر الباحثة- جاء فيها أن هذا العمل العظيم تحقق بفضل عدة ضمانات منها أنه تعامل "بفكر مفتوح لكل التجارب الإنسانية؛ يأخذ منها ويعطيها، لا يصدها عنه بالتعصب، ولا يصد نفسه عنها بالعقد"51 في اتساق مع ثقافة الخطابة الرنانة والبروباجندا التي ميزت تلك

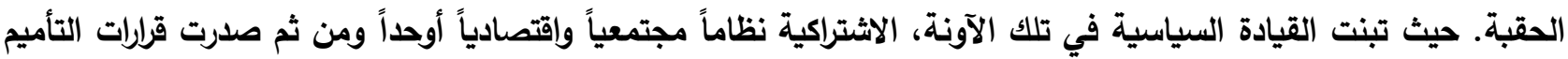
وتلتها ملحمة بناء السد العالي التي تفاعل معها الفن التشكيلي بصورة هائلة كما نرى في أعمال سعد الخادم وعفت ناجي وحامد عويس ومحمد صبري وانجي أفلاطون صاحبة فكرة تسجيل تلك الملحمة تثكيلياً والتي مجدت مثاليات المرحلة شكل (29)، (30) (31) أوالجزار والحسين فوزى وغيرهم اللذين تأثروا برؤية تلك الآلات العملاقة ومعدات التصنيع وحركة البناء المستمرة التي كانت مقدمة لنهضة صناعية كبرى في أواسط الستينيات فاختفى البطل (التشخيص) في أعمال بعضهم وحلت محله الآله التي ذاب الفرد داخل حركتها الدهوب. شكل (32).

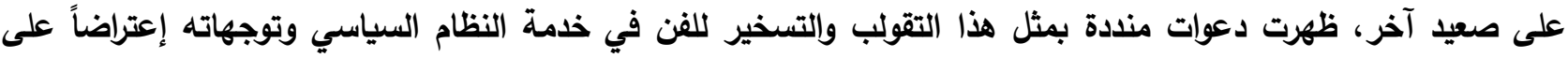
تقييد حرية الفنان وتقويض حركة الإبداع وتأثرت تلك الأصوات بأفكار المعكر الغربي الرأسمالي (الولايات المتحدة وحلفائها) وتوجهاته المعلنة نحو مزيد من الحرية والتعبير عن الذات وعن المجموع (الفن الجماهيري) (الفن للفن) وماشابهها من دعوات

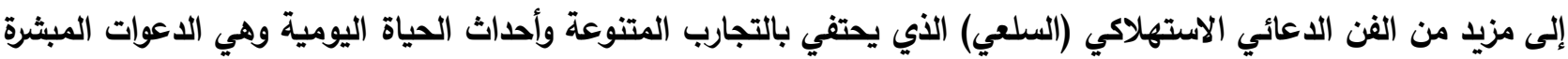
بثقافة مابعد الحداثة.

لقد كان لهذا الانفتاح على العالم الخارجي بقطبيه أثثرإيجابي على حركة الفن التشكيلي بوجه عام واستطاع عدد من الفنانين

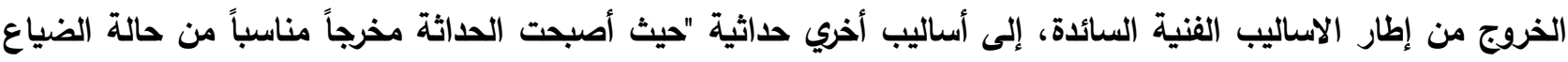
التي سقط فيها جيل الثورة والأجيال التالية له"52 مثل الفنانين صلاح عبد الكريم (فنان الايكور والتصوير والنحت) ومنير كنعان

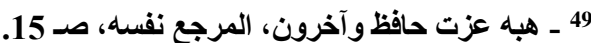
50 ـ هبه عزت حافظ وآخرون، الحركة الفتية التثكيلية المصرية (الستينيات والسبعينيات) ثلاثة دراسات، المجلس الأعلى للثقافة، لجنة الفنون التشكيلية، القاهرة، 2010، صدئ صد 15. http://nasser.bibalex.org/Speeches/browser.aspx?SID=1015\&lang=ar 51 ـ وثيقة الميثاق. 52 ـ هبة عزت الهواري، الهوي، تحولات التشكيل المصري المعاصر، 1967 - 2011) مرجع سبق ذكره، صـ 43. 
وسعد الخادم وعفت ناجي وصبحي جرجس وصبري ناشد وفاطمة العرراجي وآدم حنين على سبيل المثال في أعمالهم التي استخدم فيها الأول -ععبد الكريم- "الخردة" في إبداع أعمال النحت لأول مرة في الفن المصري ويبثر بتوجه مابعد حداثي لاحق، فهو خليطاً بين مفهوم العمل المركب والفن الفقير وفن الخردة ويشير إلى تأثرة برواد الجماعات الفنية في أعمالهم الحديثة، مثل الجزار على سبيل المثال في مرحلة الإنسان والآله. حيث وظف الفنان قطع الخردة من معادن وأسلاك ومسامير وتروس ...إلخ في إبداع أعمال فنية تصور حيوانات وطيور على هيئة وحوش أكسبها التثكيل المفرغ بالخردة والاختيار الاقيق للأجزاء الدالة على أعضاء أجسامهم، حس ميكانيكي وروحاً نابضة بالحياة وتعبيراً صادقاً عن فطرية الطابع النفسي وهئ

أما الثاني منير كنعان، فقط أستخدم وسيط الكولاج في لوحات تجريدية وهو يُعد "أحد أفراد الطليعة التي وضعت حداً.. لسيطرة اللوحة التمثيلية.ذذات المقاسات الصالونية. واستخدام أثياء عديدة كانت مهملة"53 ويمكنتا أعتبار تجربة الفنان تمثيلاً صادقاً لاتجاه الحداثة، بجرأتها واقتحامها هذا العالم الجديد وبسطوة التجريب التي رافقته طوال مشوارة الفني. وظف الفنان عناصر مثل وأل الكرتون والأسلاك وخشب النوافذ والأبواب القديمة والخيش في تكوينات تجريدية تشي بعلاقات حميمية مع البيئة المصرية

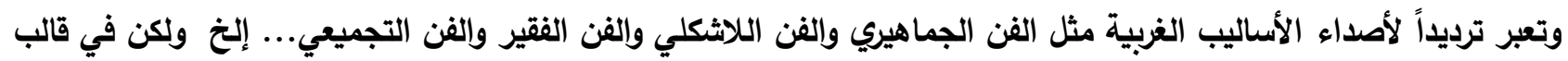

محلي،شكل(34). تأسست في بداية الستينيات جماعات فنية أخرى مثل جماعة الفنانين الخمسة عام 1962 وضمت في عضويتها عبد الحميد الدواخلي وفرغلي عبد الحفيظ وعلى نبيل وهبة ونبيل الحسيني ورضا زاهر، في محاولة لإحياء قيمة الجماعات الفنية في الأربعينيات إلا انها لم تكن قائمة على أهداف محددة واستمرت في نشاطها حتى عام 1968 مايزال أهم أعضائها (فرغلي) يقدم ابداعاته التثكيلية الداثية التي تتميز بالخطوط والاثكال البسيطة العفوية التي تسبح على السطح في خيال بين التجريدية والرمزية باحثة عن الطاقة الروحية وكذلك اقتحامه لمجال الإنثاء في الفراغ في أعمال تحمل قيماً مفاهيمية. (35). أيضاً في عام 1964 تأسست جماعة فسيفساء الجيل برعاية الفنان عمر النجدي الجرافيكي ذو النزعة التصويرية والذي وظف فئه

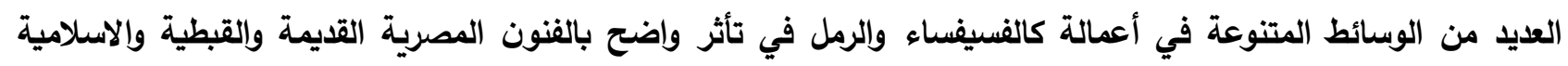

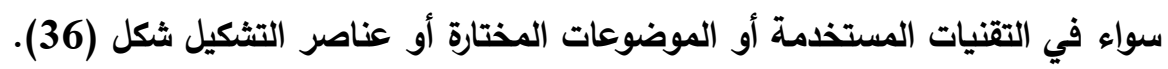

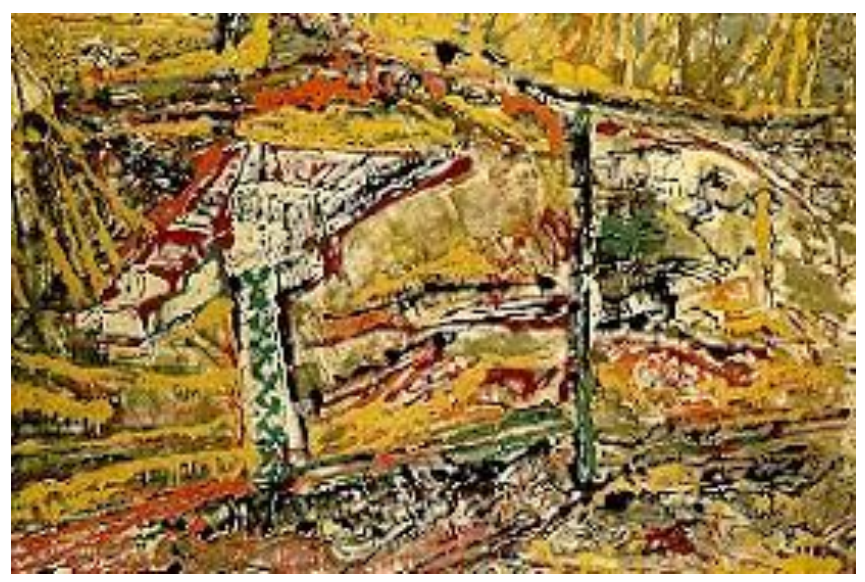

شكل 29- سعد الخادم، موقع بناء السد العالي، ألوان زيتية على النى ورق، أوائل الستينات.

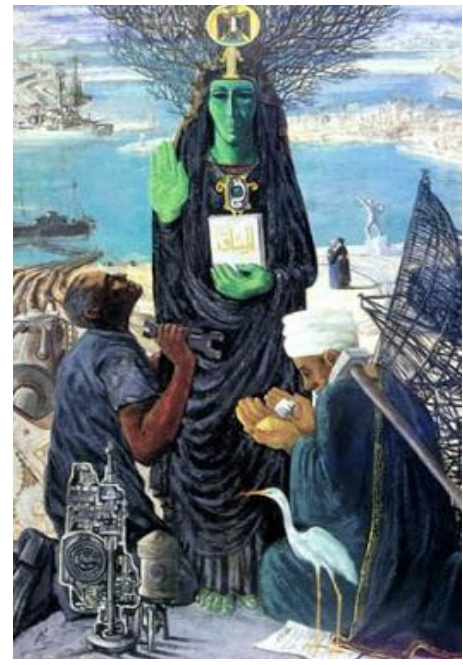

شكل 28- الجزار، الميثاق، ألوان زيتية على خشب، 1962.

53 ـ للمزيد أنظر: محمد حمزة، الصعود إلى المجهول (طريق التجريدية) الجمعية المصرية للنقاد بالتعاون مع الهيئة العامة للكتاب،(الكتاب العاشر)1997. 

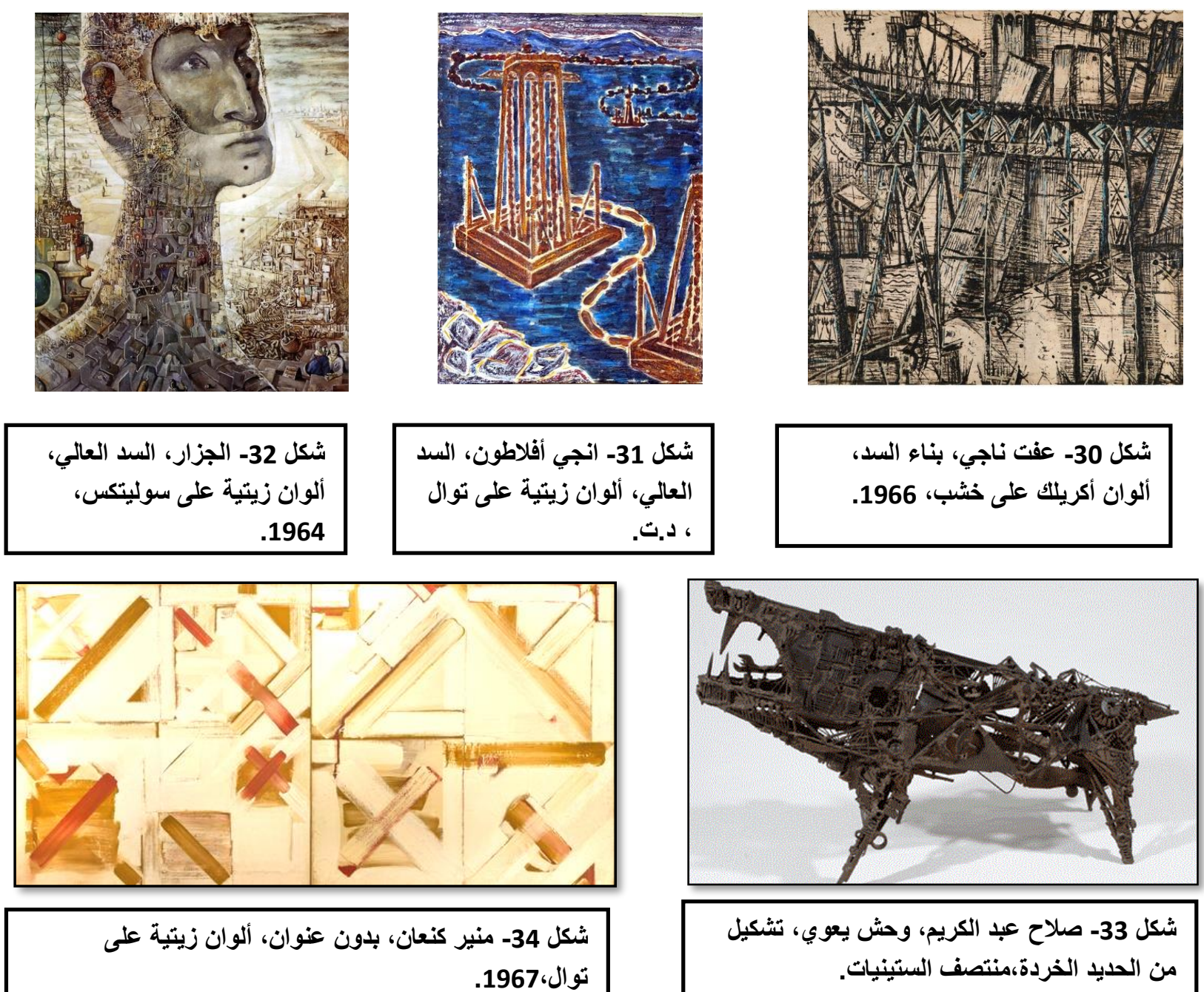

شكل 33- صلاح عبد الكريم، وحش يعوي، تشكيل

من الحديا الخردة،منتصف الستينيات.

في العام التالي تأسست جماعة التجريبين 1965 التي لم يكن لها من اسمها حظاً وفيراً في التجريب بمعناه الدائثي الغربي

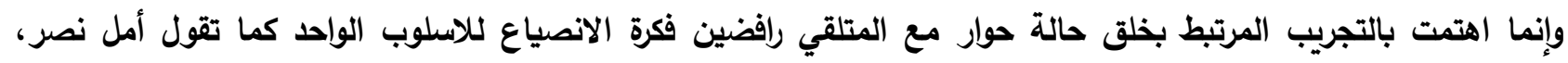

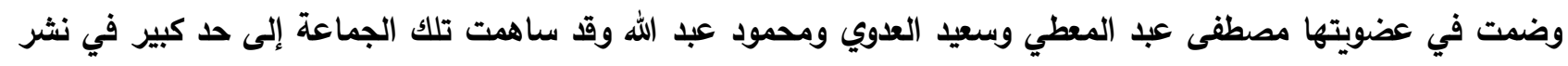

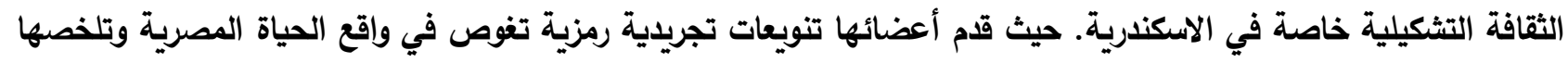

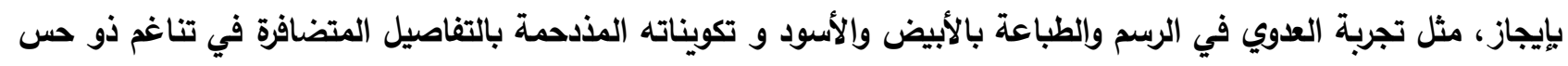

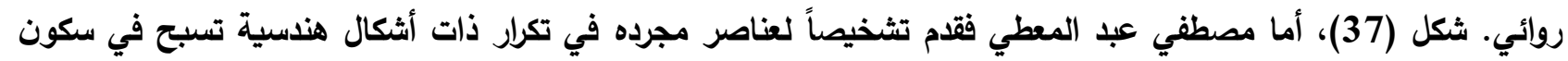

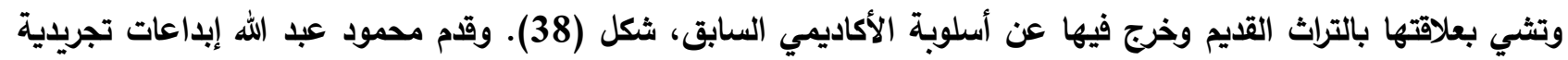

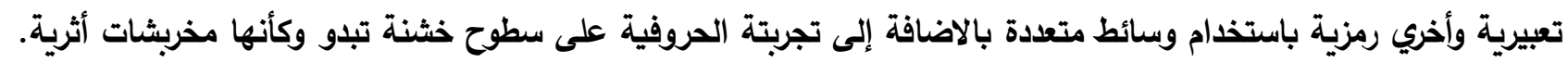

شكل(39)

إن ما ميز تلك الفترة أيضاً النشاط المكثف لعدد من فناني التجريد من هذا الجيل مثل عبد الوهاب مرسي وطاهر وكنعان

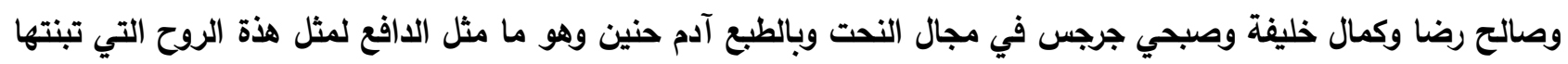

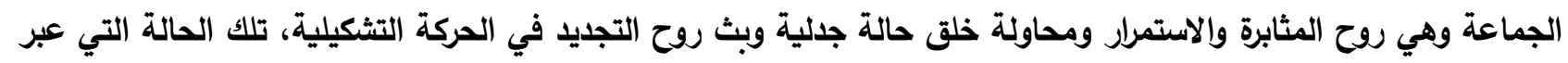

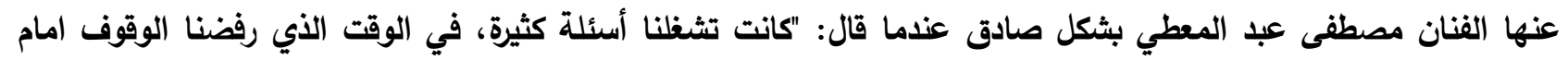

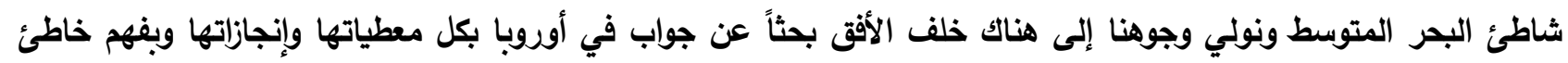

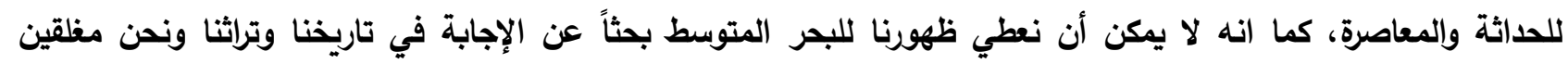


العيون والعقول عن عصر نعيشه وقد سبقنا فيه العالم في مجالات كثيرة، وهل الجواب في أن يكون للفنان أسلوباً ولزمات

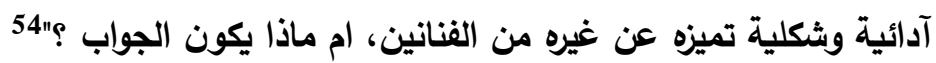
ثم جائت هزيمة يونيو 1967 وقد أحدثت صدمة بالغة في الوجدان المصري والعربي تلتها حالة عامة من الانسحاب والصمت ألته لاى أغلب الفنانين التثكيلين، وظل عدد منهم حبيس دائرة التكرار وحبيس ذاته المهزومة التي تعاني من مرارة الاغتراب

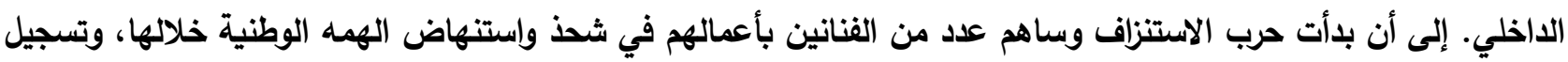

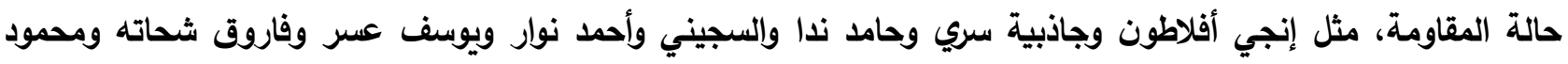
بقشيش وعز الدين نجيب وصبري ناشد وفتحي أحمد وغيرهم، شكل، (40)، (41) إلى أن جائت وفاة عبد الناصر المفاجئة

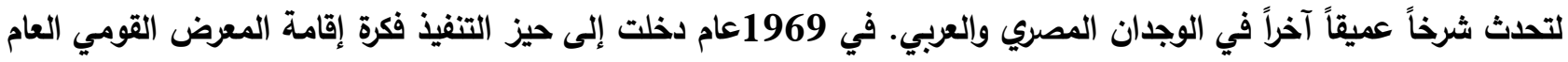

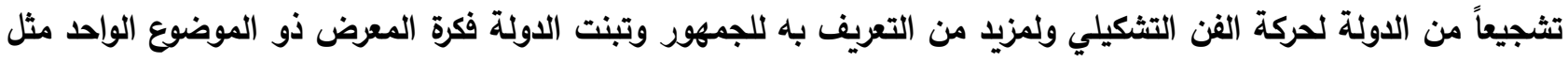

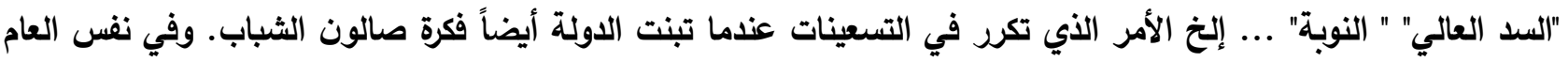
تأسست جماعة أخرى أخذت منحى مخالفاً للتجريبين وهي جماعة الفن والأنسان وتأثرت إلى حد كبير بجماعة الفن والحياة لحامد سعيد واستمر نشاطها لما بعد حرب 1973 وضمت في عضويتها أحمد عزمي وفاروق شحاتة وعادل المصري.

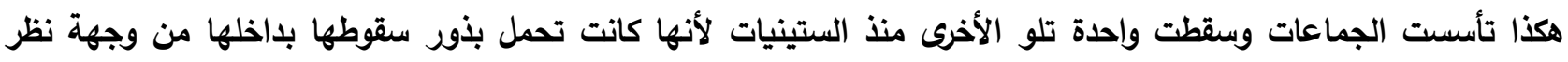

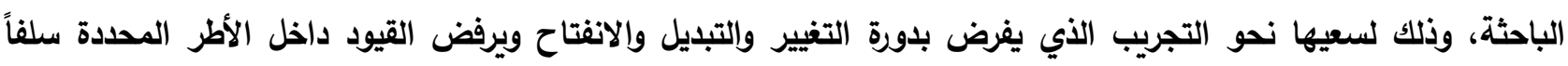
سواء من المؤسسات بكافة أثكالها أو من المجتمع أو الجماعة ذاتها وأرى أن في سقوطها ما يثير إلى مدي تحررها وحداثتها. مع تولي السادات سدة الحكم وإقرار دستور 1971 وما تلاه من حراك اجتماعي تمثل في المظاهرات والاحتجاجات على تأخر

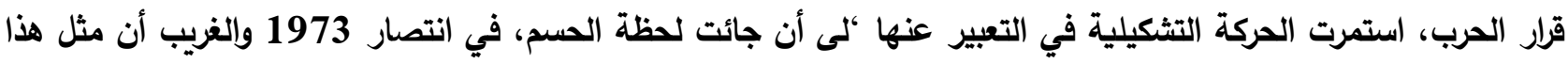
العدث العظيم لم نجد له مردود يوازي قيمته من أعمال فنية تثكيلية، سواءً بالكم أو بالكيف المتوقع، فأغلبها تُعد أعمال

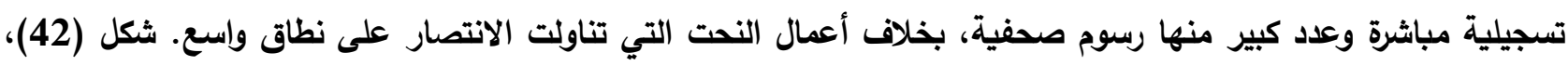
(43) ومن أهمها عمل الفنان سامي رافع (النصب التذكاري للجندي المجهول) شكل (44) والتي نجح فيها الفنان في الامج بين اتجاة التجريد والرمزية والحروفية في قالب مصري صميم. الجدير بالذكر هنا أن الدولة قد أولت أهتماماً بالفنون في تلك الكان

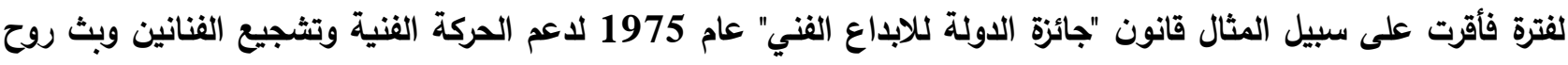
نهضوية جديدة تتفق وروح الانتصار الكبير مما سيكون له أثر هام الحركة التثكيلية لاحقاً. شكّل الانتصار بداية لمرحلة

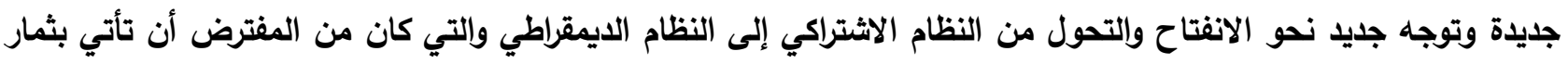

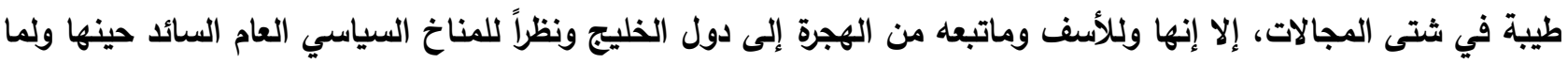

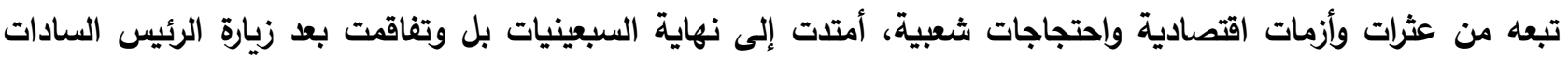

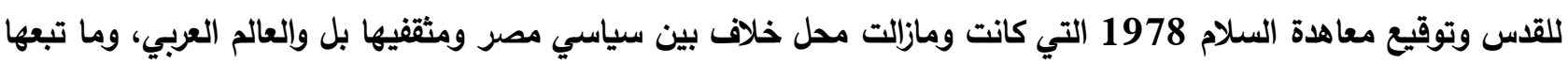
من مقاطعة الدول العربية لمصرومحاولة تقزيم حجمها وريادتها في المنطقة. أسفر هذا المناخ المأزوم عن حالة من العزلة بين الفنان والمجتمع، حيث أخذت التجارب الحداثية أبعاد ومناحي مغايرة عن ما أعتادت عليه الساحة الفنية وبالتالي أثارت

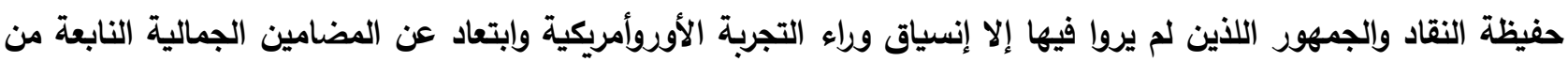

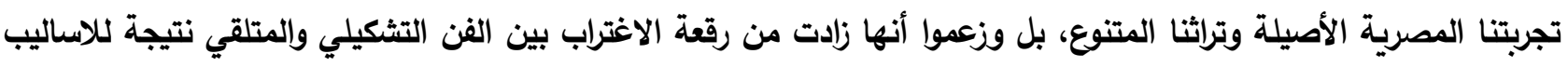

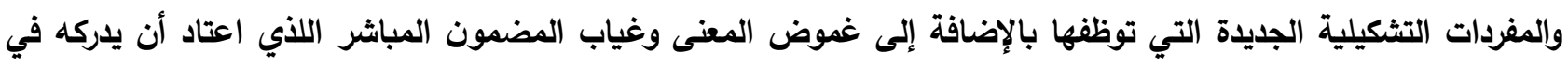
أعمال اللوحة والتمثال التقليدية.

54 ـ مقال سيد هويدي ، سقوط الجماعات في مصر : روح الفريق وسبل المثاركة في العمل- قيم غائبة، مرجع سبق ذكره. 
ومن الضروري الاثارة هنا أن هناك مجموعة من الفنانين ظلت بعيدة عن دائرة الاستقطاب هذة وتلك، وتميزت أعمالهم بالجمع بين الصفائية والبنائية في الاسلوب الفني والتناول الاكاديمي أحياناً، خاصة في أعمال الصور الثخصية، مع توظيف العناصر

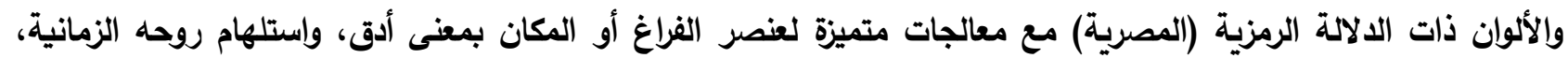

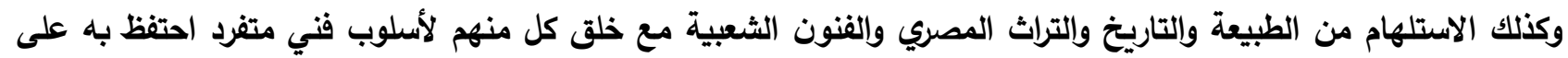

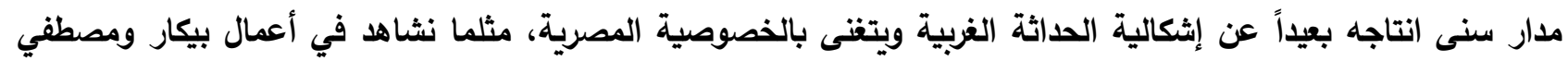
أحمد وحسن سليمان وحسني البناني وعزالدين حمودة وزينب عبد الحميد وممدوح عمار وزكريا الزيني وجورج البهجوري وعبد الهادي الوشاحي وعبد العزيز درويش على سبيل المثال لا الحصر شكل (45)،(46).

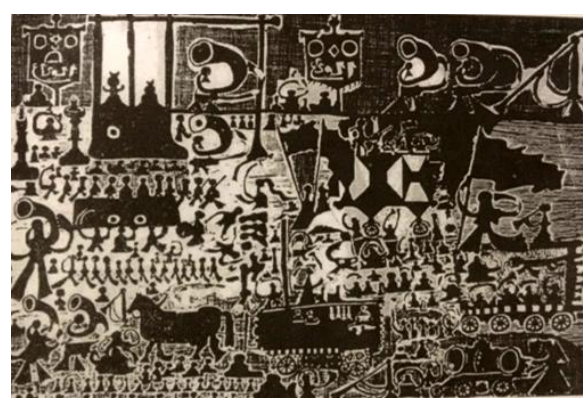

شكل 37- سعيد العدوي، جنازة جمال عبد الناصر، رسم حبر على ورق، 1971.

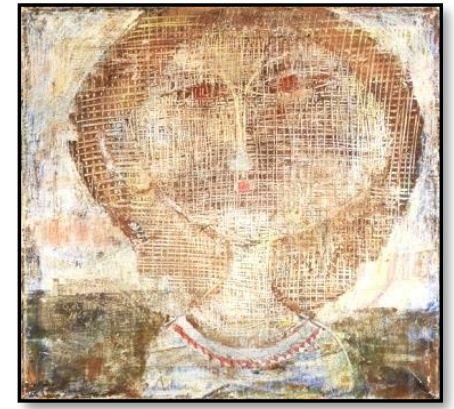

شكل 36- عمر النجدي، وجه

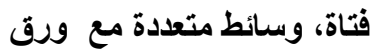
ذهب ، 1969.

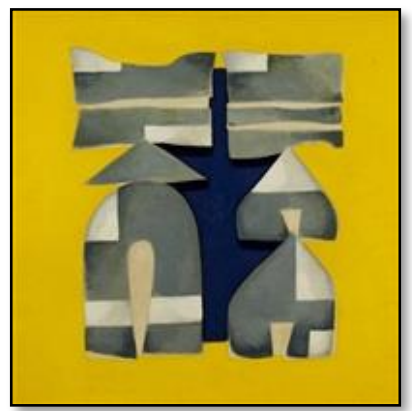

شكل 35- فرغلي عبد الحفيظ، بوبدون عنوان، ألوان زيتية على على

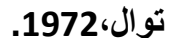

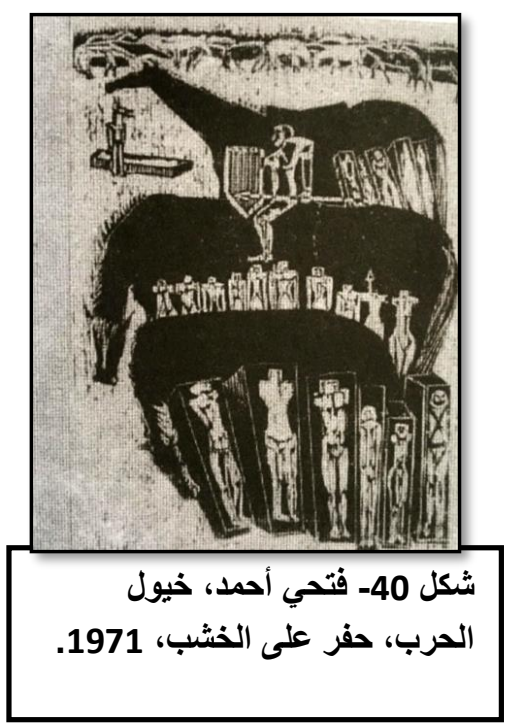

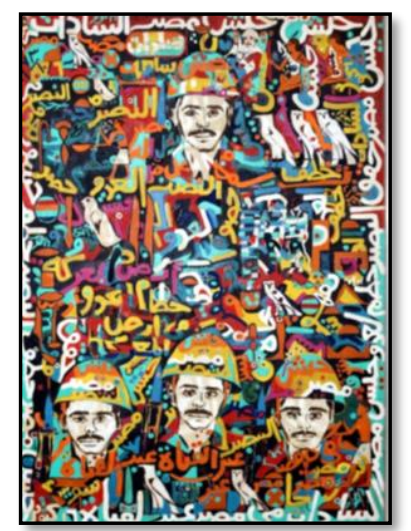

شكل 43- ملحمة أكتوبر، يوسف سيده،ألوان زيتية على توال،1973.

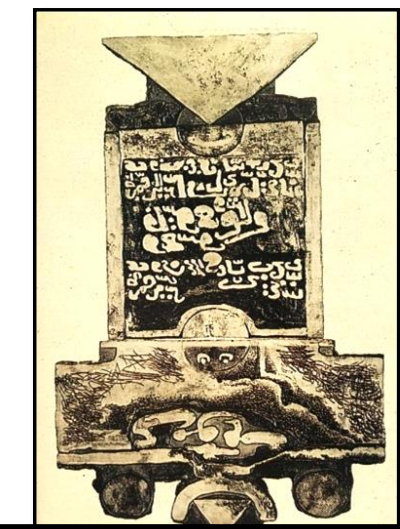

شكل 39- محمود عبد الله، بدون عنوان، حفر على زنك، أواخر السبعينيات.

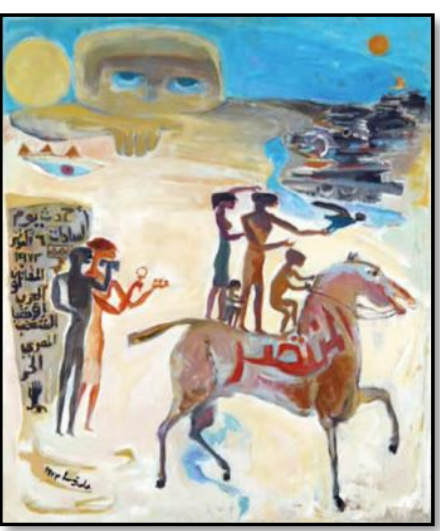

شكل 42- حامد ندا، المنتصر، ألوان زيتية على خشب، 1973.
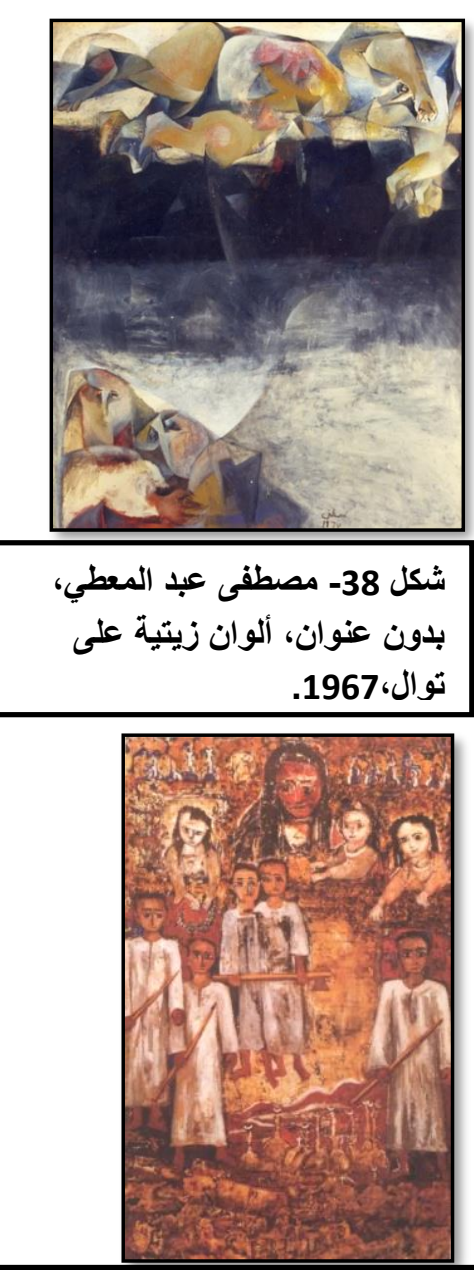

شكل 41- تحيه حليم، هذة الأرض لنا، ألوان زيتية على خشب،1969. 

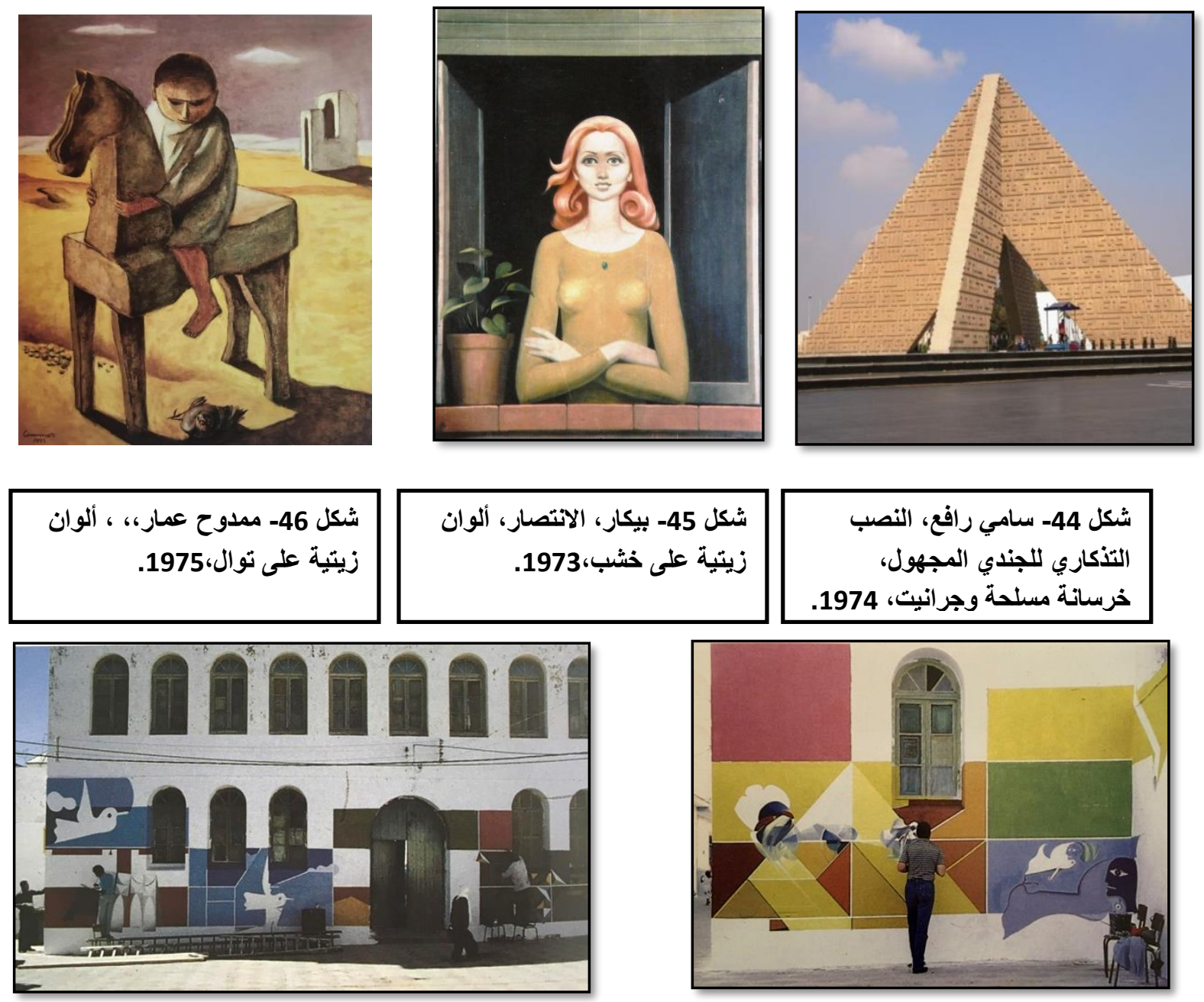

خرساتة مسلحة وجرانيث، 1974.

شكل 46- جماعة المحور، لقطات فوتوغرافية للعرض الثالث، تجهيز في الفراغ خارجي، منتصف الثمانينيات.

ثثمانينيات:

كان تأثير تيار الدداثة على الساحة الثقافية قد بأ منذ الأربعينيات كما جاء من قبل، ثم أطلت علينا اتجاهات فنون مابعد الحداثة بعد منذ منتصف السبعينيات مع التحول الانفتاحي والتأثر بأفكار المعسكر الغربي الرأسمالي (الولايات المتحدة وحلفائها) وتوجهاته المعلنة نحو مزيد من الحرية والتعبير عن الذات وعن المجموع (الفن الجماهيري) والمزيد من الفن الدعائي الاستهلاكي الذي يحتفي بالتجارب المتنوعة وأحداث الحياة اليومية، وهي مرحلة فاصلة بين فنون الحداثة ومابعدها في الغرب الغي

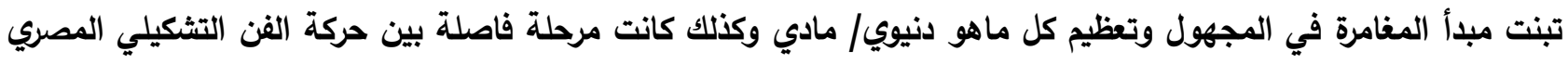

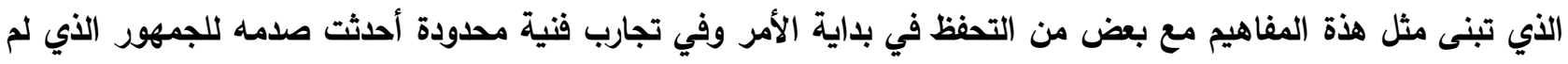
يكن بعد مهيئ لاستيعاب تلك التوجهات الجديدة. كان لهذا الانفتاح على العالم الخارجي أثر إيجابي على حركة الفن الفن التثكيلي عامة وآخر سلبي فاستطاع عدد من الفنانين المزج بين الاساليب الفنية الجديدة والخصوصية الحضارية المصرية، وتبني روح التجديد والابتكار، بينما غاص البعض الأخر في دوامة الثكلية والتقليد الخالي من المضمون. وقد كان لهجرة عدد من الفنانين

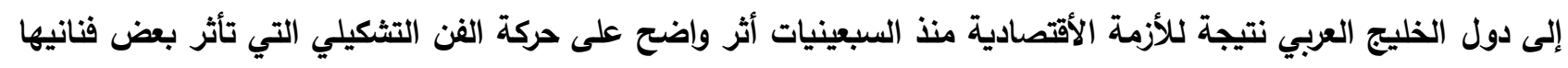
بالثقافة والموروث العربي المحافظ واتجه عدد منهم إلى التجريد الشكلي وتوظيف العناصر الزخرفية للفن الاسلامي في أعمال زخرفية أكثر منها فنية و الميل إلى معارضة الاتجاهات الغزبية من منظور أصولي ضيق. 
"خمدت الجذوة التي تلقفها جيل الستينيات مشتعلة ممن سبقوهم ليسلموها إلى جيل الثمانينات وقد استحالت رقعة تداخل فيها

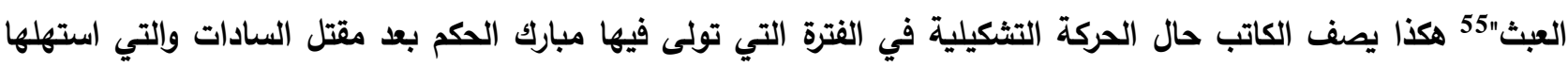
بالمصالحة العربية والمهادنه مع كافة التوجهات السياسية، وتولي في حكومته الثانية فنان تثكيلي حقيبة وزارة الثقافة مما كان له أثر كبير على التوجه الثقافي حتى نهاية القرن العشرين ويمكنتا القول أن حقبة الثمانينيات وبداية التسعينيات كانت فترة المخاض الثاني التي مهدت لاخول الفن التثكيلي المصري مرحلة مابعد الحداثة وانفتاحة على الثقافات المغايرة وعالم الآخر بثقة وثبات مكنته من حفر مكانة دولية في المجال إلا أنها مازالت إلى حد كبير تحت مظلة الرعاية الحكومية المتمثلة

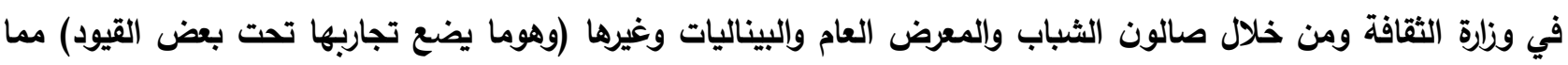

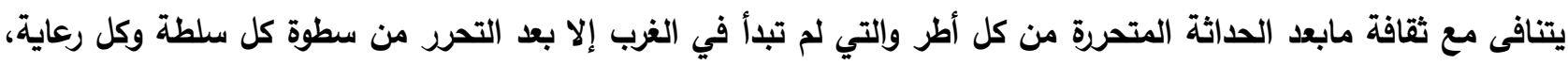
تلك المرحلة التي تأمل الباحثة في تناولها في بحث آخر قادم نظراً لاختلافها كلياً عن كل ماسبق. إن أكثر ما ميز فترة بداية الثمانينيات هو نشاط جماعة المحود التي تكونت عام 1981 آخر الجماعات الفنية في الحركة التثكيلية وتعتبر حلقة الاتصال بين فنون الحداثة المصرية ومابعدها. ضمت الجماعة أربعة فنانين من طليعة التنويرين

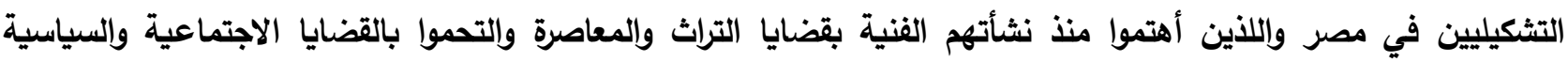
وبنبض الثارع المصري وقدمت أول إنشاء في الفراغ في تاريخ الحركة التشكيلية المصرية وهي مبادرة جريئة ندو كسر القيود

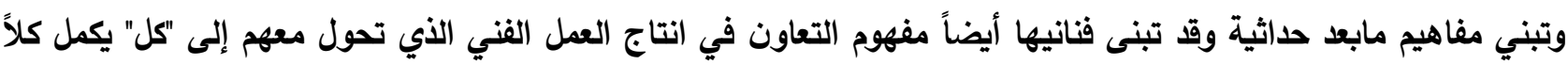

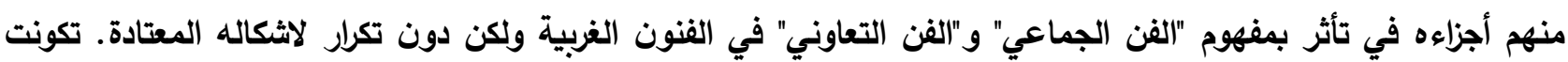

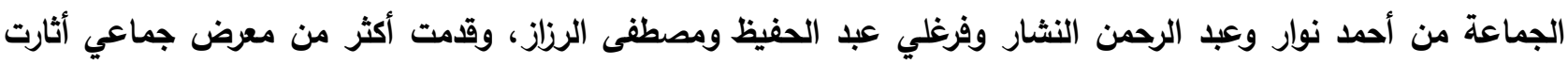

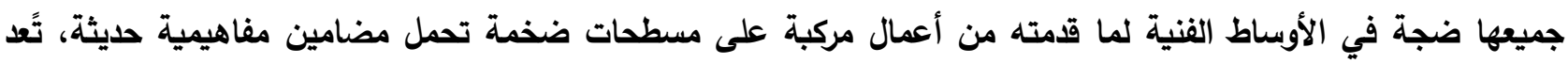

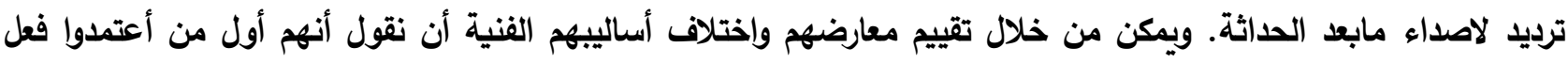

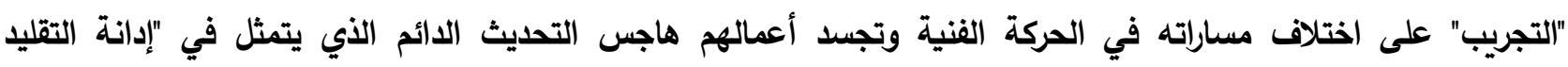
والمحاكاة ورفض النسج على منوال الأقدمين، والتوكيد على التفرد والسبق وعلى الابتكار" 56 وكذلك طرح رؤى وأساليب تجريبية

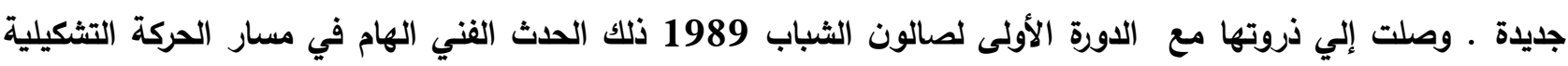
المصرية والاني ستبدأ معه مرحلة جديدة يمكننا أن نطلق عنها مابعد حداثية. إن ماقدمته جماعة المحور لا يقف فقط عند المسألة الجمالية وإنما يتعداها إلى شحذ طاقات التمرد على الأطر المرجعية ولكن دون الاخول في متاهات التغريب، فهي تجريبية إنتقائية إن جاز التعبير، تنتقي عناصرها من الموروث الحضاري وتقدمها لتها ضمن معالجات جديدة مفهومية حداثية، أو قل مابعد حداثية، حيث تداخلت فيها مبادئ ومفاهيم المرحلتين ولذلك تعدها الباحثة

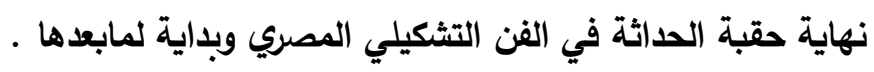
قدمت الجماعة أكثر من معرض في دول مختلفة وأرفقوا بمعارضهح بيانات مكتوبة تشرح الفكرة من تأسيس الجماعة وأهدافها واشتتركوا مجتمعين في تنفيذ الأعمال الفنية ذات حجم كبير بوسائط متعدد مع التجهيز في الفراغ. الخاتمة :

الفن هو مرآة العصر التى تنعكس فيها قيم وعادات ونشاط وتاريخ المجتمع الذي نثأ فيه ورغم أن "العمل الفني الحق -كما يقول الناقد عز الدين نجيب- يتجاوز أي إطار نظري أو منهجي، لأنه كائن حي متحرك ومتعدد الأبعاد وإلالالات والمؤثرات

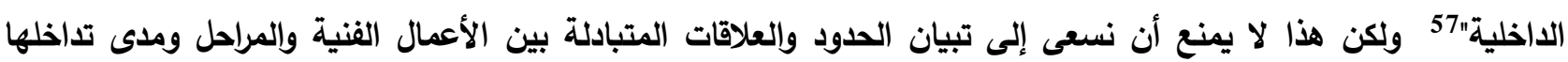

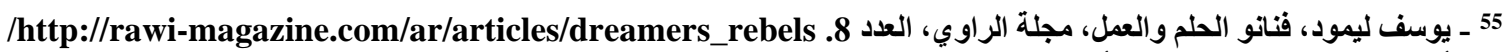

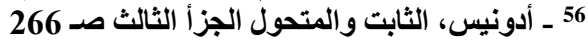
57 ـ هبة عزت الهونيس، الثري، تحولات التشكيل المصري الثعاصر (1967 - 2011)، دراسة، سلسلة الكتاب الأول 138 ،المجلس الأعلى للثقافة، 2015، ص 
ولذلك فإن الفصل بين الخطاب الثقافي العالمي وحركة الفن في مصر في القرن العشرين - أعني خطاب الحداثة وما بعدهابدعوى اختلاف الواقع التاريخي والمناخ العام، هو فصل جائر، إلا انه في ذات الوقتى، الربط بينهما والحماس والترويج لفكرة أنهما على قدم المساواة هو أيضاً مقولة تتسم بالمبالغة، فنحن شعوب لم تنتج حداثتها بالمعى الغربي وإنما فُرضتها الوقائع

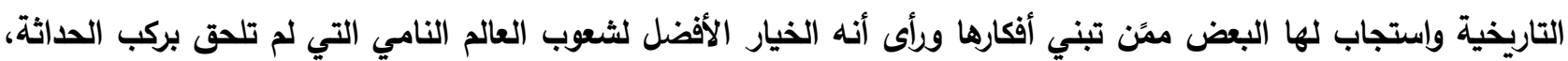
للتأكيد على حتمية اللحاق بركب الحضارة العالمي الذي أصبح واقع محلي - عالمي Glocal على حد تعبير ايهاب حسن ولوجوب التفاعل معه والاستفادة من تجاربه لكي نعبرعن أنفسنا وعن تجاربنا الذاتية من خلال إدراكنا للعالم المتفير من حولنا. النتائج والتوصيات: - 2 - 2

رغم الانجازات التي حدثت على طريق الحداثة ومابعدها في الثأن الفني كما جاء سابقاً "لم تستطيع الثقافة التثكيلية أن

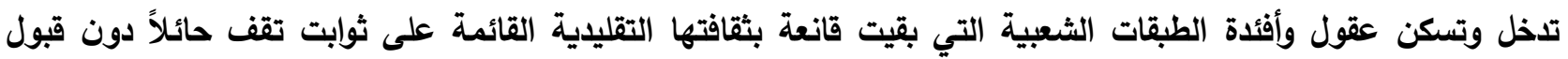

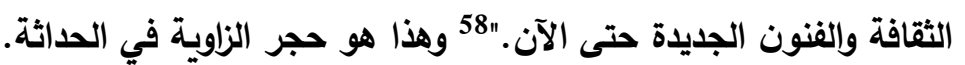
حالة الجمود في العلاقة بين الفنان والمتلقى تعني عدم تحقيق فعل التحديث لغايته حتى الآن وتعنى أيضاً أن حداثتنا هي حداثة (شكلية- محدودة) وليست حداثة جوهرية حضارية بالمدلول التأريخي لها حيث لم تمكن بالقدر الكافي لنقلة إيجابية في حجم الوعي والادراك في المجتمع ككل. قلة عدد المتابعين للمعارض الفنية من جمهور العامة الغير متخصص والصورة الذهنية السلبية التي صبغتها السنيما

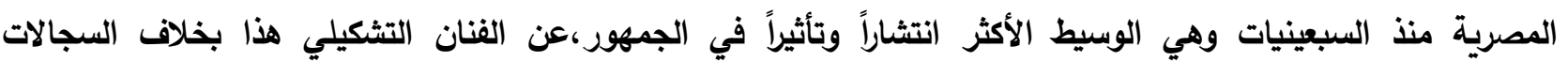
والمناقثات التهكية التي نتابعها على فترات متقاربة على وسائل التواصل الاجتماعي والتي تتناول أعمال الحركة التثكيلية التئية

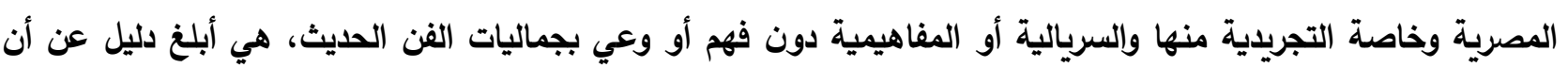

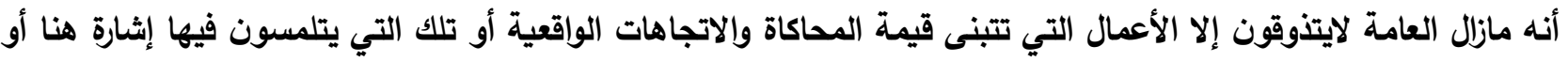

هناك عما يألفونه من عناصر وعلاقات مرتبطة بالواقع.

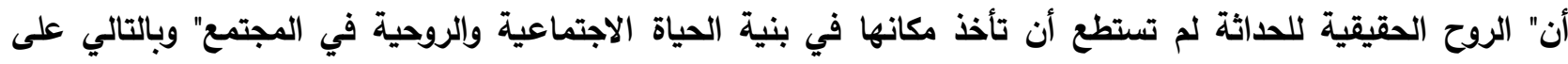
الجمهور المتلقي، على الرغم من تحققها في بعض المجالات ومنها الفن التشكيلي بالطبع، وكذلك شتى مناحي الفنون والثقافة، التي تفاعلت بوعي مع الحداثة ومارستها وتقف الآن على مشارف مابعدها مستبقة بذلك المجالات الأخرى. أن الحداثة في الفن التثكيلي المصري قد بدأت مواكبة لتيار الحداثة في الفن الغربي واستمرت حتى الثمانينيات ولم تنحى إلى ماتى جانب الأثكال والأساليب الجديدة لمرحلة مابعد الحداثة إلا في نهاية القرن العشرين، أي بعد نشأتها في الغرب بحان بحوالي

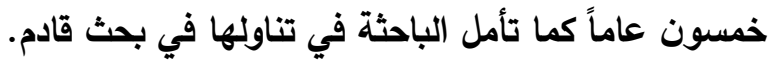
وهكذا نستطيع ان نقول أن الحداثة قد تحققت شكلاً ومضموناً في الحركة التشكيلية المصرية والدوائر الثقافية عموماً إلا إنها ثمثل حلقة مقطوعة في السلسة الثقافية والفكرية بثكل عام ونحن إذا أردنا لها الاتصال، يجب علئ علينا أولاً كمجتمع وأفراد البداء في نقد المفاهيم القديمة المتوارثة والتخلص من سطوتها والبعد عن الأساليب الجامدة في الرصد والتحليل وكذلك الأثثكال الثابتة في التعبير وتطبيق هذا على صعيد العلم والفكر والفن سواء بسواء، بالإضافة إلى الانفتاح على العالم انفتاحاً واعياً

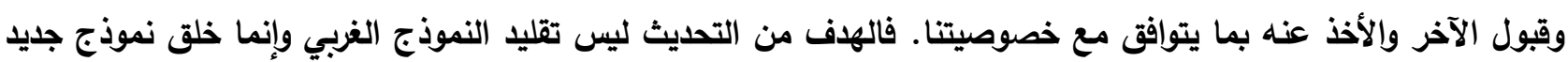
حديث يتوافق مع خصوصيتنا الحضارية قادر على النمو والتطور والتثبب إلى كافة مناحي الحياة وبالتالي التأثير في جودئه على كافة الأصعدة بثكل متكامل. 
1. عبد المقصود هيكل أحمد، تطور الأدب الحديث في مصر، دار المعارف، الجزء الأول، الطبعة السادسة، 1994.

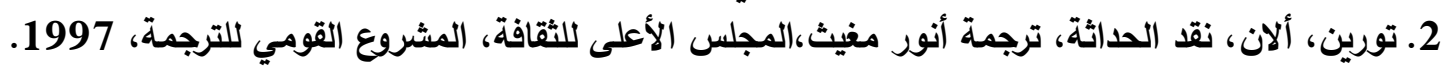

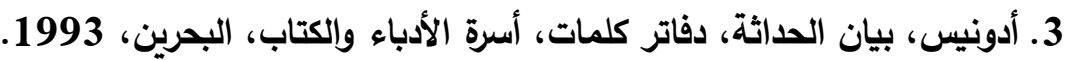
4. أدونيس، الثابت والمتحول، بحث في الإبداع والأتباع عند العرب، الجزء الأول، 1- الأصول، دار الساقي، نسخة البهة إليكترونية، 2006.

5. أدونيس، الثابت والمتحول، بحث في الإبداع والأتباع عند العرب، الجزء الرابع، 17- صدمة الحداثة وسلطة الموروث

$$
\text { الثعري، دار الساقي، نسخة إليكترونية، } 2006 .
$$

6. آزار،إيميه، التصوير الحديث في مصر حتى عام 1961، ترجمة إدوارد الخراط و نعيم عطية، المجلس الأعلى للثقافة، الثيكرونه،

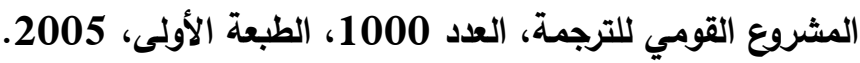

7. حسني،إيناس، جماعة الفن المعاصر ثروة باقية من الفن الجميل، سلسلة كتب بريزم للفن، وزارة الثقافة، العلاقات الثقافية الخارجية، مصر، 2009.

8. مارشال،برندا، تعليم مابعد الحداثة، المتخيل والنظرية، ترجمة وتقديم: السيد إمام، المشروع القومي للترجمة،1424،

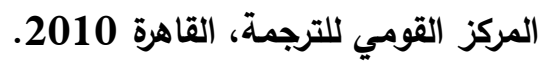

9. البغدادي، خالد، تجاذبات الصورة والنص في الفن المصري المعاصر، الهيئة المصرية العامة للكتاب، 2013. 10. رضا عبد السلام، فنانون مصريون بين الأصالة والحداثة، سلسة آفاق الفن التثكيلي، الهيئة العامة لقصور الثقابة الثقافة، مصر 2015.

11.

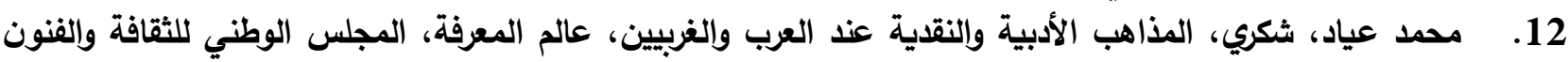

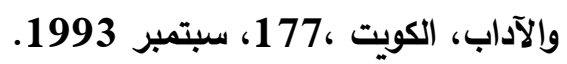

13. نجيب، عز الدين، فنانون وشهاء 1000، الفن التشكيلي وحقوق الانسان، مركز القاهلرة لدراسات حقوق الانسان 3، القاهرة

14.

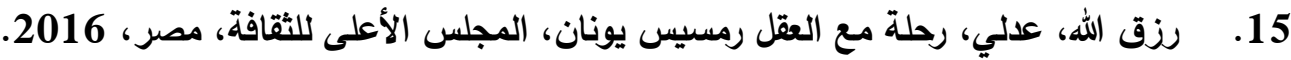
16. برينتون، كرين، تثكيل العقل الحديث، ترجمة شوقي جلال،مراجعة صدقي حطاب،عالم المعرفة، المجلس الوطني

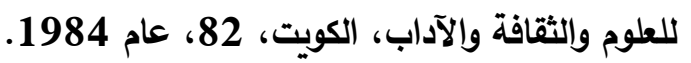

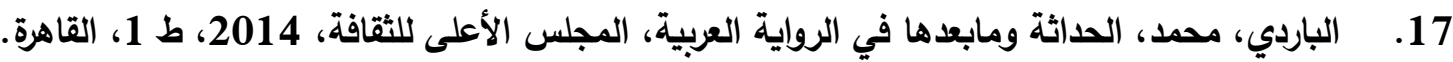
18.

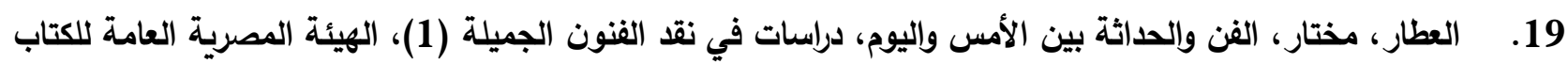

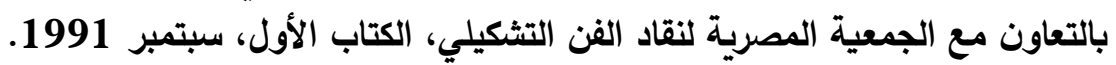

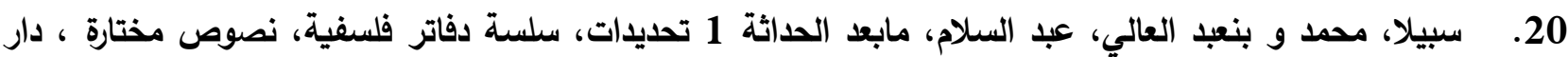

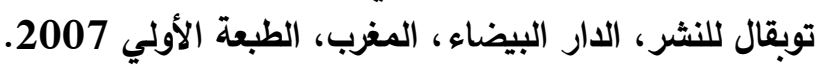

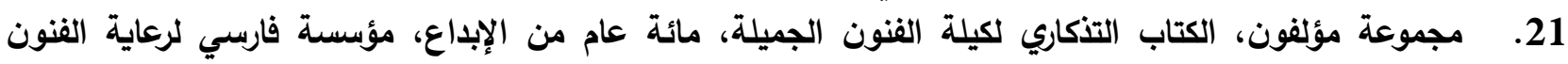
الوثقافة، 2008، مجوعه القاهرة.

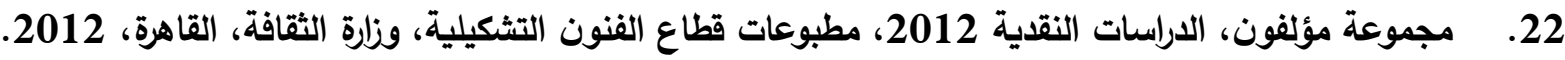
23. العطار، مختار، الفنون التثكيلية في مصر... إلى أين، دراسات في نقد الفنون الجميلة، الهيئة المصرية العامة للكتاب، 1999.

24. الخفيف، محمود، فصل في تاريخ الثورة العرابية، مؤسسة هنداوي للتعليم والثقافة، 2012. 
25. عطية، نعيم، المكان في فن التصوير المصري الحديث،دراسات في نقد الفنون الجميلة (4) الهيئة المصرية العامة

للكتاب بالتعاون مع الجمعية المصرية لنقاد الفن التشكيلي،

26. عزت حافظ، هبه، وآخرون، الحركة الفنية التشكيلية المصرية (الستينيات والسبعينيات) ثلاثة دراسات، المجلس

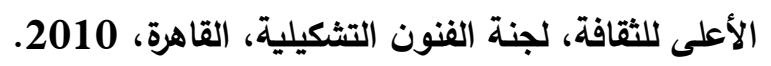

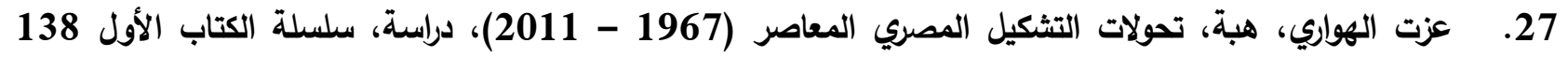

، المجلس الأعلى للثقافة، 2015.

28. هند الصوفي، الاتجاهات التصويرية في العالم الغربي والعربي منذ عصر النهضة وحتى الألف الثالث 1500 15015

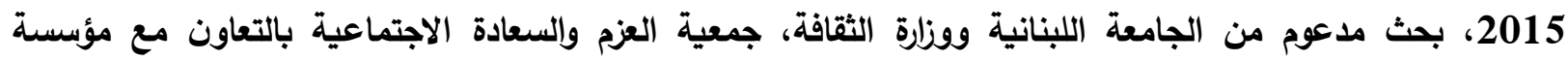

$$
\text { الصفدي، } 2015 .
$$

29. حقي، يحيى، في محراب الفن (موسيقي- تثكيل-عمارة) نهضة مصر للطباعة والنشر والتوزيع، 2008.

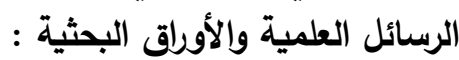

1. عاصم عبد الحق، ريم، فنون مابعد الحداثة في الغرب- النثأة والتطور، بحث منشور، المجلة العلمية للجمعية

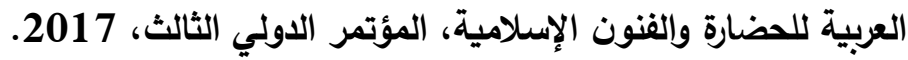

2. زيطة، منصور، مصطلح الحداثة عند أدونيس، رسالة ماجستير، كلية الآداب واللغات، جامعة قاصدي مرباح رقلة، الجزائر 2012 / 2013.

3. عبد السلام هلال، محمد، الفنانون الاجانب المعاصرون وأثرهم على الحركة الفنية في مصر، رسالة دكتوراة بحث غير

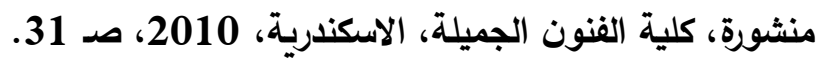

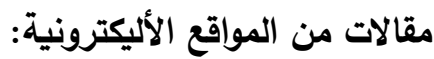
1- سعد الاين كليب، النقد ونثأة الحداثة، مقال، مدونة الحداثة وما بعد بعد الحداثة، مارس 2017. https://post2modernisme.blogspot.com.eg/2017_03_01_archive.html?view=classic 2- إيهاب حسن، أدب الصمت، ترجمة: محمد عيد إبراهيم، مدونة جورج باتاي، مارس 2015. http://nomene.blogspot.com.eg/2015/03/blog-post.html 3- عصمت داوستاشي، مجلات الفن التشكيلي في مصر، مشروع مُحبط، أخبار الأدب، نوفمبر/ 2015. http://www.dar.akhbarelyom.com/issuse/detailze.asp?mag=a\&field=news\&id=10877 4 سيد هويدي، سقوط الجماعات في مصر: روح الفريق وسبل المشاركة في العمل -قيم غائبة ج 2، مارس، 2016 ـ http://elsada.net/5838

http://nasser.bibalex.org/Speeches/browser.aspx?SID=1015\&lang=ar 5- وثيقة|لميثاق.

المراجع الأجنبية :

1- Ali, Wijdan, Contemporary Art from the Islamic World, Scorpion Publishing Ltd, London, on behalf of The Royal of Fine Arts, Amman, 1989.

2- Ismail, Fatma, 29 Artists in The Museum of Egyptian Modern Art, AICA, National Section of Egypt.

3- Karnouk, Liliane, Contemporary Egyptian Art, The American Universty in Cairo Press, 1995. 